Estudios sobre armas antiguas, arte militar $\mathrm{y}$ vida cultural en oriente y occidente

XL (2020), pp. 19-72

ISSN: 0436-029X; eISSN: 1988-4168

https://doi.org/10.3989/gladius.2020.02

\title{
EL ARMAMENTO DE ÉPOCA IBERORROMANA DE LIBISOSA (LEZUZA, ALBACETE). UN CONJUNTO EXCEPCIONAL*
}

\author{
THE IBERO-ROMAN PERIOD WEAPONS FROM LIBISOSA \\ (LEZUZA, ALBACETE, SPAIN). AN EXCEPTIONAL SET
}

\author{
POR \\ Fernando Quesada Sanz ${ }^{* *}$ y Héctor Uroz RodríGuez ${ }^{* * *}$
}

\section{RESUMEN - ABstract}

Las excavaciones que se vienen desarrollando en la ciudad de Libisosa (Lezuza, Albacete) han proporcionado - y siguen haciéndolo - un gran número de armas datables sobre todo en dos fases concretas: el periodo de estabilización de la conquista romana en el tercer cuarto del s. II a. C. y el periodo sertoriano, hacia el año 75 a. C. Este conjunto es muy notable por su número, la buena calidad de conservación, la variedad tipológica (ofensivas y defensivas de diversos tipos, arreos de caballo), y su preciso contexto arqueológico urbano. Para el periodo que conocemos como "baja época ibérica", que desde la otra perspectiva corresponde al periodo romano republicano en Hispania, el lote de armas de Lezuza es uno de los más completos e importantes de la península ibérica, por su relevancia y calidad al nivel de los de Numancia, Caminreal u Osuna.

Current archaeological excavations at the ancient city of Libisosa (Lezuza, Albacete, South-Eastern Spain) have yielded-and still do-a large number of weapons. These belong mostly to two different periods: the period of the stabilization of the Roman Conquest in the third quarter of the second century BC and the Sertorian Wars (c. 75 $\mathrm{BC}$ ). This assemblage is most relevant due to its size, good state of preservation, typological variety (a good sample of offensive and defensive weapons and horse tack), and its precise, urban archaeological context. For this period, both "Late Iron Age Iberian" or "Republican Roman" according to perspective, the weapons from Libisosa are one of the most important assemblages in the Peninsula, in a level with those from Numantia, Caminreal or Osuna.

\section{Palabras Clave - Keywords}

Armas antiguas; República romana; cultura ibérica; guerra.

Ancient weapons; Roman Republic; Iberian Iron Age; warfare.

\section{Cómo CITAR ESTE ARTículo / Citation}

Quesada Sanz, F. y Uroz Rodríguez, H. (2020): «El armamento de época iberorromana de Libisosa (Lezuza, Albacete). Un conjunto excepcional». Gladius, 40: 19-72. https://doi.org/10.3989/gladius.2020.02

* Trabajo realizado en el marco del Proyecto de Investigación del Plan Nacional HAR 2017-82806-P, "Ciudades y complejos aristocráticos ibéricos en la conquista romana de la Alta Andalucía"; y de "Investigación del Patrimonio arqueológico de Libisosa 2019" de los Proyectos de Investigación del Patrimonio Arqueológico y Paleontológico de Castilla-La Mancha para el año 2019 (DOCM n 103, de 29/05/2019).

** Universidad Autónoma de Madrid, Dpto. Prehistoria y Arqueología, fernando.quesada@uam.es / ORCID iD: http:// orcid.org/0000-0001-8664-0989

${ }^{* * *}$ Universidad de Murcia, Dpto. Prehistoria, Arqueología, Historia Antigua, Historia Medieval y Ciencias y Técnicas Historiográficas, hector.uroz@um.es / ORCID iD: http://orcid.org/0000-0002-0140-1071 


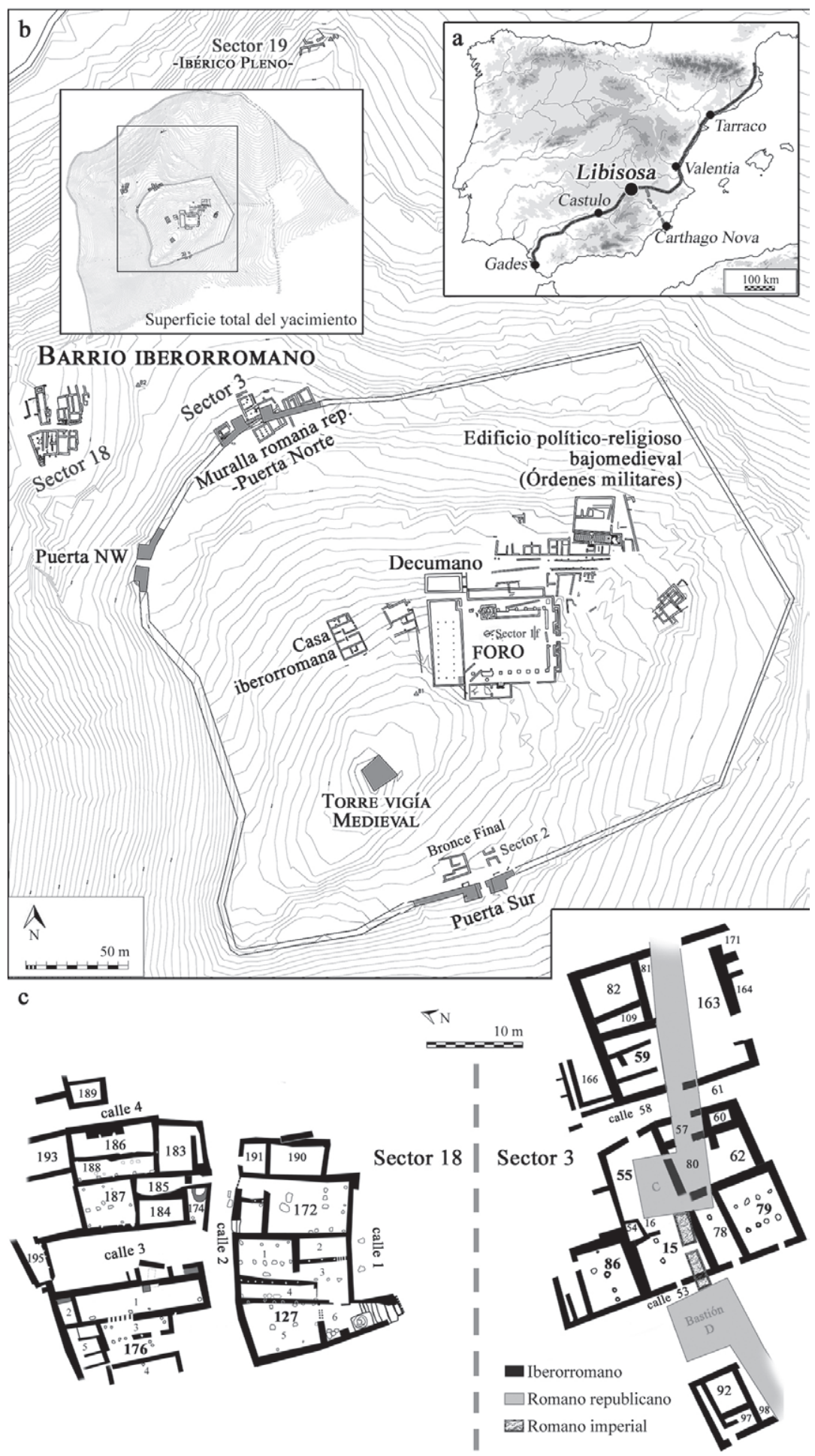

Figura 1. a. Mapa con ubicación de Libisosa; b. superficie del área arqueológica y topografía de los sectores excavados; c. planimetría del barrio iberorromano (Sectores 3 y 18). Elaboración: Héctor Uroz, a partir de levantamiento topográfico de Juan Antonio Tolosa y Jesús Cruz García (Diputación de Albacete) y fotogrametría de José Luis Fuentes (Oppida S.L.). 


\section{INTRODUCCIÓN: LIBISOSA Y SUS CONTEXTOS CERRADOS IBERORROMANOS}

Las excavaciones llevadas a cabo en el yacimiento del Cerro del Castillo del municipio de Lezuza (Albacete) (Fig. 1a-b) en las últimas décadas ${ }^{1}$ han sacado a la luz un conjunto arqueológico que abarca unas 30 ha (Fig. 1b), y confirman las noticias de las fuentes literarias sobre la existencia de un oppidum ibérico oretano (Ptolomeo, Geog. II, 6, 58), y una colonia augustea con ius italicum (Plinio, HN III, 25) ${ }^{2}$. A su vez, Libisosa conserva restos que se remontan al Bronce Final (Uroz Rodríguez, e. p. a: 17-21) y alcanzan la Baja Edad Media (Uroz Sáez et alii, 2004: 190-191), si bien con algunos hiatos, siendo el más acusado el paréntesis de época tardoantigua y altomedieval.

De la etapa ibérica de Libisosa encontramos restos dispersos y parciales del Ibérico Antiguo y Pleno (Uroz Rodríguez, e. p. a: 21-34) que dan cuenta de la relevancia del enclave en la Protohistoria de la zona. Pero es su fase iberorromana (siglo II - primer cuarto del I a. C.), a la que corresponden el armamento y elementos de monta que presentamos en este trabajo, la que destaca como una fuente de información privilegiada sobre la cultura ibérica final y la romana republicana en Hispania, debido a una excelente conservación de sus estructuras y materiales por su destrucción precipitada y sistemática, generando un "efecto sepultura" que constituye en la práctica un contexto cerrado en sí mismo. En virtud de la cronología aportada por el contundente registro material documentado, que incluye tanto ánforas (Dr 1, Lamb. 2, brindisinas, norteafricanas), como producciones tardías de cerámica de barniz negro (principalmente de Cales), imitaciones locales, paredes finas, producciones de Asia Menor y un numeroso conjunto de vajilla de bronce romana (Hernández, 2008; Uroz Rodríguez, 2015; Uroz Rodríguez et alii, e. p. a y e. p. b), implementado por algún hallazgo de restos humanos con muerte violenta (De Miguel y Uroz Rodríguez, 2017) y actuación ritual puntual (Uroz Rodríguez, 2012), hemos relacionado este episodio con las guerras sertorianas acontecidas a gran escala en la península ibérica entre los años 82 y 72 a. C. (Uroz Rodríguez y Uroz Sáez, 2014), posiblemente con el paso del ejército en la toma de Valentia, ciudad que también ha proporcionado un interesante lote de armamento republicano (Alapont et alii, 2010; Ribera, $1995 ; 2013 ; 2014)$.

Más allá de la cultura material mueble, elevada en términos absolutos pero minoritaria en detrimento de lo ibérico, Roma no dejó huella estructural en Lezuza hasta la construcción de la muralla ${ }^{3}$, erigida seguramente por el mismo destacamento romano inmediatamente después de la destrucción definitiva del oppidum. Hasta entonces, este poblado, sede de la oligarquía local y su clientela, habría permanecido en régimen de deditio in fidem, como el común de comunidades indígenas que no desaparecieron al principio de la conquista (Uroz Sáez, 2012: 93-96). Mantendría su ordenamiento social a cambio de perder la propiedad de la tierra y un estipendio, y lo haría beneficiada por su situación geoestratégica, pues controlaba el paso del Sur al Levante peninsular (Uroz Sáez y Uroz Rodríguez, 2016) (Fig. 1a), con los contactos comerciales y políticos que ello ofrecía, y que habría favorecido desde muy temprano su proceso de (auto)romanización.

1 Las actuaciones arqueológicas en Libisosa, dirigidas por Héctor Uroz Rodríguez junto a José Uroz Sáez y José Antonio Molina Gómez, se desarrollan al amparo de los proyectos de investigación y los programas de intervención sistemática del Servicio de Arqueología y Patrimonio de la Consejería de Cultura de Castilla-La Mancha, con la colaboración del Ayuntamiento de Lezuza, la Diputación Provincial de Albacete-Instituto de Estudios Albacetenses, la Universidad de Alicante y la Universidad de Murcia.

2 Para una síntesis histórico-arqueológica de la evolución de Libisosa, con especial hincapié en la fase romana, véase: Uroz Sáez, 2012.

3 Sobre la muralla romana tardorrepublicana, véase: Uroz Sáez et alii, 2003 y 2006; Uroz Sáez, 2012: 101-103.

Gladius, XL (2020), pp. 19-72. ISSN: 0436-029X; eISSN: 1988-4168. https://doi.org/10.3989/gladius.2020.02 
De este período hemos descubierto si cabe la punta del iceberg, y hasta la fecha engloba dos sectores: el sector 3 (Fig. 1c), del que se han exhumado una veintena de departamentos plurifuncionales, de marcada isonomía en planta y sistema edilicio, sobre el que se levantaría en parte la puerta norte de la muralla romana (Uroz Rodríguez, e. p. a y e. p. b; Uroz Rodríguez, 2012: 242-248; Uroz Sáez et alii, 2003); y el sector 18 (Fig. 2), de mayor heterogeneidad, dominado por el departamento 127, un "edificio oligárquico" de grandes dimensiones $\left(181 \mathrm{~m}^{2}\right)$, donde se evidencia el ejercicio de los diversos procesos de producción (Uroz Rodríguez, 2012: 248-298) y al que se adosaría por el este una gran bodega (77 $\left.\mathrm{m}^{2}\right)$, el dpto. 172, para el control de los excedentes (Uroz Rodríguez, e. p. a: 80-85).

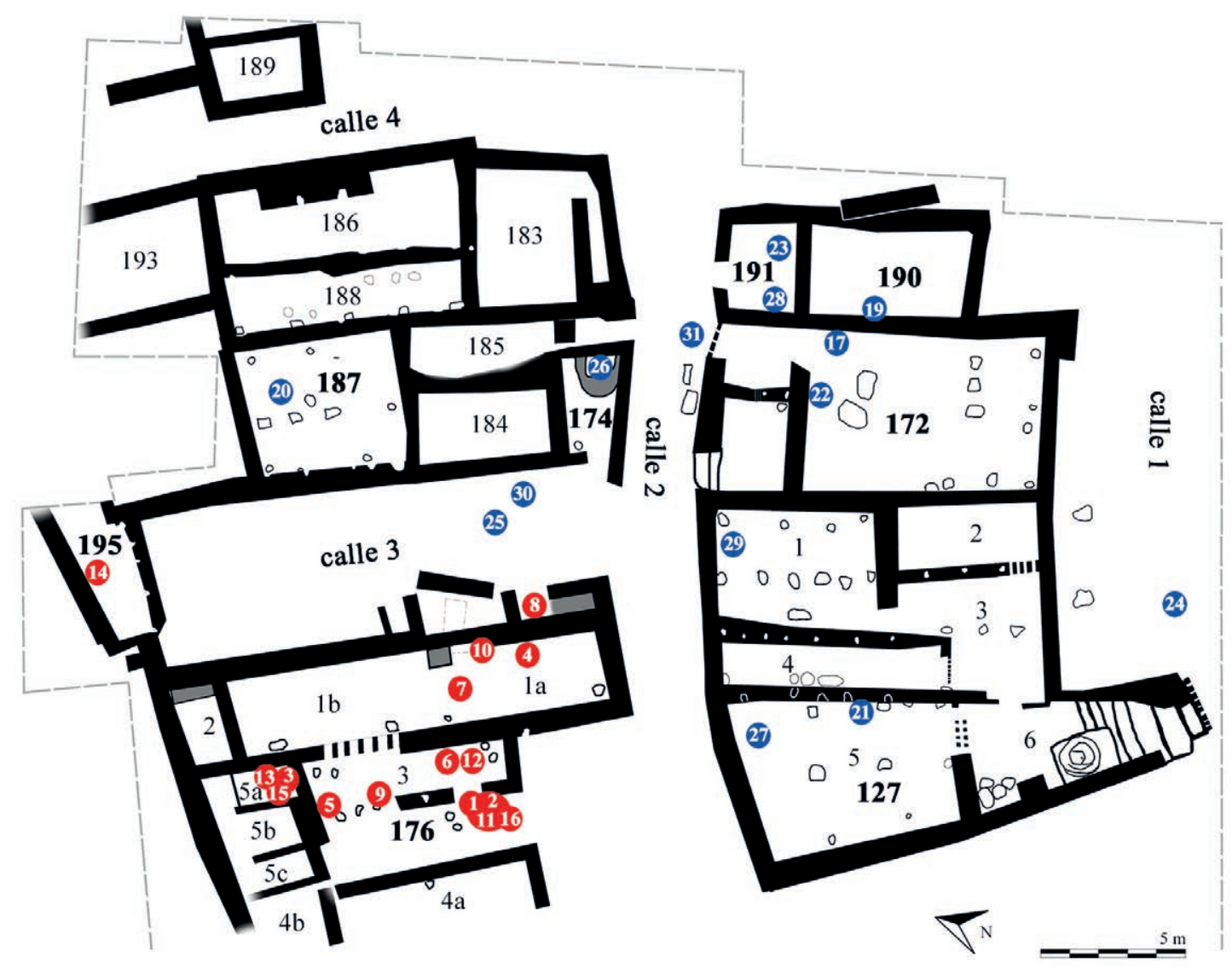

Figura 2. Planimetría del Sector 18 (actualizada a septiembre de 2019) con indicación de los hallazgos de armas y arreos (según numeración del catálogo). Elaboración: Héctor Uroz a partir de topografía y fotogrametría de José Luis Fuentes (Oppida S.L.).

La mayoría de las armas y arreos de caballo encontrados en Libisosa proceden del sector 18. Justamente es aquí donde se han centrado las excavaciones de la última década, que han sacado a la luz nuevos matices en diversas direcciones, incluyendo algunos contextos con una datación algo anterior para su destrucción. Es, sin duda, el caso del departamento 176, un complejo de $175 \mathrm{~m}^{2}$ con 5 ambientes, ubicado en el límite occidental de la explanada, separado del dpto. 127 por una calle, y que hemos definido, sobre todo por argumentos materiales, como lugar de culto gentilicio o dinástico (Uroz Rodríguez, 2018; 2020; e. p. a y e. p. b). Se trata, 
además, del edificio con mayor concentración de armamento hasta la fecha. Su datación en el 200-125 a. C. llega, una vez más, por un registro contundente, un nutrido conjunto de producciones de barniz negro mayoritariamente napolitanas de la fase antigua, con algunos ejemplares algo más arcaicos, testigos de un primer contacto de la aristocracia local con Roma, y que permanecerían vigentes junto a un mucho más reducido grupo de producciones calenas de una fase media inicial y de ánforas Dr. 1, que rebajaría la fecha del final del edificio al último cuarto del s. II a. C. (Uroz Rodríguez, e. p. a y e. p. b; Uroz Rodríguez et alii, e. p. b). Nos encontraríamos, por tanto, ante un nuevo contexto cerrado, destruido y cancelado de forma repentina décadas antes de la destrucción definitiva del poblado, ya fuese motivado por un cambio de régimen interno o bien por alguna intervención exógena puntual de la autoridad romana.

Así pues, con esta información juzgamos procedente separar la presentación y análisis de los dos grandes conjuntos por periodos, para observar si hay o no diferencias sustanciales entre ambos lotes. Dentro de cada uno seguiremos la presentación habitual distinguiendo las categorías funcionales y tipológicas de los objetos. ${ }^{4}$ Aunque se ha publicado alguna foto y descripción genérica de alguna de las armas aquí catalogadas, la inmensa mayoría son totalmente inéditas y las pocas piezas que ya han sido presentadas (fundamentalmente en Uroz Rodríguez y Uroz Sáez, 2014: 210; y Uroz Rodríguez, 2012: 288, 301) se estudian aquí en detalle por vez primera, individualmente y dentro del conjunto de la panoplia recuperada en Libisosa ${ }^{5}$.

\begin{tabular}{|c|c|c|c|c|c|c|c|c|c|c|c|c|c|}
\hline \multicolumn{14}{|c|}{ ARMAS Y ARREOS DE CABALLO HALLADAS EN LIBISOSA/LEZUZA HASTA 2019} \\
\hline \multicolumn{8}{|c|}{$\begin{array}{l}\text { OFENSIVO } \\
\text { s. II: } 7 \\
\text { s. I: } 7 \\
\text { Total: } 14\end{array}$} & \multicolumn{3}{|c|}{$\begin{array}{l}\text { DEFENSIVO } \\
\text { s. II: } 2 \\
\text { s. I: } 3 \\
\text { Total: } 5\end{array}$} & \multicolumn{3}{|c|}{$\begin{array}{c}\text { ARREO /MONTA } \\
\text { s. II: } 6 \\
\text { s. I: } 6 \\
\text { Total: } 13\end{array}$} \\
\hline \multicolumn{3}{|c|}{$\begin{array}{l}\text { EMPUÑ̃DO } \\
\text { s. II: } 5 \\
\text { s. I: } 1 \\
\text { Total: } 6\end{array}$} & \multicolumn{2}{|c|}{$\begin{array}{l}\text { ASTA } \\
\text { s. II: - } \\
\text { s. I: } 5 \\
\text { Total: } 5\end{array}$} & \multicolumn{3}{|c|}{$\begin{array}{l}\text { PROPULSADO } \\
\text { s. II: } 2 \\
\text { s. I: } 1 \\
\text { Total: } 3\end{array}$} & $\begin{array}{l}\text { ACTIVO } \\
\text { S. II: } 2 \\
\text { s. I: } 2 \\
\text { Total: } 4\end{array}$ & \multicolumn{2}{|c|}{$\begin{array}{l}\text { PASIVO } \\
\text { s. II: - } \\
\text { s. I: } 1 \\
\text { Total: } 1\end{array}$} & \begin{tabular}{|} 
MONTA \\
s. II: 6 \\
s. I: 1 \\
Total: 7
\end{tabular} & \multicolumn{2}{|c|}{$\begin{array}{l}\text { ARREO } \\
\text { s. II: } 1 \\
\text { s. I: } 5 \\
\text { Total:6 }\end{array}$} \\
\hline 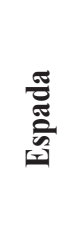 & 吾 & & 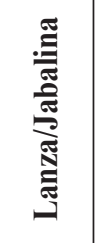 & $\stackrel{\Xi}{\Xi}$ & $\frac{\frac{\pi}{\tilde{E}}}{\frac{d}{I}}$ & 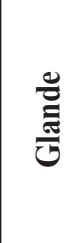 & 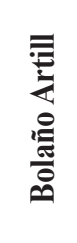 & 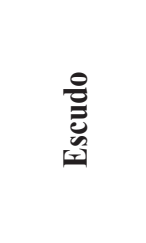 & 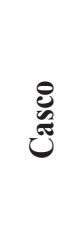 & 苞 & 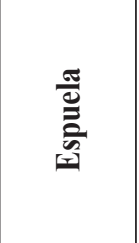 & 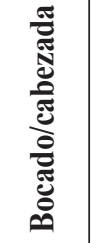 & $\frac{\frac{\pi}{2}}{\frac{\pi}{\pi}}$ \\
\hline $\begin{array}{l}\text { s. II:1 } \\
\text { s. I:1 }\end{array}$ & $\begin{array}{l}\text { s. II:2 } \\
\text { s. I:- }\end{array}$ & $\begin{array}{l}\text { s. III:2 } \\
\text { s. I:- }\end{array}$ & $\begin{array}{l}\text { s. II:- } \\
\text { s. I:2 }\end{array}$ & \begin{tabular}{|l|} 
s. II:- \\
s. I:3
\end{tabular} & $\begin{array}{l}\text { s. II:2 } \\
\text { s. I:- }\end{array}$ & $\begin{array}{l}\text { s. II:- } \\
\text { s. I:- }\end{array}$ & $\begin{array}{l}\text { s. II:- } \\
\text { s. I: } 1 ?\end{array}$ & $\begin{array}{l}\text { s. II:2 } \\
\text { s. I:2 }\end{array}$ & $\begin{array}{l}\text { s. II:- } \\
\text { s. I:1 }\end{array}$ & \begin{tabular}{|l} 
s. II:- \\
s. I:-
\end{tabular} & $\begin{array}{l}\text { s. II: } 6 \\
\text { s. I: } 1\end{array}$ & $\begin{array}{l}\text { s. II: } 1 \\
\text { s. I: } 2\end{array}$ & $\begin{array}{l}\text { s. II: } \\
\text { s. I: } 3\end{array}$ \\
\hline Total:2 & Total:2 & Total:2 & Total:2 & Total:3 & Total:2 & Total-: & Total:1 & Total:4 & Total:1 & |Total:- & Total:7 & Total: 3 & Total: 3 \\
\hline
\end{tabular}

4 Abreviaturas empleadas: N. Inv.: número de inventario; Lg. Mx.: longitud máxima ('c'o 'e' si es conservada o estimada respectivamente); Lg. Mx. (e): estimación de la longitud máxima original; Lg. Hj/P: longitud máxima de la hoja/punta si está completa; Lg. Mx. Hj/P (e) si hay que estimarla; An. Mx. Hj.: anchura máxima de la hoja; An. Bas.: anchura basal de la hoja (ancho máximo en la zona de la empuñadura, a menudo cubierta por las cachas); An. Ped.: ancho del pedúnculo; Gr. Mx. Hj.: grosor máximo de la hoja en nervio o arista si es a cuatro mesas; LIE: longitud interior de la empuñadura (define el espacio útil para palma de mano); Diam. asta: diámetro del asta (medio); Diam. Mx.: diámetro máximo; Lg. Cb.: longitud del cubo; Diam. Cb: diámetro del cubo; Gr. Cb.: grosor de la chapa del cubo.

5 Todos los dibujos han sido elaborados, como es habitual en las publicaciones del repertorio libisosano, por Nora Hernández Canchado, a quien agradecemos su disposición y saber hacer. 
CATÁLOGO RAZONADO. EL SIGLO II A. C.

\author{
Armamento ofensivo. Armas empuñadas
}

1. Espada. N. Inv. LB 152140. Sector 18. Dpto. 176-Estancia 3. Campaña 2017. Figs. 3a y 4a.

Espada de hoja recta en hierro forjado fragmentada en tres trozos.

Dimensiones: Lg. Mx. (completa): 74 cm; Lg. Hj.: 65 cm; An. Mx. Hj: 5,6 cm (hombros).

Muy exfoliada. Hoja de filos paralelos, muy ligeramente pistiliformes. Estaría pues a caballo entre el perfil semiparalelo y el pistiliforme de la clasificación de García Jiménez (2006: 119, fig. 34). Sin nervio, arista ni vaceos, hoja de sección lenticular con apenas una traza de cuatro mesas con luz rasante. Hombros de tendencia oblicua o "caída semirecta". Espiga de sección rectangular aplanada. Carece de pomo de botón (vid. García Jiménez, 2006: fig. 30). Sin elementos de vaina enteriza o de armazón.

Fue encontrada apoyada verticalmente contra una pared, lo que ha provocado una curvatura no intencionada de la hoja (Fig. 4a).

La ausencia de nervio en el eje de la hoja es una característica de fecha avanzada en este tipo de espadas derivadas de los modelos de la Tène I, que en Iberia alcanzaron larga perduración (Quesada, 1997b: 260 ss.), ya que el nervio tiende a desaparecer por completo a partir del siglo III a. C., convirtiéndose la sección lenticular en la más frecuente (Lejars, 2003: 24; García Jiménez, 2006). Si en efecto los hombros son asimétricos y no se trata de un problema de conservación, tendríamos una forma muy característica del s. II a. C., con un hombro oblicuo o caído y otro de tendencia semirrecta (García Jiménez, 2006: 122-124).

En conjunto, la espada entra cómodamente dentro del Grupo VII.C de Quesada y, con más precisión, en el Grupo D de García Jiménez, ya no limitado al NE peninsular (García Jiménez, 2012: 121). Es más difícil precisar tipo, dado el estado de conservación de la hoja, pero una vinculación con el Tipo D.1 de GJ es lo más probable ${ }^{6}$.

Por su parte, los $65 \mathrm{~cm}$ de hoja son una medida casi estándar con una horquilla de unos 7 $\mathrm{cm}$ entre 60 y 67, en hojas de este tipo habitualmente clasificadas como gladii hispanienses ( $c f$ Quesada, 1997a: 268, fig. 157). Así es el caso de espadas romanas "hispanienses" de los ss. II-I a. C., con longitudes de hoja de $60 ; 63,1 ; 63,7 ; 66,6 ; 67,5 \mathrm{~cm}$, todas ellas similares al tipo Quesada VIIC (1997a: 254 ss.).

En conjunto, pues, la fecha de mediados/tercer cuarto del s. II a. C. propuesta para el final del contexto arqueológico en el que apareció la espada es plenamente consistente con su tipología. Sus paralelos abarcan buena parte de la península, en contextos tanto iberos (Cabecico del Tesoro), como lusitanos (El Romazal), celtíberos (Quintanas de Gormaz, Atance), como posiblemente romanos (Azucarera), indicando la fuerte difusión de este tipo de espada en época ya avanzada.

A excepción de la espuela N. Inv. 152580, todo el armamento de este apartado ha sido recuperado en el mismo lugar, el complejo de culto (dpto. 176). La espada se asocia de forma directa en esta misma estancia 3 a uno de los puñales de tipo hispano (N. Inv. 152201), una parte de umbo de escudo bivalvo para un cuerpo de escudo oval (LB 150993), una punta de flecha (LB 151031), tres espuelas (LB 151092, 149940 y 152142) y un cuchillo (LB 152198). Estamos ante la habitación con más armas de todo el edificio, aunque en ningún caso se pueda hablar de "panoplia".

\footnotetext{
6 De hecho, consultado nuestro antiguo discípulo y ahora estimado colega y especialista, Dr. García Jiménez, sobre fotos y dibujo considera que, aunque la pieza podría eventualmente ubicarse en su tipo B.1, bastante antiguo, más probablemente es su derivación en su tipo D.1.
} 

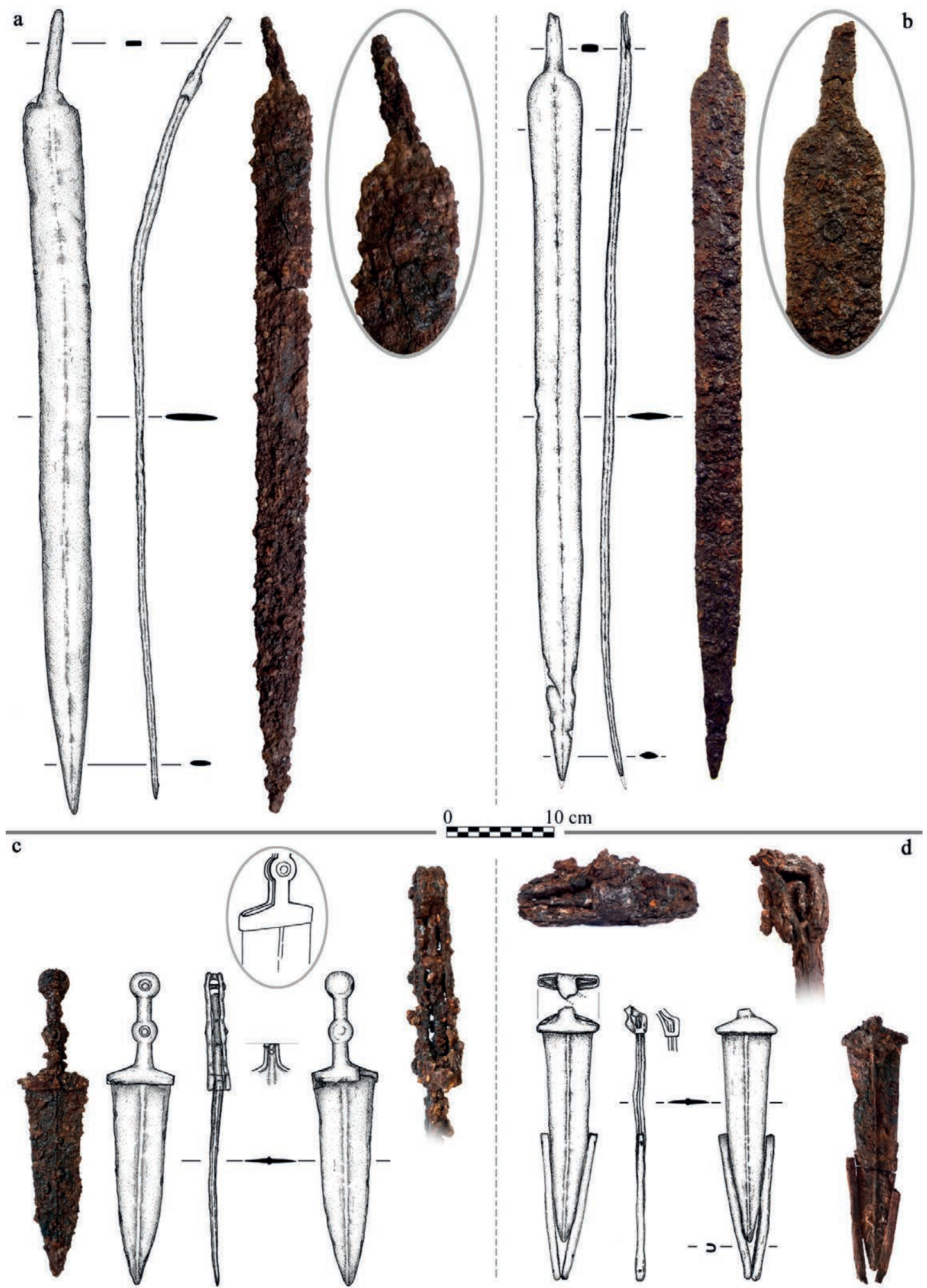

Figura 3. Armamento ofensivo. Armas empuñadas: a. espada LB 152140; b. espada LB 130597; c. puñal LB 152201; d. puñal LB 152382. Fotografías: Héctor Uroz. Dibujos: Nora Hernández. 

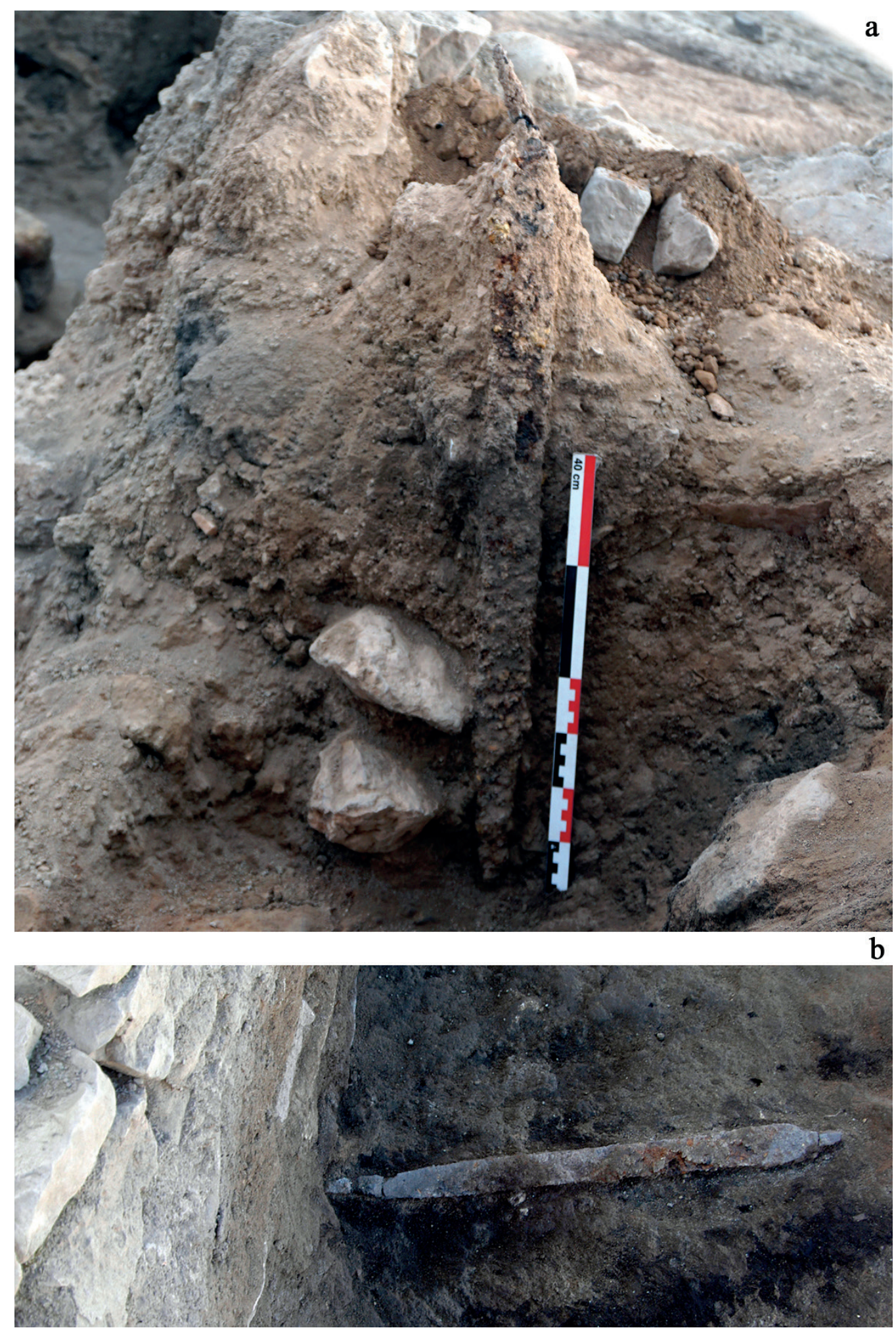

Figura 4. Imágenes del hallazgo de las espadas: a. LB 152140; b. LB 130597. Fotografías: Héctor Uroz. 


\section{Puñal. N. Inv. LB 152201. Sector 18. Dpto. 176-Estancia 3. Campaña 2017. Fig. 3c.}

Puñal completo en hierro, de empuñadura bidiscoidal mejor que biglobular, ya que los elementos de la empuñadura son planos (Kavanagh, 2008; Kavanagh y Quesada, 2009: 339). No se asocia a restos de vaina, que en principio sería de estructura de armadura de hierro con o sin placas decorativas de lámina de bronce, y que es uno de los mejores criterios para precisión tipológica y cronológica (Kavanagh y Quesada, 2009).

Dimensiones: Lg. Mx.: 29,3 cm; Lg. Hj.: 19,1 cm; LIE: 7 cm; An. Mx. Hj.: 5,5 cm; Gr. Mx. Hj.: 0,7 cm.

La estructura de la empuñadura se conserva prácticamente completa, lo que es inhabitual. Consta de una lengüeta o pletina plana prolongación forjada de la hoja, a la que se añadieron por ambos lados dos cachas de madera, delgadas (hoy perdidas), y sobre ellas sendas chapas metálicas recortadas en forma de " $\mathrm{T}$ " invertida, siendo el palo de la $\mathrm{T}$ la guarda. Los remaches que enlazan todos los elementos están reforzados en una de las caras por unas arandelas metálicas, también de hierro. La pieza, en mal estado, no deja ver si las cachas metálicas exteriores tenían la característica arista longitudinal que caracteriza puñales hispanos tardíos y que influyeron en los romanos, pero en todo caso la estructura no es la de un puñal de aristas y sí de pletina plana con discos concéntricos (Kavanagh, 2008: 26 ss. y figs. 3 y 4) (vid. infra) típica del s. II a. C. Los hombros de la guarda (arriaces) están abatidos, inclinados, lo que le proporciona una tendencia triangular (Modelo B de Kavanagh, 2008: 40-41, que aparece desde el s. III a. C. al I d. C.)

No se aprecian restos de decoración damasquinada y/o incisa, ni de elementos de aleación de cobre, habituales en piezas celtibéricas de los siglos III-II a. C.

La hoja no presenta la tendencia triangular de filos rectilíneos convergentes más frecuentes, ni tampoco tiene la tendencia ondulada y/o pistiliforme característica de las producciones meseteñas tardías (De Pablo, 2010; 2012; 2018) y las ya romanas de comienzos de época imperial en la península (Fernández, 2008: 107 ss. y passim). Es una hoja sólida pero basta y poco elegante, con filos de tendencia paralela en el tercio fuerte, y larga punta, con marcado nervio longitudinal y sólida punta. El ejemplar de Libisosa parece tener un nervio redondeado y no en arista o "esteliforme" (B de Kavanagh, 2008: 55-56). Si es así, es una rareza dado que la mayoría de los puñales hispanos tiene sección a cuatro mesas o lenticular. En todo caso, el tipo de hoja es en conjunto bastante frecuente en el s. II a. C. aunque hay ejemplos previos (Kavanagh, 2008: 51-52).

El tipo forma parte de la gran y variada familia de los puñales peninsulares. Es el grupo Quesada VI, el de desarrollo más tardío y con probable origen y dispersión predominante en la meseta oriental (Quesada 1997a: 280-218, Grupo VI, y 292 ss.) entre finales del s. IV y el s. III a. C. Esta familia pervive, con distintas variantes tipológicas, hasta el s. I a. C. Los 19,1 cm de longitud de hoja del ejemplar de Libisosa (LB 152201) encajan justamente en los valores modales del puñal bidiscoidal hispano, que tienen un muy gran recorrido entre 13 y $27 \mathrm{~cm}$, pero que en su mayor parte se agrupan, consistentemente entre los 17 y $20 \mathrm{~cm}$. No ocurre lo mismo con los 5,5 cm de anchura máxima de hoja, que está en la parte alta de la distribución (de 3 a $7 \mathrm{~cm}$, la mayoría en torno a los 4-4,4 cm, Kavanagh, 2008: fig. 15, p. 53) lo que proporciona un aspecto muy robusto a nuestra arma. ${ }^{7}$

7 Hemos consultado con nuestro colega E. Kavanagh, quien confirma plenamente nuestro diagnóstico añadiendo: «La hoja es "de base dilatada", que es también una de las formas más comunes, pero predominantemente indígena, no romana. Este tipo de hoja es típica del periodo 150-50 a. C. El pomo no es mucho más grande que el disco central, lo que suele ser signo de antigüedad (siglo II a. C.)». 

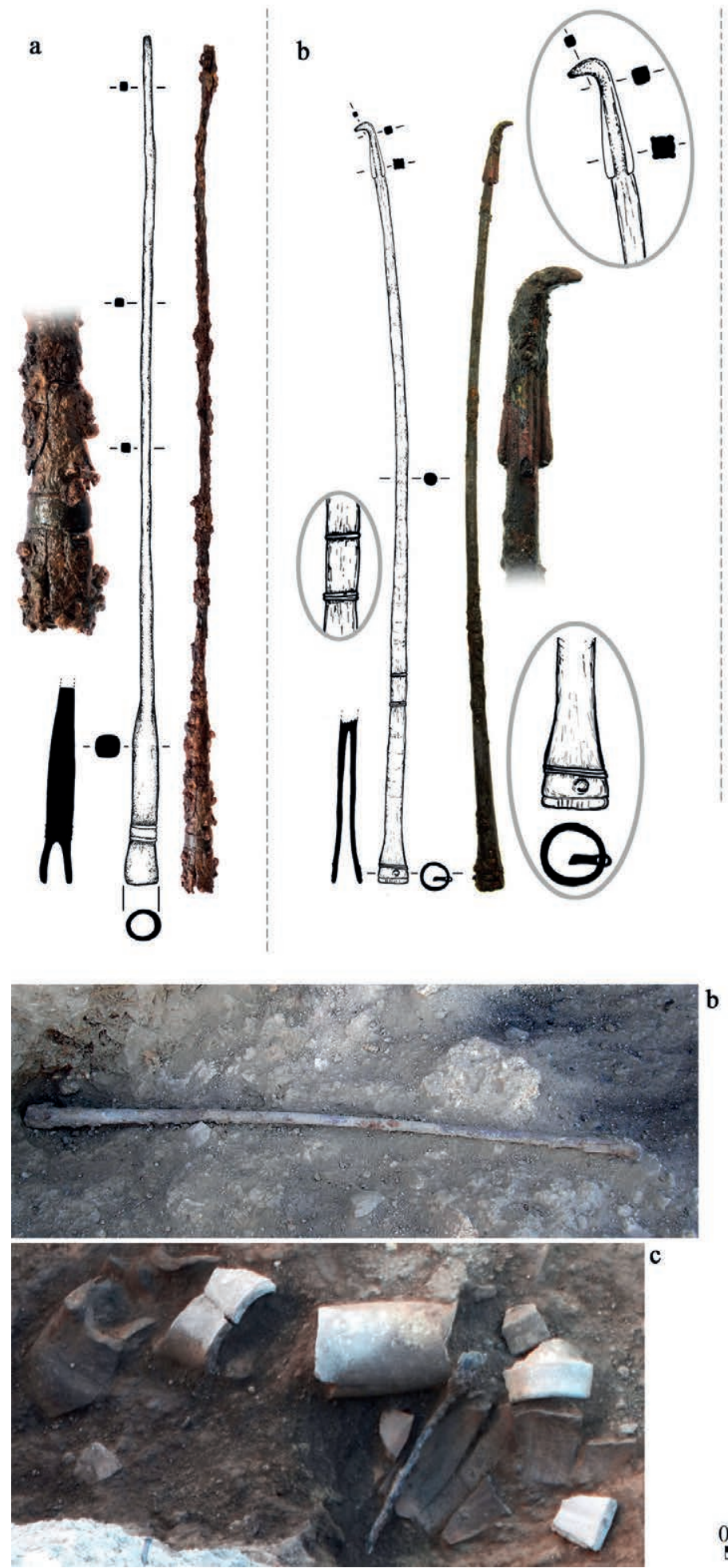

c

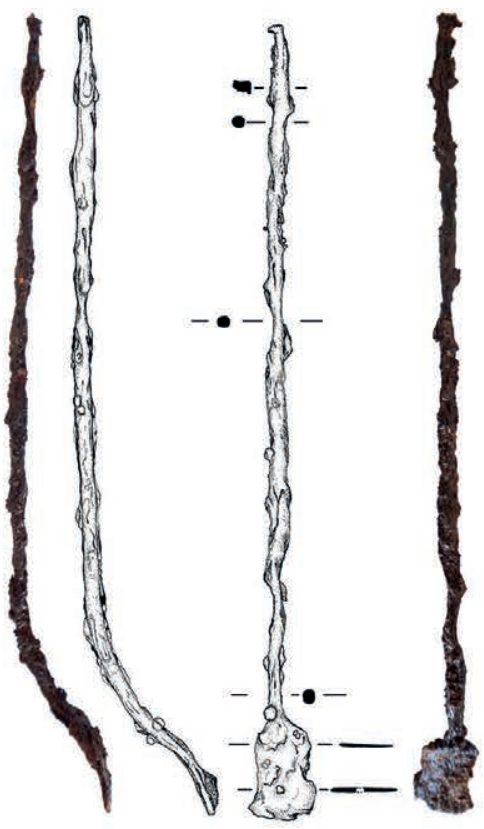

d

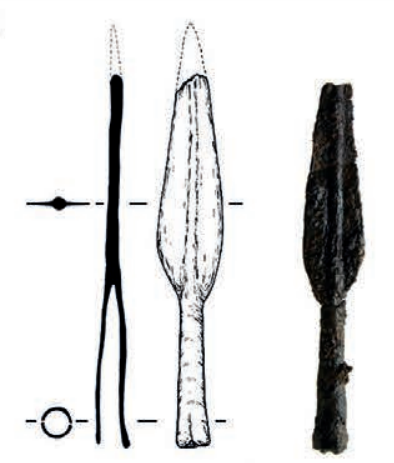

Figura 5. Armamento ofensivo. Armas enastadas: a. pilum LB 23390; b. pilum LB 130379 e imagen del hallazgo; c. pilum LB 145439 e imagen del hallazgo junto a un ánfora Dr. 1; d. punta de lanza LB 137062; e. regatón LB 130605. Fotografías: Héctor Uroz. Dibujos: Nora Hernández. 
Este ejemplar de Libisosa, como el que veremos a continuación, aparece en un contexto estratigráfico con un terminus ante quem del 125 a. C., aunque su producción pudo ser algo - e incluso bastante - anterior, lo que también permite una parte del material de importación asociado, que remonta su actividad a inicios del s. II a. C. A nuestro juicio, sus rasgos tipológicos y formales, ajenos al puñal de filos curvos con espiga y hoja pistiliforme muy acusada, y más cercanos al puñal celtibérico aunque no al modelo tardío con empuñadura de aristas marcadas, lo ubican entre las producciones hispanas, no muy tardías, que encaja bien con un contexto de en torno a mediados del s. II a. C. Aunque nada impide que hubiera sido ya empuñado por un legionario o auxiliar romano.

Este puñal se encontró asociado a la espada anterior, y al conjunto ya citado.

\section{Puñal. N. Inv. LB 152382. Sector 18. Dpto. 176-Estancia 5a. Campaña 2019. Fig. 3d.}

Puñal incompleto de hierro con restos de la vaina de armadura de hierro con cañas de sección en "U". Se conserva la hoja completa y el arranque de la lengüeta plana que servía de núcleo de la empuñadura, doblada intencionalmente casi en $90^{\circ}$. Igualmente se conserva la estructura en chapa metálica de la guarda, de tipo de hombros inclinados o abatidos (Modelo B de Kavanagh, 2008;40-41). La hoja es triangular, con nervio en arista (Hoja Triangular y Sección B de Kavanagh, 2008: 52-55). De la vaina solo restan dos elementos de armadura o "caña" de sección en "U" que dejan un espacio interno de $0,65 \mathrm{~cm}$, para abrazar la estructura de materia orgánica, que pudo ser de madera como en el gladius de Osuna del s. I a. C. (Rouillard, 1997), o de cuero. Estas dos piezas miden 13,8 y 14,1 cm, y abarcan la mitad interior de la hoja. En su parte inferior, donde convergen hacia la punta o extremo distal de la hoja, tienen sendas perforaciones para pasadores o remaches que las unirían entre sí y con una contera arriñonada o esférica, no conservada. En la parte superior de la pieza conservada presentan otros dos orificios, probablemente para fijar una de las abrazaderas horizontales que garantizaban la solidez estructural de la vaina. No se conservan los elementos de unión (normalmente plaquitas de hierro o de aleación de bronce) que armarían la estructura y darían rigidez.

Dimensiones: Lg. Mx. (c): 22,1 cm; Lg. Mx. (e): no hay datos suficientes; Lg. Mx. Hj.: 20,9 cm; An. Mx. Hj.: 4,7 cm.

La estructura de la parte de la empuñadura conservada, la forma, sección y dimensiones de la hoja, y los restos de la vaina no dejan lugar a dudas. Se trata de un puñal de tipo bidiscoidal hispano, muy similar al N. Inv. 152201, aunque un poco más largo (20,9 frente a 19,1 cm) y bastante más estrecho en los hombros (4,7 frente a $5,5 \mathrm{~cm}$ ), lo que hace que tenga unas proporciones bastante más estilizadas. Por sus características formales, no emparenta con los modelos más próximos a los puñales romanos, y una datación de entre fines del s. III y principios del s. I a. C. es adecuada, y no entra en conflicto con la datación estratigráfica del contexto en el que se recuperó. La pieza se encontró en la estancia 5a, asociada a un completo set cerámico de servicio y consumo del vino (Uroz Rodríguez, 2020, e. p. a), y en relación con la espuela LB 152554 y el cuchillo LB 152446.

Aunque el puñal está más incompleto, pertenece al mismo modelo que el anterior ejemplar, por lo que las consideraciones realizadas a propósito del tipo son de aplicación aquí y no las repetiremos. La forma de hoja y sección tienen paralelos cercanos en los contextos sertoriano de Caminreal, con hoja triangular de 19,7 cm (Vicente et alii, 1997: figs. 35-36) o Cáceres el Viejo (Ulbert, 1984: 225-226, taf. 25). En cambio, en el conjunto más próximo cronológicamente a este nivel de Lezuza, del asedio escipiónico de Numancia, los puñales tienen en general hojas marcadamente pistiliformes, cercanas a los modelos de filos curvos estudiados por De Pablo (Luik, 2002: abb. 291, nos. 202, 204, 205). 
Armamento ofensivo. Armas enastadas

No se han localizado hasta el momento, en este contexto cronológico, armas de asta empuñadas o arrojadizas con el impulso del brazo (lanzas, jabalinas, pila etc.)

ARMAMENTO OFENSIVO. ARMAS PROPUlSADAS POR ARCO, HONDA O MÁQUINA

4. Punta de flecha. N. Inv. LB 140582. Sector 18. Dpto. 176-Estancia 1a. Campaña 2011. Fig. 6a.

Punta de flecha incompleta en lámina de hierro forjado. Punta triangular con dos aletas laterales, una rota pero visible, la otra casi por completo perdida. Sección de la hoja plana, sin nervio ni arista. Enmangue por pedúnculo con arranque rectangular plano y comparativamente ancho en su arranque.

Dimensiones: Lg. Mx. (c): 3,4 cm. Debía ser mayor, pero es imposible estimar la Lg. Mx. (e). Lg. Hj/P: 2,7 cm; An. Mx. Hj.: 1,5 cm; An. Ped.: 0,7 cm.

Procede de los niveles superiores de amortización de la estancia 1a del complejo de culto, aunque su inutilización intencional separa esta pieza del resto de armas del ambiente.

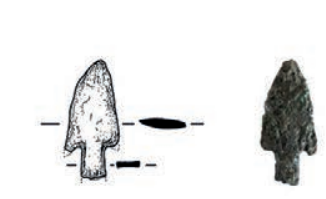

a

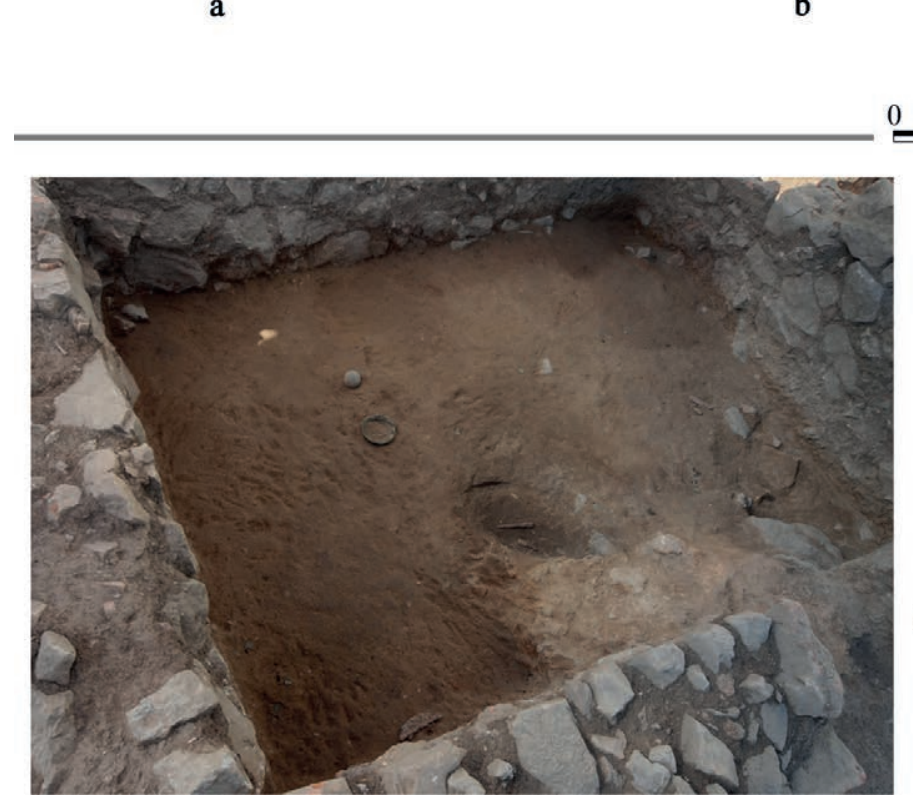

Figura 6. Armamento ofensivo propulsado: a. punta de flecha LB 140582; b. punta de flecha LB 151031; c. bolaño LB 150039: d. imagen del hallazgo del bolaño en el dpto. 191.

Fotografías: Héctor Uroz. Dibujos: Nora Hernández. 
5. Punta de flecha. N. Inv. LB 151031. Sector 18. Dpto. 176-Estancia 3. Campaña 2016. Fig. $6 b$.

Punta de flecha en hierro, casi completa. Hoja lanceolada de tendencia romboidal, con la parte más ancha en el tercio proximal. Marcado nervio de sección circular. Pedúnculo grueso, muy exfoliado, de sección aproximadamente circular.

Dimensiones: Lg. Mx. (c): 4,1 cm; Lg. Mx. Hj.: 2,4 cm; An. Mx. Hj.: 1,35 cm; Gr. Mx. Hj.: $0.35 \mathrm{~cm}$; Diam. Ped.: 0,4 cm.

No es un tipo que, formalmente (sobre todo por su tendencia romboidal en combinación con nervio marcado), se pueda reconocer en las clasificaciones de puntas en aleación de cobre propias de la Edad del Bronce (Kaiser, 2003) o del Bronce Final (Ruiz Zapatero, 1983). Sí se puede considerar tipológicamente romana, del tipo C1 (Quesada y Kavanagh, e. p.), equivalente al Aa de la clasificación de E. Ble (2015: 168, fig. 18). Es un modelo conocido en contextos romanos tardíos como Osuna, ya citado (Quesada, 2008a fig. 8, tipo B). Pero hasta donde sabemos no aparece en contextos más antiguos de fines del s. III a. C. como Baecula (donde las puntas férreas son de cubo, Quesada et alii, 2015: 36 ss.) o el área de la desembocadura del Ebro (Noguera et alii, 2013: 48); tampoco en el gran conjunto de segunda mitad del s. II a. C. de Numancia (Luik, 2002).

Tal y como se ha mencionado en la descripción de la espada LB 152140, pertenece a la estancia con mayor número de armas del complejo.

\section{ARMAMENTO DEFENSIVO ACTIVO}

6. Umbo de escudo. N. Inv. 150993. Sector 18. Dpto. 176-Estancia 3. Campaña 2016. Fig. $7 \mathrm{c}-\mathrm{d}$ y $8 \mathrm{~b}$.

Parte de un umbo de escudo bivalvo en chapa de hierro forjado. Se conserva una valva completa, mientras que la otra, complementaria, no se ha localizado. Uno de los apéndices laterales no se conserva, pero debía ser simétrico al otro. Conserva un orificio de fijación rectangular de 0,7 por $0,2 \mathrm{~cm}$ en un extremo plano; probablemente debió tener otro no visible. En el interior se conservan, adheridos, restos orgánicos no analizados todavía, probablemente madera (Fig. 7d).

Dimensiones: Lg. Mx.: 22,7 cm; An. Mx. Hj.: 8,7 cm (centro de la concha); 7,8 cm (base); centro de la concha: $7 \mathrm{~cm}$. No es posible determinar el grosor de la lámina férrea, en torno a $0,1 \mathrm{~cm}$, pero sin duda es sólida y funcional.

Pertenece a la estancia con mayor acumulación de armamento del edificio de culto, y se encontró directamente asociado a una botella y un plato de pie alto de cerámica ibérica (Fig. 8b).

Esta pieza es una mitad, quizá asimétrica, de un gran umbo bivalvo, del tipo recuperado completo en la Calle 1, en un contexto de destrucción sertoriano (N. Inv. 130298, vid. infra). No cabe duda de que se trata de un refuerzo metálico en forma de dos conchas para cubrir un umbo de madera con spina o nervio prolongado en el eje longitudinal que, aunque concebiblemente pueda ser aplicado a los grandes escudos circulares de La Tène, en el contexto galo normal, itálico e hispano corresponde a escudos ovales (thureos, scutum) (Fig. 7a). En este caso, la forma de la pieza indica que las aletas planas se adhieren a la superficie plana del cuerpo del escudo, y la concha se eleva en diagonal para abrazar el umbo de madera. Como es habitual en estas piezas, llama la atención la presencia de solo dos pequeños orificios para remaches que difícilmente asegurarían la pieza en caso de los golpes que estaba destinada por diseño a sufrir, lo que nos ha llevado a proponer en otro lugar que debían estar además encoladas (García Jiménez y Quesada, 2014: 21). 

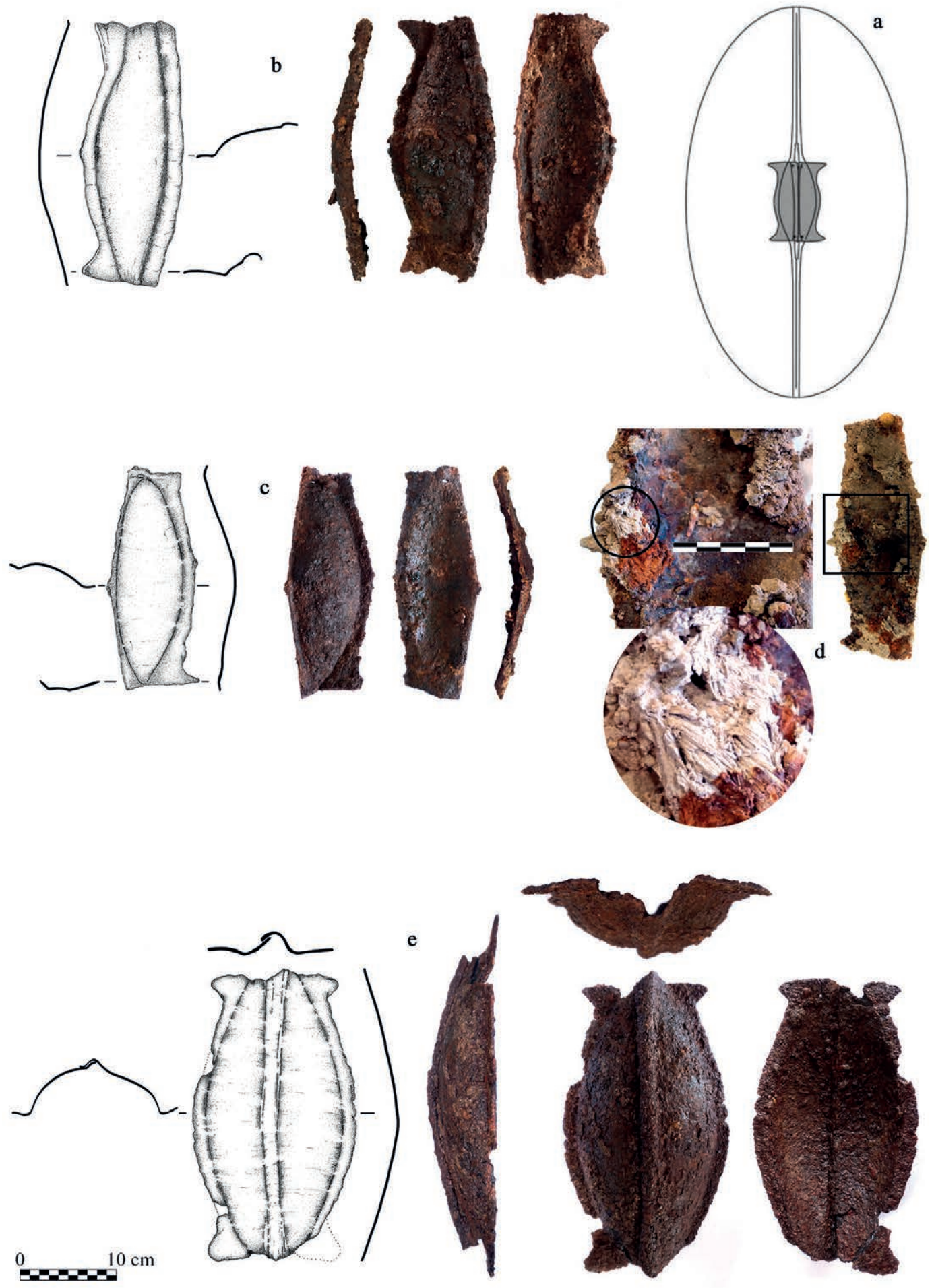

Figura 7. Armamento defensivo activo. Umbos bivalvos: a. esquema de scutum con umbo bivalvo (García Jiménez y Quesada 2014: fig 1b); b. umbo de escudo LB 145429; c. umbo LB 150993; d. restos orgánicos adheridos en el interior de LB 150993; e. umbo de escudo bivalvo completo LB 130298. Fotografías: Héctor Uroz. Dibujos: Nora Hernández. 
a

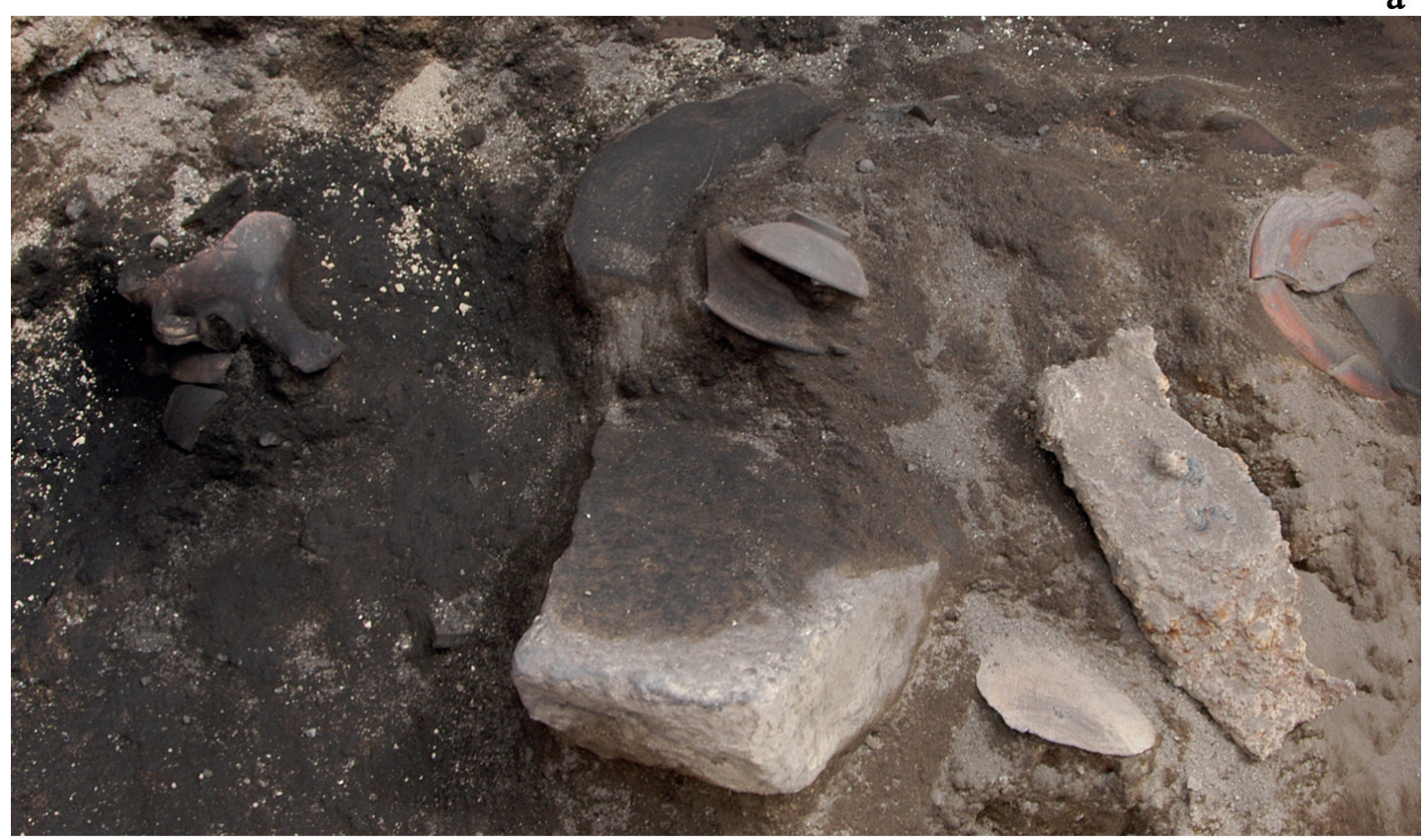

b

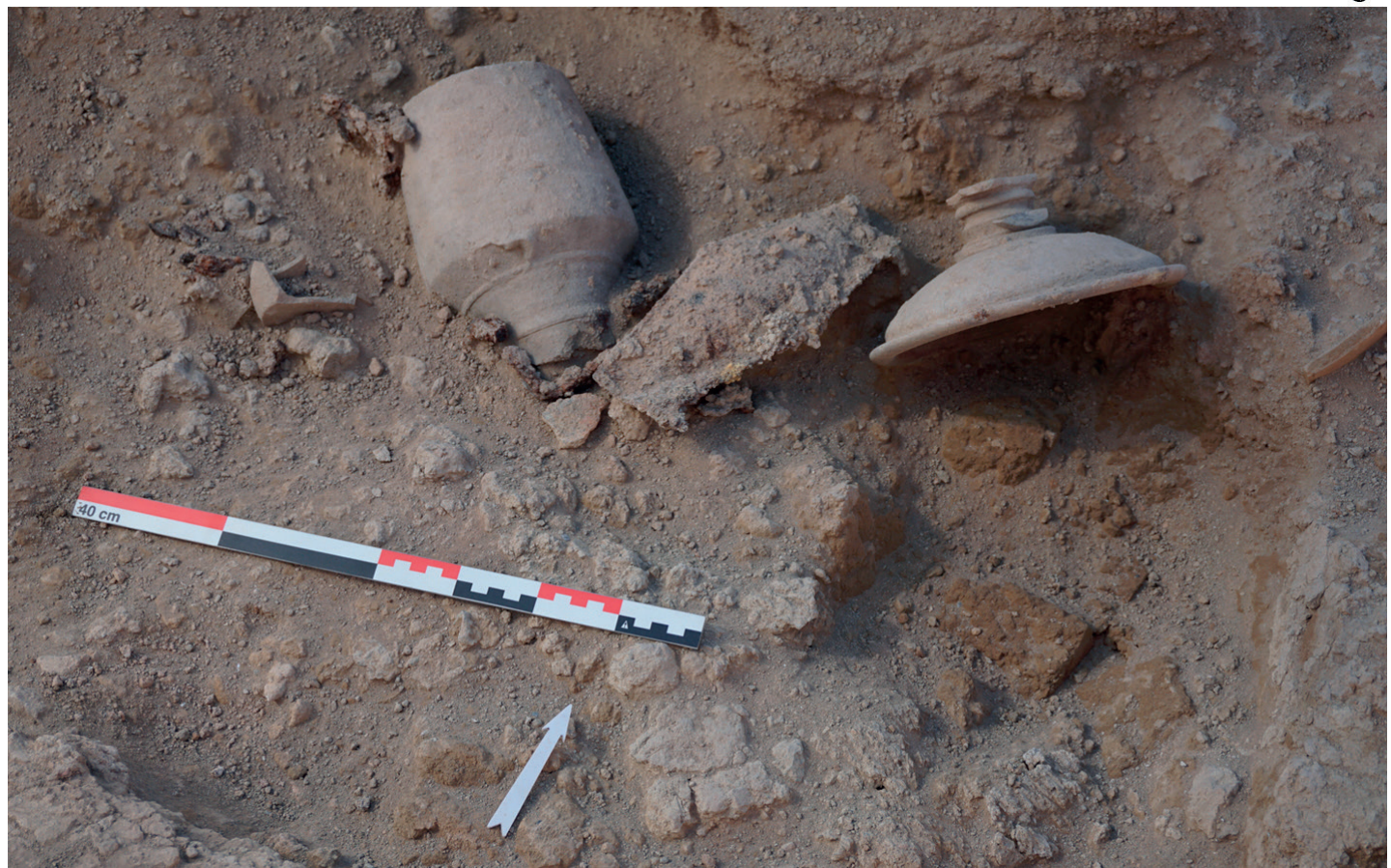

Figura 8. Contexto del hallazgo de los umbos bivalvos del dpto. 176: a. LB 145429; b. LB 150993. Fotografías: Héctor Uroz. 
7. Umbo de escudo. N. Inv. 145429. Sector 18. Dpto. 176-Estancia 1a. Campaña 2013. Fig. $7 \mathrm{~b}$ y $8 \mathrm{a}$.

Parte de un umbo de escudo bivalvo en chapa de hierro forjado. Se conserva una valva completa. Apéndices laterales atrofiados. No se aprecian orificios de fijación al cuerpo del escudo. Se aplica pues lo indicado para la pieza anterior.

Dimensiones: Lg. Mx.: 27 cm; An. Mx. Hj.: 10,8 cm (centro de la concha). No es posible determinar el grosor de la lámina férrea, en torno a $0,1 \mathrm{~cm}$, pero sin duda es sólida y funcional.

Se trata de un objeto en apariencia similar al que se acaba de analizar, pero con una notable diferencia. Como en las piezas de Romazal, Pozo Moro y otras (García Jiménez y Quesada, 2014), presenta un reborde plegado que sirve tanto como cubre-spina como para superponerse sobre la otra mitad del umbo, la otra valva, que no tendría este reborde. No se corresponde, por tanto, con aquella, de diferente tamaño e incompatible. De hecho, aunque cabría pensar en una reparación empleando dos mitades de umbos disímiles, la diferencia de longitud (esta pieza es $5 \mathrm{~cm}$ más larga) y de ancho (más de $2 \mathrm{~cm}$ de diferencia) así como de forma, haría antiestético y, sobre todo, poco funcional tal acoplamiento sobre una base de madera en la spina del escudo, aunque podría ser factible.

El contexto directo de aparición de esta pieza es el nivel inferior de incendio sobre el pavimento de la estancia 1a (Fig. 8a), compartido con los vasos plásticos rituales, askoi y gutti (Uroz Rodríguez, 2018).

\section{ELEMENTOS DE MONTA Y CONTROL DEL CABALLO}

8. Elemento de cabezada. N. Inv. LB 130789. Sector 18. Dpto. 176-Estancia 1a. Campaña 2010. Fig. 11b.

Pieza de hierro en forma de barra forjada con poca precisión, de sección cuadrangular. En un plano presenta en los extremos dos anillos rígidos de forja. Uno de ellos, completo, sostiene todavía una gran anilla móvil de mucha menor sección. El otro extremo, partido, debía ser simétrico y sostener otra anilla móvil. En el plano perpendicular a noventa grados, en el centro, presenta un saliente rectangular, dañado, que deja un hueco u ojal grande por el que podría pasar otra gran anilla móvil o una correa ancha y plana de cuero. De este modo, si la pieza está tensada por sus extremos, en su centro, a $90^{\circ}$, se proyecta otra anilla para una fijación independiente.

Dimensiones: Lg. Mx.: 26,8 cm (sin anillas). Diámetro de la anilla móvil: 3,8 cm; An. Mx.: $1,3 \mathrm{~cm}$.

Este objeto corresponde a un tipo de arreo de caballo, sin duda, pero de discutida identificación funcional. Es bastante habitual tanto en las necrópolis celtibéricas como en el ámbito ibérico. Se ha considerado a veces como elemento de cama de un bocado de filete, aunque morfológicamente no parece posible (ver ejemplo propuesto por J. Cabré en 1930 en Quesada, 2005: 30 y fig. 25).

En Carratiermes (Soria) se clasifica como Tipo 6, y siguiendo en parte a Schüle (1969), se identifica - a nuestro juicio correctamente-, como parte de una cabezada rígida, en concreto carrillera o mejillera, y a menudo aparece en un extremo una pieza curva que actuaría de nuquera (Argente et alii, 2001: 75 ss. y fig. p. 72) no presente en esta pieza de Lezuza. Corresponde a nuestro Grupo B de elementos de arreo en hierro de la Edad del Hierro (Quesada, 2005: fig. 21). Sin embargo, es curioso que estas piezas muy a menudo aparecen aisladas, no por pares como sería lo lógico, y sin su correspondiente bocado. Las anillas móviles de esta severa cabezada enlazarían con las correas de cuero del resto de la estructura (serretón, 
frontalera) y el orificio del saliente cuadrangular central no serviría para un filete, sino para un ahogadero o una barbada (Quesada, 2005: fig. 23).

La estancia 1a es la que mayor acumulación de vasos rituales y vajilla de importación contiene, con diferencia, de todo el edificio (Uroz Rodríguez, e. p. a).

\section{Espuela. N. Inv. LB 151092. Sector 18. Dpto. 176-Estancia 3. Campaña 2016. Fig. 12a.}

Cuerpo de espuela rígida en bronce con acicate corto en hierro. Cuerpo de la espuela solo muy ligeramente asimétrico para facilitar el trabajo del talón. Cuerpo con sección en forma de "D" aplanada y facetada, con la cara interna plana y la exterior en triple faceta. El muy corto y cónico acicate de hierro se remacha al cuerpo mediante una moldura con una escocia entre dos toros. En el interior se proyecta el remache de hierro, visible por óxido. Para la correa de sujeción a tobillo se practicaron en los extremos sendos orificios circulares por los que debieron pasar anillas móviles de hierro, de las que quedan restos de óxido. En las fenestras propiamente dichas se aprecian por el interior cabezas de pequeños remaches de hierro. Presenta varios elementos decorativos: en los extremos laterales, junto a los orificios para la correa de sujeción, dos molduras cuadradas salientes decoradas con sendas series de líneas incisas verticales; en el centro (ligeramente asimétrico como se ha dicho) molduras rectangulares salientes que enmarcan la moldura de toros y escocia en bronce que sirve de apoyo al acicate de hierro propiamente dicho.

Dimensiones: Lg. Mx. (de extremo a extremo): 7,6 cm; An. Mx.: 0,8 cm; Lg. Acicate: 1,2 $\mathrm{cm}$ incl. moldura de base.

La pieza que nos ocupa pertenece al Grupo Quesada 4.A (Quesada, 2005: 33-42, específicamente p. 41). El Grupo 4 se define por un cuerpo que no es ni una placa ancha (Grupo 2) ni una tira plana estrecha (Grupo 3) de metal, sino una barra gruesa y estrecha de sección más o menos trapezoidal o semicircular, cuya anchura máxima no llega al centímetro; el acicate, además, suele ser muy corto. Incluye varios subtipos: con orificios horizontales y cuerpo rematado de diversos modos (4A.1, 4A.2, 4A.3); con orificio diagonal (4B), con extremos serpentiformes (4C), etc. Aunque la cronología general es larga, esta pieza en principio muestra rasgos evolucionados en su decoración y moldura del aguijón.

Como ha quedado subrayado con anterioridad, la estancia 3 es la que mayor acumulación de armamento y elementos de monta presenta de todo el complejo.

10. Espuela. N. Inv. LB 145374. Sector 18. Dpto. 176-Estancia 1a. Campaña 2013. Fig. 12b.

Espuela rígida incompleta, se conserva aproximadamente la mitad del cuerpo y el acicate se ha perdido. Cuerpo de placa estrecha pero gruesa de bronce, plana al interior y facetada al exterior, con una sección en forma de " $\mathrm{D}$ " aplanada. Soporte para el acicate de hierro en forma de una moldura de bronce con dos toros. Extremos del cuerpo ensanchados para admitir cómodamente dos orificios circulares horizontales para una anilla móvil a la que se fijarían las correas de sujeción. El acicate de hierro se ha perdido. Decorada con una moldura en cada extremo del cuerpo, antes del ensanchamiento para el orificio, cubierta con incisiones verticales. Sistema similar en el centro del cuerpo, a ambos lados de la moldura para la recepción del acicate.

Dimensiones: Lg. Mx. (estimada): 7,8 cm; Lg. (c): 6,3 cm; An. Mx.: 0,5 cm.

La forma, dimensiones y decoración de esta espuela es muy similar a la que presenta la $\mathrm{N}$. Inv. 151092 (supra), con la que incluso podría haber formado pareja (aunque se encontraron en habitaciones distintas), a pesar de ser esta pieza más estrecha y tener los extremos más engrosados. Pertenece al Grupo 4, Tipo 4a (Quesada, 2005: 41), bastante tardío en el conjunto 
de la península. Para el resto de consideraciones relevantes sobre estas espuelas remitimos a lo dicho en el anterior análisis.

\section{Espuela. N. Inv. LB 152142. Sector 18. Dpto. 176-Estancia 3. Campaña 2017. Fig. 12e.}

Espuela de placa de hierro moldurada en media caña en la parte superior e inferior, cubierta al exterior (entre las dos molduras horizontales) con una lámina de aleación de cobre (dorada en inicio, por tanto). La lámina está adherida al cuerpo de hierro mediante dos series de tres remaches de hierro, que atraviesan el cuerpo. Espuela marcadamente asimétrica para mejorar el control de talón. Ventanas o fenestras rectangulares en los extremos de la placa para pasar las correas de sujeción. Acicate largo de hierro forjado, remachado a la placa a través de un agujero en su parte central.

Dimensiones: Lg. Mx. (de extremo a extremo de la placa): 7,3 cm; An. Mx. placa: 1,6 cm; Lg. Pt./Acic.: 3,9 cm; Ge. placa: 0,2 cm.

Se trata de una espuela que puede clasificarse en el Grupo 2 de espuelas peninsulares, el más frecuente, $\mathrm{y}$ en concreto en el tipo $2 \mathrm{~B}$, con molduras horizontales en la parte superior $\mathrm{e}$ inferior de la placa y fenestras rectangulares. Con 1,6 cm de anchura, es algo más estrecho que la mayoría de las piezas de este grupo, aunque el Tipo 2B es el más estrecho de todos (Quesada, 2005: 39 y fig. 34). El cuerpo férreo, sin ser habitual, no es en modo alguno excepcional. Menos frecuente es la cubierta de lámina de aleación de cobre. Es un modelo de amplia perduración entre el s. IV a. C. y el II e incluso I a. C.

\section{Espuela. N. Inv. LB 149940. Sector 18. Dpto. 176-Estancia 3. Campaña 2014. Fig. 12f.}

Espuela de cuerpo rígido en aleación de cobre, con sección en "D" redondeada. Falta por completo el aguijón, aunque hay restos de óxido de hierro. Cuerpo ligeramente asimétrico para facilitar el trabajo del talón del pie. En los extremos del cuerpo, aplanados, dos orificios verticales (no horizontales) y restos de anillas móviles de hierro para engarzar la correa de sujeción. Los dos extremos están separados del resto del cuerpo por una pequeña moldura decorativa.

Dimensiones: Lg. Mx.: 8,9 cm; An. Mx. Hj.: 0,8 cm.

La espuela se clasifica centro del Grupo 5, tipo 5A, similar al Grupo 4, pero con los orificios para anillas en posición vertical en lugar de horizontal (Quesada, 2005: 41). Es un tipo avanzado.

Se trata de una de las tres espuelas recuperadas en la estancia 3, junto a LB 151092 y 152142.

\section{Espuela. N. Inv. LB 152554. Sector 18. Dpto. 176-Estancia 5a. Campaña 2019. Fig. 12c.}

Espuela rígida en aleación de cobre. Falta el acicate de hierro. Cuerpo deformado, estrecho y sección gruesa en "D" y moldura central horizontal en el centro. Ligera asimetría para facilitar trabajo del talón. En el centro, moldura decorativa cuadrada para recibir el acicate. En los extremos, engrosamiento de forma cuadrangular para recibir orificio circular horizontal para anillas móviles y correa de sujeción.

Forma parte del importante conjunto de espuelas localizado en el departamento 176, formado al menos por cinco piezas. De hecho, cinco de las seis espuelas de la fase del s. II a. C. proceden de esta estancia, lo que sin duda tiene significado y sobrepasa lo habitual en lugares como, por ejemplo, la Bastida de Mogente, donde las espuelas y arreos de caballo se distribuyen por las diferentes viviendas — de algún rango - con cierta regularidad (Quesada, 2011: 213, fig. 19).

Dimensiones: Lg. Mx.: 8,8 cm; An. Mx. Hj.: 0,8 cm.

La espuela forma parte del tipo 4A (Quesada, 2005: 41), de época avanzada. 


\section{Espuela. N. Inv. LB 152580. Sector 18. Dpto. 195. Campaña 2019. Fig. 12d.}

Espuela rígida sencilla. Cuerpo de aleación de cobre, con arranque del aguijón, casi perdido, en hierro. Marcadamente asimétrico. Sección en "D" con la parte plana al interior. Orificios rectangulares en los extremos para correa o, más probablemente, anilla móvil.

Dimensiones: Lg. Mx.: 7,5 cm; An. Mx. Hj.: 0,9 cm.

Tipo 4A de Quesada (2005: 41), de fecha avanzada.

Estamos ante el único objeto del conjunto del s. II a. C. recuperado fuera del complejo de culto 176, si bien este pequeño departamento 195, que colinda con aquel por el noreste, y se encuentra igualmente por debajo del nivel de la calle sertoriana (calle 3), parece compartir además y de alguna manera funciones rituales, en virtud del carácter del registro material recuperado hasta ahora en su interior, aun teniendo en cuenta que se encuentra todavía en proceso de excavación.

\section{Otros: Cuchillos}

15. Hoja de Cuchillo. N. Inv. LB 152446. Sector 18. Dpto. 176-Estancia 5a. Campaña 2019. Fig. 13 b.

Gran fragmento de cuchillo de ancha y sólida hoja de sección triangular, sin filo dorsal y buen peso. Se conserva la hoja completa y el arranque de la lámina de la empuñadura. La hoja es ancha y gruesa (casi medio cm), con una inflexión leve angular en el dorso a mitad de hoja, pero sin la característica curvatura en el filo de los cuchillos afalcatados. A ambos lados, cerca del dorso o lomo, hay un vaceo profundo. Se aprecia marca de óxido diferencial hacia el final de la hoja, indicando el lugar donde empezaban las cachas orgánicas de la empuñadura, de las que podrían quedar algunos restos no analizados todavía. También en la zona de la empuñadura se aprecia un resto muy deteriorado de un posible remache de fijación.

Dimensiones: Lg. Mx. (c): 10,5 cm; Lg. Mx. (e): indeterminable; Lg. Mx. Hj.: 8,2 cm; An. Mx. Hj.: 2,4 cm; Gr. Mx. Hj.: 0,4 cm; An. Bas.: 2,4 cm.

Hallado en el mismo habitáculo que la espuela LB 152142.

16. Hoja de Cuchillo. N. Inv. LB 152198. Sector 18. Dpto. 176-Estancia 3. Campaña 2017. Fig. 13a.

Gran cuchillo de hoja gruesa, ancha y acodada, con inflexión angular en el dorso. Sección triangular sin vaceos. Sin filo dorsal. Sin inflexión en el filo. Empuñadura de espiga de sección cuadrangular, gruesa. Falta el extremo distal de la hoja.

Dimensiones: Lg. Mx. (e): 23,8 cm; Lg. Mx. Hj. (e): 15 cm; LIE: 8,8 cm; An. Mx. Hj.: 2,9 $\mathrm{cm}$.

Se trata de un cuchillo no afalcatado, sino de dorso acodado y hoja de filos sensiblemente paralelos, de una tipología tardía. Cuchillos similares se han encontrado en contextos militares romanos del s. I a. C., como Cáceres el Viejo (Ulbert, 1984: taf. 27, n. 238, 240) o Caminreal (Iriarte et alii, 1997: fig. 38).

Completa el catálogo de armamento y arreos de caballo recuperado en la estancia 3 del complejo de culto, compuesto por la espada LB 152140, uno de los puñales (LB 152201), una de las partes de umbo de escudo bivalvo (LB 150993), una punta de flecha (LB 151031) y tres de las espuelas (LB 151092, 149940 y 152142). 


\section{CATÁLOGO RAZONADO. ÉPOCA "SERTORIANA"}

\section{ARMAMENTO OFENSIVO: ARMAS EMPUÑADAS}

\section{Espada. N. Inv. LB 130597. Sector 18. Dpto. 172. Campaña 2010. Fig. 3b y 4b.}

Espada de hoja recta. Espiga de sección rectangular aplanada. Hombros caídos y muy anchos, con rápida disminución en el tercio débil generando un claro recorrido pistiliforme de la hoja. Sección de la hoja romboidal con arista muy poco marcada, tendente a lenticular.

Dimensiones: Lg. Mx. (c): 72 cm; Lg. Mx. (e): 79; Lg. Mx. Hj.: 66,5 cm; An. Mx. Hj. (en los hombros): 5,2 cm; An. Mn. Hj. (tercio medio): 4,6 cm.

La segunda - y última por ahora - espada identificada en Lezuza, aunque adscrita al contexto sertoriano ulterior, pertenece claramente a la familia de su homóloga más antigua, Quesada VIIC/García Jiménez D.2. De hecho, es un arma mucho más característica por su hoja pistiliforme, pero sobre todo por sus hombros abultados que García Jiménez ha definido gráficamente de aspecto "cabezón". Los hombros son acusadamente caídos y muy anchos, disminuyendo enseguida esa dimensión. La hoja es acusadamente pistiliforme y robusta, con punta poderosa. A nuestro juicio, que coincide con el de García Jiménez (com. pers.) se trata de un tipo D.2 (García Jiménez, 2012: 123 ss.). Su longitud de hoja de 66,5 cm es característica (el tipo tiene un recorrido de 63 a $68 \mathrm{~cm}$ ); y el ancho máximo de la hoja, de 5,2, igualmente en el recorrido de 5,3 a 6,2 (García Jiménez, 2012: 123).

Dicho de otro modo, es un ejemplo claro de gladius hispaniensis que se aleja ya algo de los prototipos hispanos (el modelo La Tène I hispanizado, cf. Quesada, 1997b) y entra en los modelos de hoja ya más romanos, como los sertorianos de La Azucarera (Iriarte et alii, 1996; 1997) o el gladius de Osuna de época cesariana con sección claramente a cuatro mesas (Sievers, 1997: 274; Sievers en Rouillard, 1997: 67). El gráfico de García Jiménez (2012: 161, fig. 62) que amplía y detalla con muchos hallazgos nuevos el primitivo de Quesada (1997a: 266, fig. 156 y 1997b: 265, 265) encuadra perfectamente esta espada en un modelo que a cualquier legionario (o auxiliar) del s. I le resultaría no ya familiar, sino propio. El contexto del depósito de la Azucarera, de fines del s. II o más probablemente de época sertoriana, es un buen paralelo para las dos espadas de Libisosa, y en particular para este ejemplar de aspecto algo más avanzado.

Apareció tumbada en el suelo del departamento 172, sobre el pavimento y casi perpendicular al muro perimetral oriental. Este ambiente, como se ha mencionado con anterioridad, se ha puesto en relación con el edificio colindante oligárquico (dpto. 127). Se trata de una gran bodega de $77 \mathrm{~m}^{2}$, destinada al control de los excedentes, para su comercio o redistribución interna, donde se recuperaron en torno a 80 ánforas-tinaja ibéricas y una importante acumulación de vajilla de bronce (Uroz Rodríguez, 2015 y e. p. a: 80-85).

\section{ARMAMENTO OFENSIVO: ARMAS ENASTADAS}

\section{Pilum. N. Inv. LB 23390. Sector 3. Dpto. 59. Campaña 1999. Fig. 5a.}

Parte férrea de un pilum de gran tamaño, con una longitud de en torno a los $70 \mathrm{~cm}$ en origen. Enmangue de cubo hueco circular, largo vástago de hierro de sección sub-circular que refleja los golpes de forja. Falta el extremo distal, incluyendo la punta completa. El cubo tiene un diámetro reducido de $c .1,5 \mathrm{~cm}$, que se mantiene a lo largo de casi toda su longitud, para estrecharse abruptamente al comienzo del vástago de hierro que en origen apenas llegaría a los $0,8 \mathrm{~cm}$ de diámetro y superaría los $50 \mathrm{~cm}$ de longitud hasta el arranque de la punta, perdida 
como se ha dicho. La chapa metálica del cubo tiene un grosor algo mayor de $0,1 \mathrm{~cm}$. En su base el cubo presenta una virola o abrazadera plana de 1,1 cm de ancho. Es de aleación de cobre, y presenta una doble moldura. Su función es probablemente asegurar la unión al asta de madera y reforzar su solidez, punto en el que Polibio hace gran énfasis $(6,23,11)$.

Dimensiones: Lg. Mx.: 64 cm; Lg. Mx. (e): > 70 cm; Lg. asta: $>50$ cm; Lg. Cb.: 13,3 cm; Diam. Cb.: 1,5 cm; Diam. asta: 0,5 cm; Gr. Cb.: $>0,1 \mathrm{~cm}$.

Puede incluirse en el tipo que suele considerarse "romano", aunque ya desde el s. V a. C. hay pila ibéricos de forma similar o casi idéntica (Quesada, 2007: fig. 382). Paralelos cercanos en el tiempo y en el espacio son, por ejemplo, los largos y pesados ejemplares de $c .75$ a. C. de la Almoina de Valencia (e. g. Ribera, 2014: 73, fig. 12), o los casi contemporáneos de Cáceres el Viejo (Ulbert, 1984: taf. 24.192), aunque los hay más antiguos como en Numancia (Luik, 2002: abb. 183).

Se trata de la única pieza del conjunto procedente del sector 3. Concretamente se recuperó en el departamento 59, espacio en el que se ha identificado actividad textil (hilado y tejido), y en el que se recuperó un importante registro material, incluyendo los vasos singulares del "Lebes de los ciervos" y el "Oinochoe de la dama", un lote de producciones tardías de barniz negro de Neapolis y Cales, y la rueda de carro mejor conservada de toda esta fase (Uroz Sáez et alii, 2003: 321-323; Uroz Rodríguez, 2012: 244-245; 310-312, 324-325; e. p. a), junto a la recuperada en la estancia 3 del dpto. 127 (Uroz Rodríguez, 2012: 262-263; Uroz Sáez y Uroz Rodríguez, 2016: 164-165, fig. 3).

\section{Pilum. N. Inv. LB 130379. Sector 18. Dpto. 190. Campaña 2009. Fig. 5 b.}

Parte férrea completa de un pilum de gran tamaño y muy bien conservado, con una longitud de $60,3 \mathrm{~cm}$. Enmangue mediante cubo, cuya longitud interior alcanza como mínimo 11,5 $\mathrm{cm}$, lo que asegura un enmangue sólido. Conserva además restos de un pasador de fijación, diametral, en hierro. Presenta un anillo en la base del cubo, similar al de LB 23390. A 13,5 $\mathrm{cm}$ de la base del cubo se dibujan dos delgadas molduras toroidales separadas entre sí por 2 $\mathrm{cm}$, decorativas. La sección del vástago macizo es de sección circular, de en torno a $0,9 \mathrm{~cm}$ en su centro, sin adelgazar apenas hacia la punta. La punta es piramidal, de sección cuadrada, pero con la base lobulada en cuatro aletas atrofiadas, muy poco frecuente. Esta se encuentra fuertemente doblada por impacto, mientras que el conjunto del asta está solo muy levemente curvado, lo que una vez más viene a demostrar la falsedad del mito del "pilum diseñado para doblarse" (ver Polibio 6,23 contra Plutarco Mario 25 y discusión al respecto en Connolly, 2001-2002: 7; Quesada, 2008b: 226-228; McDonnell-Stalff, 2010; Grab, 2011; Bishop, 2017: 15-16 etc.).

Dimensiones: Lg. Mx. (e): 60,3 cm; Lg. Mx. P.: 6,3 cm; Lg. Cb.: 12 cm; Lg. asta: 54 cm; Gr. Cb.: 0,12 cm; Diam. Cb.: 2 cm; Diam. asta: 0,9 cm; Peso: 280 gr.

Los paralelos de este tipo de pilum son los mismos del caso anterior. Sin embargo, la punta, peculiar, no es conocida en otros yacimientos del periodo en Iberia como Numancia, Cáceres el Viejo, Valencia o Caminreal, donde la forma habitual es piramidal cuadrada muy alargada. En cambio, en el depósito de armas romanas de Smihel, en Eslovenia, se conoce algún pilum largo con enmangue de lengüeta plana y puntas idénticas (Horvat, 1997: fig. 5.4; 2002: pl. 6). El depósito de Smihel viene datándose en la primera mitad del s. II a. C.

El contexto en el que apareció la pieza, el departamento 190, anexo por el este a la bodega numerada como 172, resulta extremadamente peculiar, no habiéndose registrado el recurrente "efecto sepultura" provocado por la caída de las paredes de adobe, y contando únicamente como registro material reconocible con este pilum y un tedero de hierro en perfecto estado de conservación (Uroz Rodríguez, e. p. a y e. p. b). 


\section{Pilum. N. Inv. LB 145439. Sector 18. Dpto. 187. Campaña 2013. Fig. 5c.}

Parte metálica casi completa de un pilum largo con enmangue de lengüeta plana. Se conserva con seguridad un orificio para remache grueso de $0,6 \mathrm{~cm}$ de diámetro. Asta de sección subcircular. Punta piramidal muy corroída y deformada, de sección aproximadamente cuadrangular. Extremo de la punta doblado $90^{\circ}$ por impacto. Asta doblada de manera acusada en extremo proximal, posiblemente por el mismo impacto.

Dimensiones: Lg. Mx.: 50,5 cm; Lg. Pta.: 5,5 cm; Lg. asta: 39 cm; Lg. lengüeta: 6 cm; An. lengüeta: $3,9 \mathrm{~cm}$.

Se trata de un tipo habitual de pilum pesado de lengüeta de fines del s. II a mediados del s I a. C. La lengüeta (pese a la apariencia por rotura) no adopta la forma de "reloj de arena" característica por ejemplo en algunos ejemplares de Smihel del s. II a. C. o en Telamon (Bishop, 2017: 13) pero aun así es bastante corta y de tendencia cuadrangular, a diferencia de las lengüetas muy alargadas de los ejemplares de Renieblas, Valencia o la Caridad, lo que da a este ejemplar sertoriano de Lezuza una apariencia más antigua, próxima a la de ejemplares numantinos del último tercio del s. II o de principios del I si, como parece, proceden de Renieblas III y IV que pueden datarse en el s. II y en época sertoriana, como Lezuza (Luik, 2002: abb. 181, 133a, 135). Pero en cambio, tampoco tiene los bordes plegados para mejorar la fijación como en algunos ejemplares republicanos de fines del s. III y s. II a. C. (Bishop, 2017: 3 de Castellruf; 14 de Smihel).

El departamento 187 en el que se recuperó, por tamaño y registro material (cerámica fina y de cocina ibérica, herramientas y ruedas en reparación, ánfora y vajilla de bronce romana), remite a los reducidos espacios plurifuncionales que conforman el sector 3 .

21. Punta de lanza. N. Inv. LB 137062. Sector 18. Dpto. 127-Estancia 5. Campaña 2007. Fig. $5 \mathrm{~d}$.

Moharra de lanza en hierro, casi completa y bien conservada. Faltan unos 2,5 cm de la punta. Hoja de forma lanceolada "de sauce" con anchura máxima en el cuarto proximal, nervio no excesivamente grueso de sección redondeada (Quesada tipo 1, 1997a: 357, fig. 208) y cubo proporcionalmente largo (Índice 2: 1,93). En la base del cubo aparecen dos pequeñas perforaciones diametralmente opuestas para un pasador de fijación del asta. El cubo presenta huella de sutura longitudinal de forja.

Dimensiones: Lg. Mx. (c): 22,8 cm; Lg. Mx. (e): 25,8 cm; Lg. Hj.: 17 cm; Lg. Cb.: 8,8 cm; An. Mx. Hj.: 4,1 cm; Gr. Cb.: 0,13 cm; Diam. Cb.: 2 cm; Índice 1 (Lg. Mx. Hj. / An. Mx. Hj.) $=4,15$; Índice 2 (Lg. Hj. / Lg. Cb.) = 1,93.

Se trata de una punta comparativamente grande y pesada para lo que es habitual en contextos del s. I a. C., cuando predominan ya lanzas más cortas y estrechas sin nervio, con secciones a cuatro mesas romboidales o lenticulares, y con cubos de menor diámetro. Se clasifica bien dentro de la Variante VC, tipo 5a de Quesada (1997a). La variante VC es, junto con la VB, la más frecuente y extendida en el armamento peninsular de la Edad del Hierro (Quesada, 1997a: 369). El código "V" indica que la anchura máxima de la hoja se alcanza en el primer $20 \%$ de su longitud; el "C" que se trata de una hoja comparativamente ancha y poco estilizada, con independencia de su tamaño total (Índice $1<5$ ). De hecho, con sus $25,8 \mathrm{~cm}$ de longitud, nuestra lanza está ligeramente por encima de la media de la variante, que es de 22,3 cm. En este tipo de lanzas, la sección con nervio es más característica del ámbito ibérico (en el SE está muy extendida); mientras que en las mesetas predominan las secciones sin nervio. La cronología de la variante abarca desde el s., IV a. II a. C., aunque puede llegar a las primeras décadas del s. I a. C. 
Agrupada la variante VC con la VB y IIIC en el tipo 5a (Quesada, 1997a: 400-401), este se define por lanzas medianas y cortas $(<35 \mathrm{~cm})$ y nervio marcado. Anchura máxima en el 20 $\%$ proximal. Tipo de amplia cronología y difusión global.

Apareció, fragmentada y probablemente amortizada, dentro de una de las ánforas-tinaja ibéricas apiladas en cantareras en la estancia 5 del edificio oligárquico -dpto. 127 (Uroz Rodríguez, 2012: 286).

\section{Regatón. N. Inv. LB130605. Sector 18. Dpto. 172. Campaña 2010. Fig. 5e.}

Contera y probable regatón (contera aplicada no a un bastón o a un poste de tienda de campaña). En lámina de hierro forjado. Sin orificios visibles para pasador de fijación. Sin restos de lámina de $\mathrm{Cu}$ en el interior.

Dimensiones: Lg. Mx.: 14,7 cm; Diam. Cb.: 2,2 cm; Gr. Cb.: 0,16 cm.

Se trata de un regatón bastante grueso y grande, pensado para acomodar un asta relativamente gruesa. En el contexto del s. I a. C., con moharras progresivamente más pequeñas y ligeras, aptas para lanzar tanto como para empunar, los regatones grandes se hacen más infrecuentes y ligeros, aunque nunca desaparecen. Sobre las distintas funciones del regatón, ver amplio resumen en Quesada (1997a: 427-431).

Se encontró en la gran bodega-dpto. 172, cerca de la hoja de espada LB 130597, en los niveles de derrumbe del cercano muro perpendicular divisorio al que apareció aquella.

\section{ARMAMENTO OFENSIVO PROPULSADO POR MÁQUINA}

\section{Bolaño. N. Inv. LB 150039. Sector 18. Dpto. 191. Campaña 2014. Fig. 6c-d.}

Bolaño (proyectil de artillería, en este caso neurobalística), de forma esférica ligeramente irregular. Piedra cuarcita gris extremadamente dura, posiblemente por metamorfismo de una cuarzo-arenita. ${ }^{8}$

Dimensiones: Diam. Máx. 7,5 cm; Diam. Min.: 7,2 cm; Peso: 580 gr.

Es un proyectil, del tamaño de una naranja, pequeño y que no se ajusta —en principioa los calibres estándares del periodo helenístico o romano altoimperial, ni está fabricado en las piedras volcánicas o calizas más habituales (Ble, 2015: 241-243). Por ello, cabría pensar alternativamente en alguna otra función no militar, o al menos no como proyectil de artillería. La cuestión queda por ahora en suspenso, pero esperaremos al análisis más adelante en este artículo para explicar detalladamente las razones por las que creemos que en efecto estamos ante un bolaño de artillería.

Fue encontrado en el pequeño departamento 191 (Fig. 6d), en un lugar donde no parece probable que llegará por lanzamiento desde el exterior de la ciudad en el ataque de época sertoriana. Este ambiente, anexo tanto a la bodega 172, como al anteriormente mencionado 190, cuenta con un importante, y muy específico (es el único espacio de todo el barrio iberorromano en el que no ha aparecido cerámica ibérica), lote de material recuperado sobre su pavimento (Uroz Rodríguez, e. p. a y e. p. b), que incluye 18 monedas ibéricas (mayoritariamente de Cástulo) e instrumental de metal, como un cincel-escoplo (LB 150602), un soporte anular de bronce (LB 150040) o una excepcional lucerna de bronce dorado (LB 150023), y objetos de adorno y militaria, incluyendo diversos anillos de bronce y hueso, una fíbula de tipo omega

\footnotetext{
8 Agradecemos la identificación litológica al Grupo de investigación de Petrología Aplicada de la Universidad de Alicante, dirigido por el Catedrático de Geología Juan Carlos Cañaveras.
} 
(LB 150025) y tres fichas para el juego (LB 150795 a 150797). Además del proyectil, de este conjunto procede también la espuela LB 150020.

\section{ARMAMENTO DEFENSIVO ACTIVO}

24. Umbo de Escudo. N. Inv. LB 130298. Sector 18. Calle 1. Campaña 2008. Fig. 7e.

Umbo de escudo bivalvo en hierro completo, con sus dos valvas. Se trata de un ejemplar grande, que con sus $30,4 \mathrm{~cm}$ de longitud supera a las dos piezas ya catalogadas en contextos del s. II a. C. Prácticamente completo, falta solo parte de la aleta lateral de la pieza "hembra". No se aprecian ni siquiera tras la limpieza los orificios de fijación.

Como ya se ha analizado en los ejemplares anteriores, se trata de una pieza del tipo A1.2 en la clasificación de García Jiménez (2012: 203)9 . Se caracteriza porque las dos valvas no son idénticas, sino que una de ellas, "macho", tiene un reborde longitudinal plegado que cubría la spina de madera del cuerpo del scutum, y también el borde de la otra pieza, añadiendo homogeneidad y solidez al conjunto. La llamativa ausencia de remaches para fijación, que ya hemos anotado en muchas otras piezas de este tipo tanto en Libisosa como en otros lugares, plantea problemas, ya que la solución de encolarlas al cuerpo del escudo (García y Quesada, 2014: 21) parece más pesada, engorrosa y con un resultado menos sólido que el sistema de grandes clavos mucho más habitual en otros los otros umbos de escudo oval, sobre todo en el ámbito del nordeste y en todo el mundo galo.

En esto es similar a la pieza LB 145429, y a la mayoría de las piezas de la península ibérica, como las de El Hinojal (Cádiz), Pozo Moro (Albacete), el Romazal 143 (Cáceres). Es posible que oros umbos de los que solo se conserva una valva (como en Libisosa el tercer ejemplar, LB150993) fueran del mismo tipo, al faltar la pieza macho.

Dimensiones: Lg. Mx.: 30,4 cm; An. Mx. (con las valvas superpuestas): 17 cm; Gr. chapa Fe: $0,15 \mathrm{~cm}$; Altura umbo centro: $7 \mathrm{~cm}$.

Como analizaremos luego, la habitual cronología muy antigua que se atribuye a los umbos bivalvos fusiformes en el ámbito celta norpirenaico es ya insostenible en la península ibérica, sobre todo con la adición que suponen los tres ejemplares de Libisosa, claramente datados entre s. II-75 a. C.

\section{Manilla de escudo. N. Inv. LB 150743. Sector 18. Calle 3. Campaña 2015. Fig. 9a-c.}

Manilla de escudo de aletas en lámina de hierro. Creada a partir de una gran chapa metálica aproximadamente romboidal de unos $86 \mathrm{~cm}$ de longitud y $0,1 \mathrm{~cm}$ de grosor, a la que se practicaron cuatro cortes perpendiculares al eje mayor, dos a dos separados por $9 \mathrm{~cm}$ en la zona central, sin llegar a cortar del todo la pieza. Las partes parcialmente recortadas de la chapa se plegaron, enrollándolas sobre un soporte de sección circular, probablemente de madera, de unos $2 \mathrm{~cm}$ de diámetro, creando un asidero o empuñadura (no embrazadera) de $9 \mathrm{~cm}$ de holgura, más que suficiente para una mano robusta. Los laterales de la chapa recortada se plegaron a su vez hacia las aletas, para evitar herir con su borde afilado la mano o muñeca el empuñar la manilla. Las dos aletas resultantes, triangulares, con una anchura máxima en la base de 10 $\mathrm{cm}$ y una longitud de poco más de $38 \mathrm{~cm}$ cada una, forman la superficie para sujetar la empuñadura al cuerpo del escudo, y de paso, mediante sus numerosos remaches, reforzar la unión de su tablazón y fieltro o cuero o tela encolada. Además, en la manilla se sujetan, atravesando también la madera, unas grapas — que Cuadrado (1989) llamó, con acierto, "gusanillos" por

9 Ver también García Jiménez y Quesada (2014) para una actualización del estado de la cuestión. 
a

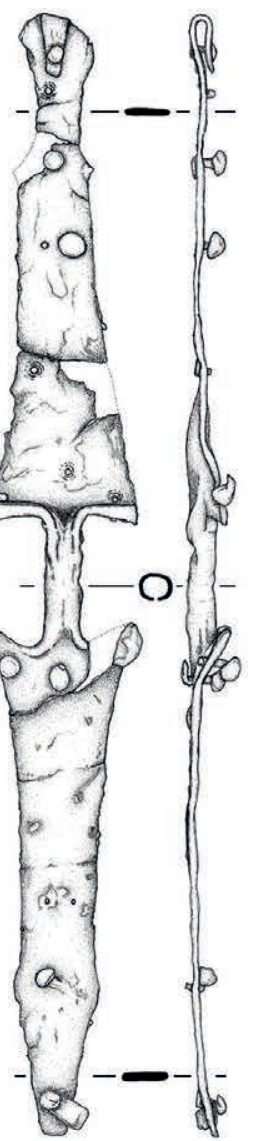

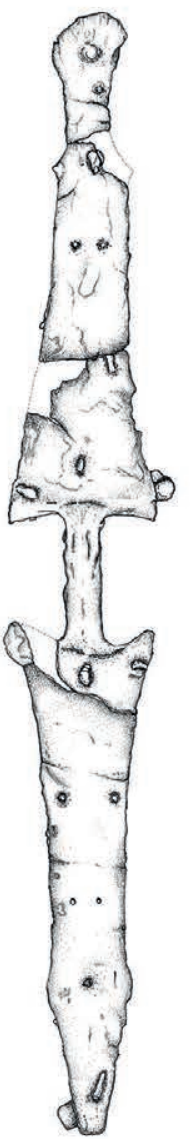

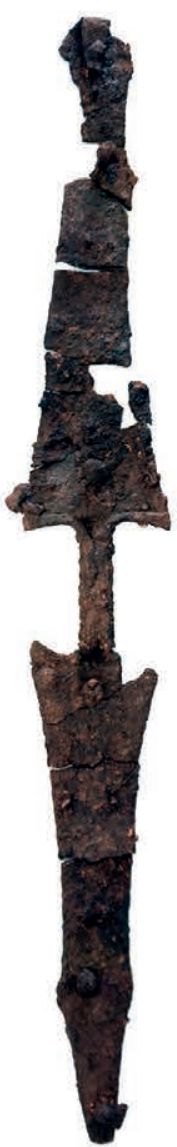

b
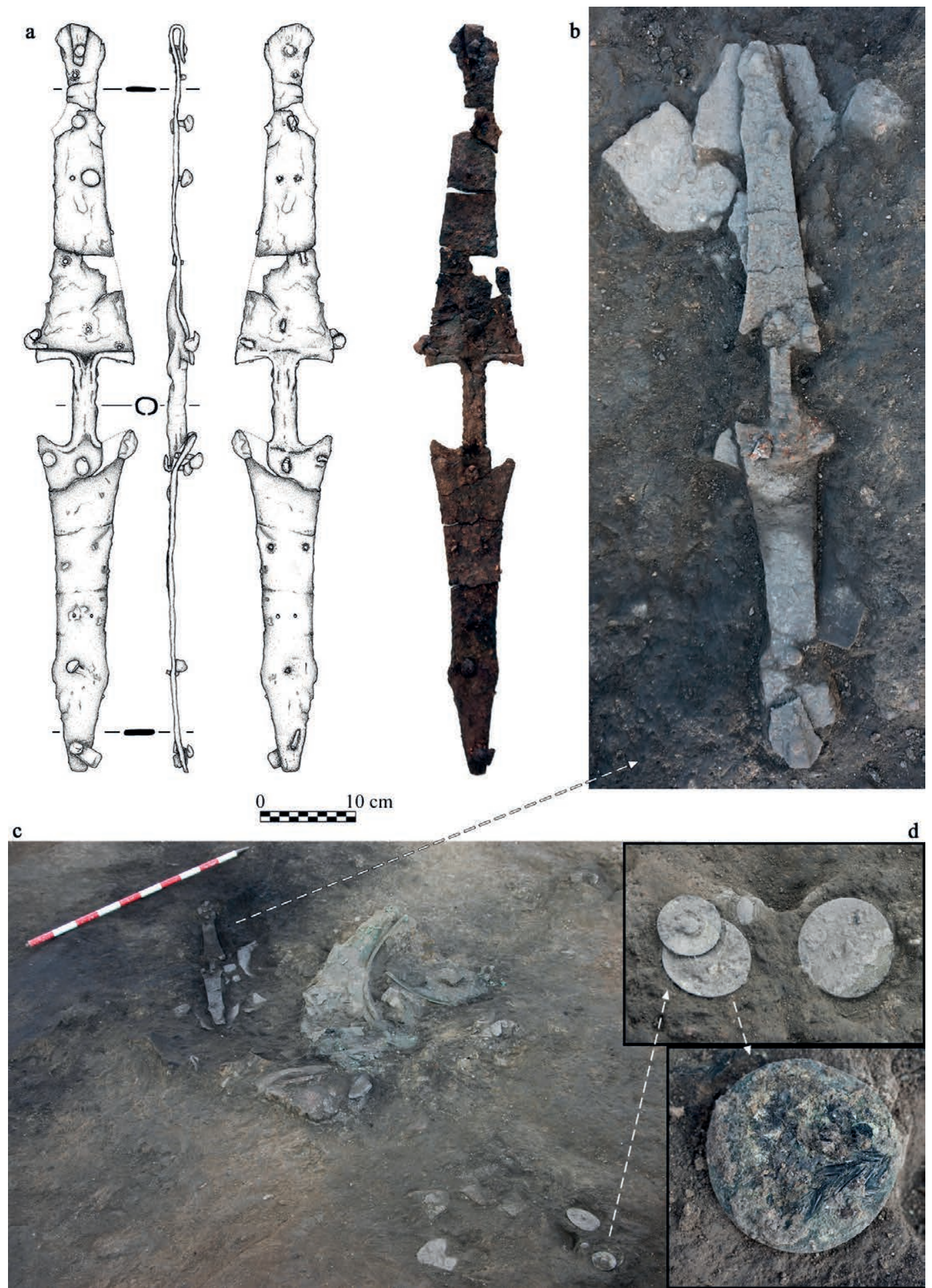

Figura 9. Armamento defensivo activo. Manilla de escudo LB 150743: a. dibujo y fotografía; b. imagen de detalle del hallazgo; c. imagen del hallazgo sobre la calle 3 junto a las fáleras: d. detalle de las fáleras y de LB 150745 con restos orgánicos adheridos. Fotografías: Héctor Uroz. Dibujos: Nora Hernández. 
su apariencia exterior-, y que servían para mantener unas anillas móviles a las que se fijaba la correa de suspensión (gr. telamon) que servían para colgar el escudo de los hombros para el transporte, o de un gancho en una pared en su caso. La estructura completa puede verse en diagramas en Quesada (1997a: 490, fig. 286).

Dimensiones: Lg. Mx.: 78,9 cm; An. Mx. Hj.: 10,5 cm; Gr. Mx. Hj.: 0,1 cm; Lg. Aleta: 38 cm: LIE: $9 \mathrm{~cm}$.

La combinación de clavos de cabeza hemisférica que fijaban la manilla al cuerpo del escudo es peculiar. En cada aleta se fijaron primero tres clavos (o, en la actualidad, sus orificios, ya que no siempre se conservan) alineados en la base de cada aleta; dos más unos $10 \mathrm{~cm}$ hacia la punta, cerca de los bordes de la aleta. A otros $10 \mathrm{~cm}$ de distancia, hallamos otros dos orificios en el centro de la aleta y próximos entre sí, que marcan probablemente el lugar donde se fijó la anilla móvil para el telamon o correa de suspensión. Un poco más hacia la punta, otro clavo grueso con cabeza redondeada en el centro del eje de la aleta; y finalmente, casi en la punta, otro gran clavo. De este modo la manilla férrea, aparte de los clavos para la correa, estaba fijado a la madera por siete clavos en cada aleta, catorce en total.

La chapa de cada aleta tiene unos característicos salientes hacia los extremos distales. Y uno de los rasgos más llamativos es que el extremo de una de las aletas está plegado sobre sí mismo, abrazando en origen el cuerpo del escudo, como si la aleta hubiera sido forjada demasiado grande y hubiera que ajustarla. El espacio hueco que deja la lámina plegada en el extremo nos proporciona, por un lado, el diámetro exacto del escudo, $78,5 \mathrm{~cm}$, dato que es imposible conseguir en la mayoría de las manillas, que no se pliegan y en las que es imposible determinar a qué distancia del borde de madera del cuerpo del escudo llegaban (¿un palmo? ¿un centímetro?).

Por otro lado, ese plegado nos proporciona el grosor original del escudo en el borde, unos $0,6 \mathrm{~cm}$. En cambio, los clavos repartidos por la aleta nos indican que el escudo en la parte central era más grueso, unos 0,7 a $0,9 \mathrm{~cm}$. Este adelgazamiento del escudo es normal en otras piezas conocidas, y servía para aligerarlo y mejorar el control y equilibrio. En la otra aleta no se aprecia este pliegue, sino que la chapa está rota y muestra una reparación con una pletina remachada, quizá porque un golpe dañó la disposición original. En realidad, la manilla presenta varias trazas de reparación y la multiplicación de remaches y clavos que hemos descrito puede deberse a nuestro juicio a añadidos posteriores a su disposición inicial.

En la parte interior de la manilla, la que se fijaba al cuerpo del escudo, no sobresalen los referidos "gusanillos" que serían visibles al otro lado de la madera, quizá perdidos o sustituidos por su sistema más sencillo. Pero sí quedan los dos pares de orificios a que nos hemos referido antes.

Con todo esto, se puede clasificar esta pieza en nuestro tipo "III" (manilla de aletas), "B" (tres puntos o más de sujeción por aleta, en realidad ahora presenta varios más), "2" (con apéndices salientes en el perfil de las aletas), y "b" es decir, posibles dos pasadores para "gusanillos" por aleta, aunque esto es discutible. En conjunto, el tipo resultante sería IIIB2b (Quesada, 1997a: 500-502, figs. 290 y 291).

Esta manilla se empleaba para escudos circulares, en este caso de gran tamaño, bastante más de los dos pies (unos $60 \mathrm{~cm}$ ) que describen algunas fuentes como Estrabón $(3,3,6)$, pero no inusitado. Todo esto será analizado más adelante.

La pieza apareció directamente sobre el pavimento de la calle 3 (Fig. 9c-b), asociada a las tres fáleras (LB 150745, 150746 y 150747), así como a un ronzal o narigón de bronce (tipo 2 de Garcés, 2007) para fijar en el hocico o en el barboquejo del caballo para guiarlo a pie, similar al ya publicado, encontrado en la estancia 6 del "edificio oligárquico" 127 (Uroz Rodríguez, 2012: 290-293, fig. 229e). 


\section{ARMAMENTO DEFENSIVO PASIVO}

\section{Casco. N. Inv. LB 130376. Sector 18. Dpto. 174. Campaña 2009. Fig. 10a-c.}

Casco de hierro de tipo genérico Montefortino, completo pero sin carrilleras. Deformado por presión (algo aplastado) en el eje anteroposterior; cubrenucas deformado en consecuencia. Borde inferior no engrosado, sino plegado hacia el interior, regruesando el borde y evitando así un filo cortante. Huella de gran golpe con objeto romo en el parietal izquierdo. Remate superior macizo.

En el cubrenucas no se ven señales de la habitual placa con lazada para la correa de barboquejo. Tampoco hay señales de las bisagras para carrilleras. En la parte inferior de la calota, sin embargo, encima del borde regruesado, se aprecian dos pequeñas perforaciones en un lateral, separadas por $2,5 \mathrm{~cm}$, que pudieron servir para algún tipo de barboquejo o, con mucha menor probabilidad, para sujetar carrilleras.

Remate superior sin huellas de decoración (ovas...); guardanucas sin decoración; tampoco hay huellas de sogueado en el borde. El casco no presenta señales de haber estado decorado.

Dimensiones: La deformación del casco impide tomar medidas precisas, pero en el eje anteroposterior el Dm. Mx. debía rondar los 28,2 cm, el Dm. Mn (lateral): $18 \mathrm{~cm}$; Altura: 19,7 $\mathrm{cm}$ (con remate); Peso: $1540 \mathrm{gr}$.

El casco es muy pesado, incluso tras su limpieza y restauración. Con 1540 gramos, está muy por encima de los valores para estos cascos que, en sus variantes tardías de los siglos II-I a. C. (incluyendo el tipo Bugennum o Robinson C), sin carrilleras, nunca sobrepasan los 1000 gr y a menudo oscilan entre los 700-900 gr. Solo los modelos antiguos de c. 350-250 a. C. (Montefortino Robinson A), con carrilleras y grosores de chapa de 2-3 mm llegan a los 1900$2000 \mathrm{gr}^{10}$. Por tanto, el casco de Lezuza es extraordinariamente pesado. El mayor peso específico del hierro forjado con respecto al bronce $\left(7,9 \mathrm{gr} / \mathrm{cm}^{3}\right.$ frente a $\left.7,4 \mathrm{gr} / \mathrm{cm}^{3}\right)$ no justifica esta diferencia, pero sí que el grosor de la chapa de hierro (que no es medible por estar hinchado y exfoliado) debía ser mucho mayor de lo habitual en los ejemplares de bronce tardíos.

La ausencia de carrilleras y el metal empleado aleja este casco de lo que podemos habitualmente esperar para un contexto de legionarios romanos. Volveremos sobre ello en el análisis.

El casco se recuperó (¿depositó?) en el interior de un hogar de un pequeño departamento $\left(6 \mathrm{~m}^{2}\right.$ ), numerado como 174 (Uroz Rodríguez, 2012: 298-302; e. p. a y e. p. b), que está a nivel de las calles 2 y 3 , y sus estratos de destrucción son perfectamente contemporáneos a la destrucción sertoriana. En su interior se apilaban algunos objetos excepcionales, junto a otros (ibéricos) mucho más comunes. En ese hogar, de considerables dimensiones para lo reducido del ambiente, tuvo lugar presumiblemente algún tipo de ritual, asociado a un conjunto de morillos y asadores de hierro y restos óseos, y en todo caso recuerda de algún modo a la lectura que hicieron I. Grau y R. Olmos del dpto. F-1 de La Serreta (Grau et alii, 2008: 27-28), de similar tamaño, y que habría constituido una suerte de tesaurización con la intención de ostentar y conservar, combinando cerámicas más comunes con piezas extraordinarias, agrupando así las bases materiales de la pervivencia del grupo aristocrático. Por razones obvias, resulta imprescindible subrayar que en este mismo habitáculo se recuperó el vaso figurado de la "crátera de la monomaquia", que muestra a dos guerreros iberos en combate, ataviados con sendos cascos de tipo Montefortino con correas para barboquejo (Uroz Rodríguez, 2012: 317-321, 343-345; 2013) (Fig. 10d), la vez en que se muestran con mayor claridad en el repertorio vascular ibérico (Quesada, 1997a: 554).

10 Vid. la tabla que compilamos en Graells et alii, 2014: 156, Cuadro 1, creado a partir de los datos homogéneos de la Col. Guttmann, proporcionados en Junkelmann, 2000 

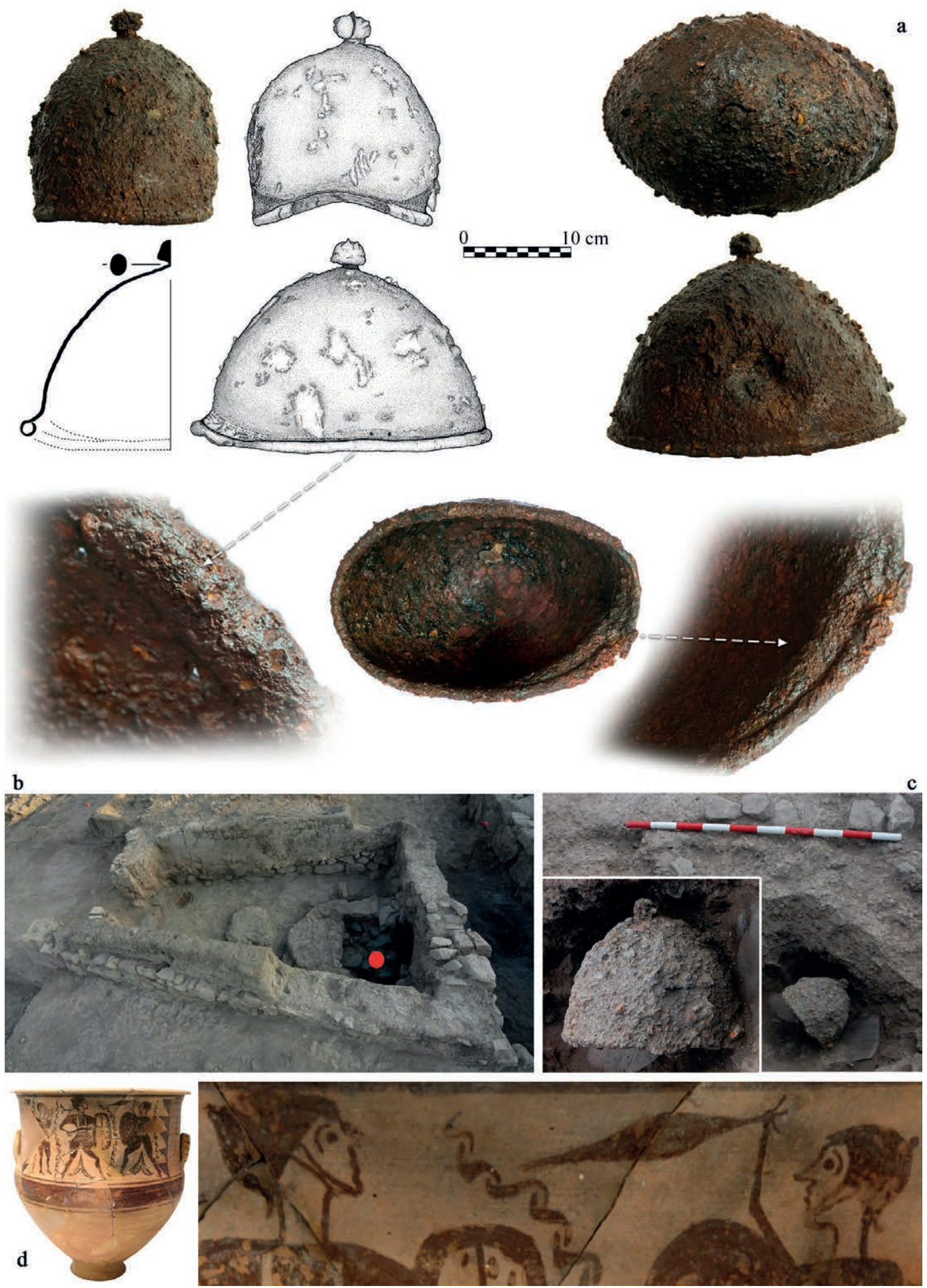

Figura 10. Casco de hierro de tipo Montefortino LB 130376: a. dibujo y fotografías e imágenes de detalle de orificios y pliegues internos; b. dpto. 174. al término de su excavación con indicación del lugar de aparición del casco en el hogar; c. imagen del hallazgo; d. "crátera de la monomaquia" hallada en el dpto. 174 con detalle de los guerreros con casco. Fotografías: Héctor Uroz. Dibujos: Nora Hernández. 


\section{ELEMENTOS DE MONTA Y CONTROL DEL CABALLO}

27. Pieza de cabezada metálica para équido. N. Inv. LB 102751. Sector 18. Dpto. 127-Estancia 5. Campaña 2006. Fig. 11c.

Barra lateral rígida de una quijera o carrillera de hierro, en buen estado y completa, como el ejemplar del s. II a. C. LB 130789 (supra), del que resulta prácticamente idéntico en el tipo. La pieza central, de $24,5 \mathrm{~cm}$, remata en dos anillas —en el mismo plano - que sujetan sendas anillas móviles gruesas. En su centro, y en un eje rotado $90^{\circ}$ sobre el plano de las dos anillas de los extremos, la barra se abre dejando un espacio cuadrangular que pudo sujetar otra anilla móvil u otra pieza de hierro.

Dimensiones: Lg. Mx.: 24,5 cm; diámetro anillas móviles: 4,6 cm; saliente central rectangular: $3,7 \mathrm{~cm}$; orificio interior del ahogadero: $1,4 \mathrm{~cm}$.

Corresponde al Tipo 6 definido en la necrópolis celtibérica de Carratiermes (Argente et alii, 2001: 75 ss. y fig. p. 72), y Grupo B de Quesada (2005: fig. 21). Parte de una cabezada rígida, en concreto carrillera o mejillera. Las anillas móviles de esta severa cabezada enlazarían con las correas de cuero del resto de la estructura (serretón, frontalera) y el orificio del saliente cuadrangular central no serviría para un filete, sino para un ahogadero o una barbada.

\section{Espuela. N. Inv. LB 150020. Sector 18. Dpto. 191. Campaña 2014. Fig. 12g.}

Espuela rígida con cuerpo y acicate de aleación de cobre. Incompleta. Hallada en el ambiente 191. Conserva un lateral completo y la parte central incluyendo acicate. El cuerpo es estrecho y grueso, con sección en forma de "D", la parte plana en contacto con el tobillo, y la externa facetada y decorada mediante una arista horizontal longitudinal que se abre en el centro, en la zona de recepción del acicate, donde surgen protuberancias quizá en forma de palmeta muy estilizada hacia arriba y hacia abajo. El acicate es muy corto. En los extremos, en lugar de la habitual fenestra rectangular u orificio circular, aparecían, solidarios, sendos botones circulares planos donde se podría enganchar la correa de fijación a la pierna.

Dimensiones: Lg. Mx. (c): 7 cm; Lg. Mx. (e): 10 cm (muy abierta); An. Mx.: 0,4 cm; Lg. Acicate: 0,9 cm; Diam. Botón enganche: $1,4 \mathrm{~cm}$.

Se trata, como veremos luego, de un modelo celta prerromano considerado prototipo de otros romanos, y muy escaso en Iberia. Sobre el contexto de la pieza remitimos a lo comentado a propósito del bolaño LB 150039 con el que compartía espacio.

29. Jáquima ('hackamore') metálica de équido. Sector 18. Dpto. 127-Estancia 1. Campaña 2005. Fig. 11a.

Cabezada metálica de bronce (una forma de jáquima metálica) ${ }^{11}$ o hackamore (Littauer, 1969; Lawson, 1978: 140 ss.; Junkelmann, 1992: 24 ss. y abb. 18-21; Simon Ortisi, 2003: 65 ss.). Muy incompleta. A grandes largos se conserva el equivalente de una mitad lateral, con una parte que pasaría al modo de un serretón sobre la nariz del animal, un arranque de anilla, que es clave porque por ella pasaba otra anilla móvil mayor a la que se enganchaban la rienda y la embocadura de un filete, y otra pieza que pasaba debajo de la mejilla, permitiendo una severa acción de palanca o tijera (de ahí el nombre, psalion o "tijera" que suele atribuirse a este tipo de pieza: Anderson, 1961: 60; Littauer, 1969: 291; Taylor, 1975 passim; Hyland, 1990: 140 ss.). A diferencia de la jáquima moderna o el similar hackamore ${ }^{12}$, esta pieza estaba

\footnotetext{
11 Eng. Hackamore; Alem. Metallzaum, Kappzäum; Fr. Cavesson, Gr. psalion.

12 El propio nombre deriva del español "jáquima”, $c f$. Hyland (1990: 142).
} 
destinada a ser, por tanto, usada en combinación con un bocado filete, aunque pudiera usarse independientemente si se deseaba.

Dimensiones: $\mathrm{Lg}$. Mx. (c): $32 \mathrm{~cm}$, que no corresponde a ninguna dimensión funcional real del objeto. An. Mx. Hj.: 1,3 cm.

Se conservan fragmentos de una pieza similar, sin contexto, en la Colección Museográfica de Gilena (Sevilla).
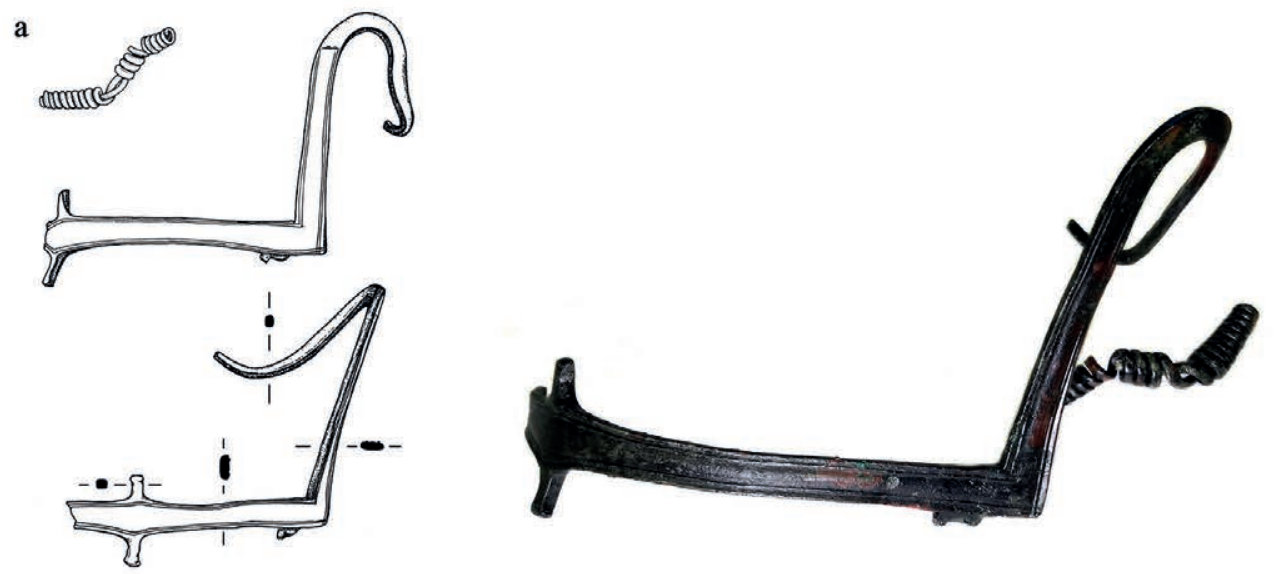

b
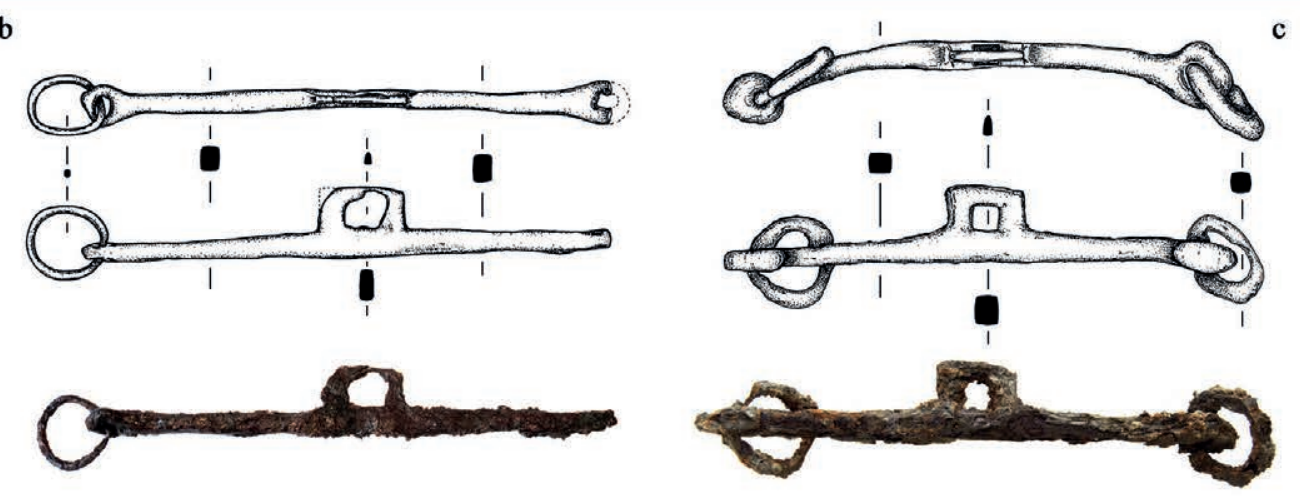

0 $10 \mathrm{~cm}$
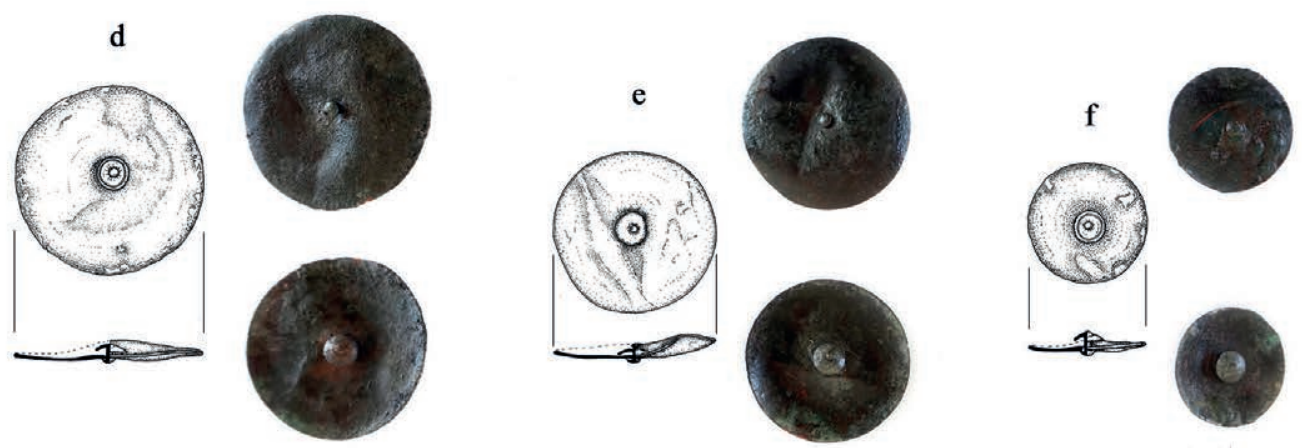

Figura 11. Elementos de monta. Arreos: a. jáquima LB 83687; b. elemento de cabezada LB 130789; c. elemento de cabezada LB 102751; d. fálera LB 150747; e. fálera LB 150745; f. fálera LB 150746. Fotografías: Héctor Uroz. Dibujos: Nora Hernández. 


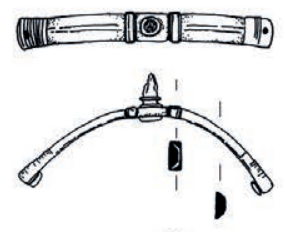

a
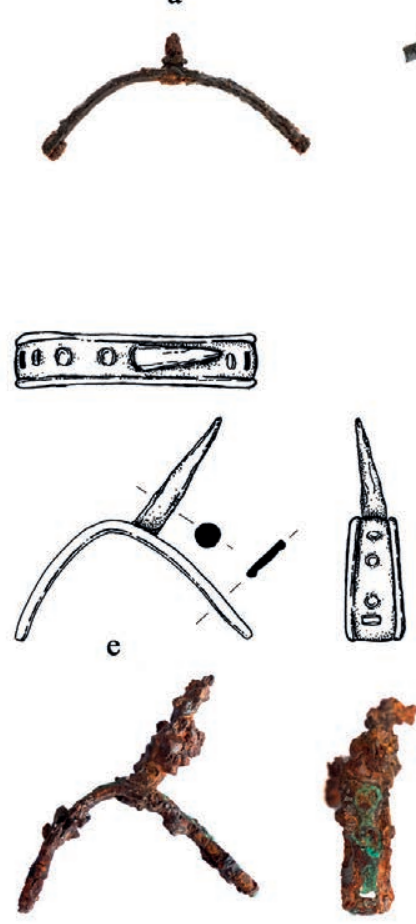

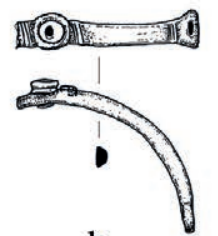

b

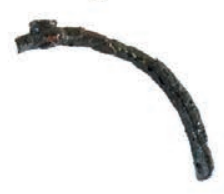

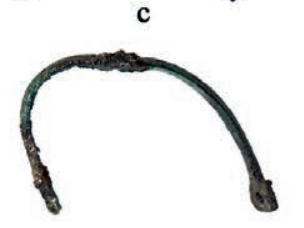

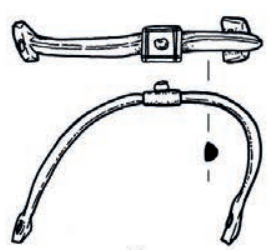

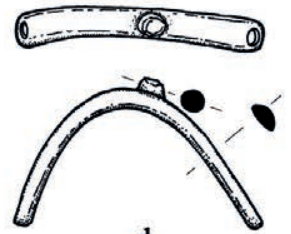

d

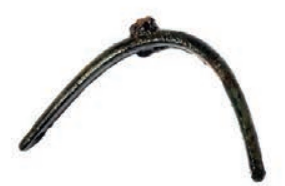

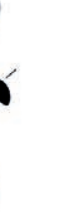

(1)

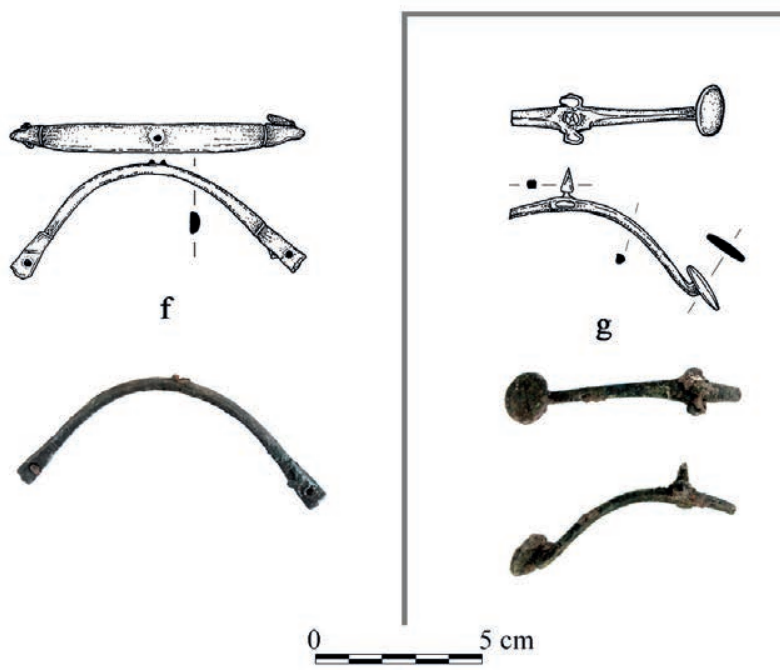

Figura 12. Elementos de monta. Espuelas: a. LB 151092; b. LB 145374; c. LB 152554; d. LB 152580; e. LB 152142; f. LB 149940; g. LB 150020. Fotografías: Héctor Uroz. Dibujos: Nora Hernández.

Destinada, en combinación con el bocado, a actuar como un psalion (gr. "tijera") en caballos que tienden a abrir mucho la boca. Hyland, experta jinete y reconstructora, probó modelos de este tipo de pieza que resultó ser, como ya Jenofonte (De Re Eq. 7.1) afirmaba, extraordinariamente severa y que exige cuidado en su aplicación ( $c f$. Hyland, 1990: 140 ss. siguiendo a Anderson, 1961: 60-61). ${ }^{13}$

Su función es muy distinta, pues, a la de los bozales metálicos que envuelven la boca del animal por completo sin ejercer acción de gobierno (Quesada, 2005: 32-33), y que en el caso de la península ibérica han sido estudiados recientemente por Garcés y Graells (2011), siendo su datación peninsular en general mucho más antigua que la del hackamore de Lezuza, desde el s. IV a. C. aunque hay ejemplares de época romana. Sin embargo, tienen una cierta similitud en la forma en que las barras abrazan la cabeza del animal (comparar Taylor, 1975: 112, abb. 5 con Lawson, 1978: 144 abb. 7).

13 Se le ha relacionado o denominado también como en fr. Cavesson (Anderson, 1961; Junkelmann, 1992: 24), lo que ha lelvado a preisiones en contra recientes, ver Simon Ortisi (2003: 65) para el problema terminológico y la diferencia con el cavesson (fr.). En general el problema terminológico es un campo de minas, sobre todo dada la forma habitual en que se toman préstamos de otros idiomas. No ayuda la similitud funcional inferida de piezas antiguas en comparación con otras modernas, normalmente menos severas, y la consecuente utilización de nombres modernos, 
Puede clasificarse dentro del tipo 5 de Taylor (1975: taf. 59) con la nariguera rematada en piezas estilizadas sobre la forma de "diamante" o "rombo". Sus ejemplares se concentran en Italia y su evolución más ancha en Centroeuropa oriental. También con la variante 5 de Lawson (1978: abb. 6) donde la anilla fundida integral para la rienda y filete es redonda. Corresponde por fin al Grupo III.B.I de la Tesis Doctoral de Simon Ortisi (2003: 207-208) sobre materiales ecuestres de Pompeya y Herculano.

Piezas como las de Lezuza tienen una larga perduración ${ }^{14}$ con una acción de presión/palanca en combinación con un bocado (Anderson, 1961: 60; Hyland, 1990), con variantes tipológicas de detalle, y llegaron en plena popularidad a Pompeya a un momento muy avanzado el s. I d. C., con casi dos centenares de ejemplares (Simon Ortisi, 2003) e incluso al s. II d. C. como en el ejemplar de Newstead (Anderson, 1961: pl. 16). Sin embargo, el origen del tipo no debe ser muy anterior a 100 a. C., y jáquimas o serretones del tipo no están presentes en los contextos republicanos romanos del s. II a. C. como Numancia, donde en cambio si aparecen bocados con desveno que en época imperial suelen asociarse a las jáquimas (Luik, 2002: 93-95 y abb. 56 para el bocado).

30. Fáleras. N. Inv. LB 150745, 150746 y 150747. Sector 18. Calle 3. Campaña 2015. Fig. $11 \mathrm{~d}-\mathrm{f}$ y $9 \mathrm{~d}$.

Conjunto de tres discos (phalerae) de tres diámetros distintos pero estructura idéntica, pertenecientes al mismo lote o conjunto funcional. $\mathrm{Su}$ forma exterior es muy ligeramente convexa, sin llegar ni de lejos a una forma hemisférica o siquiera de escudilla. Por este lado que llamaremos "exterior" sobresale en el centro la cabeza hemisférica de pequeño diámetro $(0,6$ a $0,7 \mathrm{~cm})$ de un remache. Dicho remache, ahora móvil, atraviesa la placa y remata por el otro lado en otra cabeza casi hemiesférica, en este caso mucho mayor (1,5 cm de diámetro). El espacio libre que deja el remache, descontando el grosor de la placa que atraviesa, es de unos $0,25 / 0,3 \mathrm{~cm}$ de espesor, lo que es suficiente para una correa o superficie textil o de cuero de $3 \mathrm{~mm}$ de grosor. De hecho, se encontraron restos orgánicos adheridos a LB 150745 (Fig. 9d).

Las tres piezas muestran señales de golpes que deforman su superficie, desde el lado "exterior" convexo hacia el "interior" cóncavo. No hay decoración de ningún tipo.

Dimensiones: Diam. Mx. 9,1 cm (N. Inv. 150747); 7,9 cm (N. Inv. 150745) y 5,7 cm (N. Inv. 150746). Gr. Hj.: <0,1 cm.

En primera instancia puede pensarse, por forma, tamaño y material, que nos encontramos ante fáleras ecuestres, discos de bronce que la caballería romana (y otras antes que ella) empleaba para enganchar entre sí las correas de cuero (cincha, baticola, petral, etc.) que componían el atalaje del caballo, y que han sido bien estudiadas, para época imperial romana, por M. Bishop (1988), cuyo trabajo — e ilustraciones — han sido muy utilizadas y replicadas (Rabeisen, 1990; Alonso, 1991; Junkelmann, 1992: 12 ss.; Stephenson y Dixon, 2003: 106). Sin embargo, las fáleras de arnés equino presentan siempre en el interior varios y sólidos elementos para fijar y pasar las correas del arnés, que están por completo ausentes (y no se han perdido) en las piezas de Lezuza (Bishop, 1988: 125, fig. 34; 139, fig. 41; 141: fig. 42, etc.; Rabeisen, 1990: 78-79, etc.). Es cierto que estas fáleras son normalmente de época flavia, ni siquiera julio-claudia, y que modelos anteriores pudieron ser más sencillos y livianos. Pero lo cierto es que la estructura de las de Lezuza es más bien ornamental, sin capacidad para sujetar correas sometidas a tensiones y tirones bruscos como los que se producen en arneses ecuestres militares.

También se conocen (aunque suelen ser más tardías, del s. II d. C.) fáleras con tamaños y aspecto similar a las de Lezuza que se interpretan como adornos de los tahalíes y cinturones

14 Agradecemos a R. Graells sus aportaciones cronológicas, bibliográficas e ilustraciones referidas a este tipo de pieza. 
de legionarios, a pesar de que por su tamaño parecen excesivos para esa función (e. $g$. Appels y Laycock, 2007: 86).

Es pues necesario hacer una recopilación de discos de este tamaño y sistema de fijación para analizar bien su posible función. En la Sepultura 477 de la necrópolis ibérica del Cabecico del Tesoro, por ejemplo, se encontraron dos discos de aleación de cobre (uno conservado solo en la mitad) con un remache central muy parecido al de Lezuza, pero con decoración de círculos concéntricos repujados en el borde. La tumba no parece ser posterior a principios del s. III a. C., aunque esto podría ser debatible (Quesada, 1989: vol. II, 24-25, 207).

Los detalles sobre su contexto de aparición los hemos apuntado a propósito de la manilla de escudo LB 150743, junto a la que aparecieron.

\section{INDETERMINADO}

31. Indet. N. Inv. LB 130436. Sector 18. Calle 2. Campaña 2009. Fig. 13c.

Lámina triangular de hierro de $21 \mathrm{~cm}$ de longitud y 7,6 cm de anchura máxima en el extremo proximal (?), sección lenticular.

a
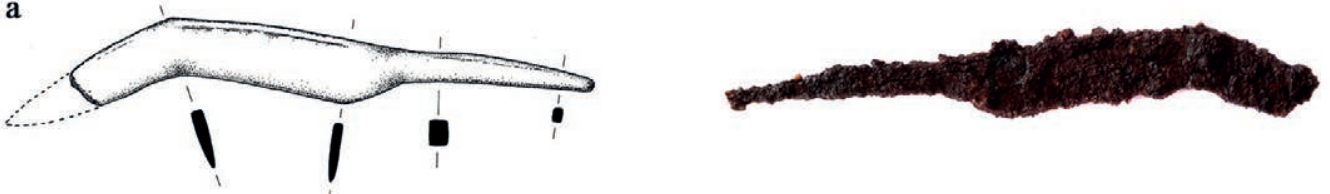

b
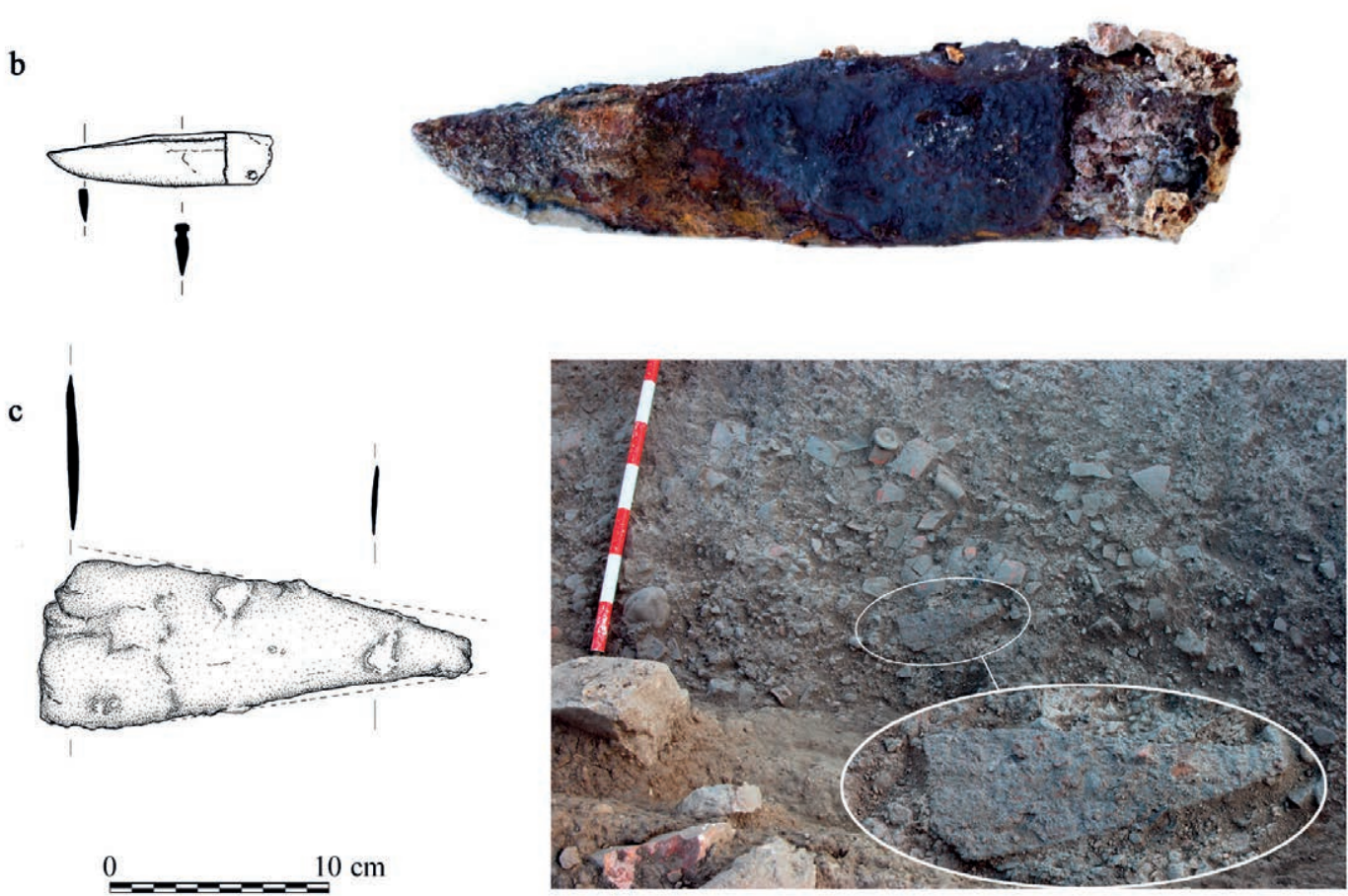

Figura 13. Varia: a. cuchillo LB 152198; b. cuchillo LB 152446 con restos orgánicos adheridos; c. lámina identificada con anterioridad como punta de falcata LB 130436, y aparición sobre la calle 2 del sector 18. Fotografías: Héctor Uroz. Dibujos: Nora Hernández. 
Presentamos aquí a efectos de catalogación y análisis negativo, una pieza, hallada en la Calle 2 junto con un esqueleto femenino que tentativamente se ha descrito como punta de una falcata (De Miguel y Uroz Rodríguez, 2017; Uroz Rodríguez y Uroz Sáez, 2014: 212). Sin embargo, una vez limpiado, analizado y restaurado el objeto debemos descartar esta opción, por varias razones.

El perfil del supuesto dorso de la hoja es demasiado curvo (convexo), siendo entonces el supuesto filo cóncavo, lo que no ocurre en ninguna falcata conocida. La inversa, considerar la parte cóncava como parte del dorso tampoco cuadra formalmente. En segundo lugar, la anchura máxima conservada de esta pieza es de $7,6 \mathrm{~cm}$, mientras que en el medio millar de falcatas que hemos medido la media de anchura máxima es de solo $5,8 \mathrm{~cm}$, un valor muy alejado, siendo la falcata más ancha con diferencia que conocemos de 7,2 cm (Quesada, 1997a: cat. 1451 de Baza, sin restaurar y muy exfoliada y dilatada). En tercer lugar, en la pieza de Lezuza no se aprecia rastro alguno de vaceos: conservándose $21 \mathrm{~cm}$ de hoja, debería en el extremo proximal asomar parte de esas acanaladuras, al menos unos $7 \mathrm{a} 10 \mathrm{~cm}$, ya que los vaceos en las hojas de falcatas de media terminan mucho más cerca de la punta, como mucho a $17 \mathrm{~cm}$ y normalmente a unos 11-13 cm (Quesada, 1997a: 99, fig. 42). En cuarto y último lugar, la sección de la hoja, lenticular más que triangular y muy aplanada, es demasiado plana y no es propia de una falcata en su tercio medio o distal.

\section{ANÁLISIS}

\section{EL ARMAMENTO OFENSIVO}

El conjunto de armamento ofensivo se desequilibra, para lo que conocemos sobre las tácticas militares de los siglos II y I a. C., desproporcionadamente hacia armas costosas y empuñadas, envainables: dos espadas y dos puñales, tres de ellos en contexto del s. II a. C., junto a una sola espada de época sertoriana.

Las dos espadas son especialmente significativas, y tipológicamente se adecúan bien a la secuencia de evolución formal que se ha ido estableciendo. Estamos ante ejemplares del gladius hispaniensis (sobre el término: Quesada, 1997c; 2007) o de su prototipo inmediato. Dado que ese nombre se asocia indistintamente en según qué ocasiones a la morfología o al usuario, se provoca confusión. En realidad, en pleno s. II a. C., por la pieza misma no puede deducirse si en su último uso la empuñó un hispano resistente contra Roma, un hispano aliado de Roma, o un legionario romano (Quesada, 2007: passim para el problema). Eso solo lo puede fijar el contexto, y no siempre. La morfología de las piezas de Libisosa, y sus paralelos, es la de una espada todavía hispana (la primera) y cercana a los ejemplares romanos conocidos (la segunda), pero en cuanto latinizamos el nombre y la ponemos en manos de un romano, se convierten en gladii hispanienses. Es el problema de la permeabilidad de este tipo de arma en el s. II a. C. ${ }^{15}$ Sobre todo conviene estudiar reposadamente la hasta ahora mejor síntesis y refinamiento del modelo de Quesada a cargo de Gustavo García Jiménez (2012: 147-164), sobre todo en lo referente a la cuestión de la vaina, que en todo caso no ha aparecido en ninguno de los dos casos. Visiones alternativas, pero a nuestro juicio erradas, se dan sobre todo en Rapin (2001a:

15 Sobre todo ello, desde la primera identificación moderna por F. Quesada del prototipo de la espada romana tardorepublicana en las variantes hispanas tardías de la espada de La Tène I, ver fundamentalmente Quesada (1997b, 1997c) y la aceptación explícita de Connolly (1997: 49-56), de Poux (2008: 316 ss.) o de Bishop (2016: 10) y Kavanagh (2016: 152-155); y con varios matices de Pernet (2010: 53 ss.) o Ble Gimeno (2015: 118-133). 
40 ss.) o Miks (2007: 19-51) para quien las armas de más de $60 \mathrm{~cm}$ de hoja serian spathae de caballería; y James (2011: 79 ss.) todavía basado en estudios obsoletos ${ }^{16}$.

Los puñales, un arma de representación y estatus a lo largo de la historia de la panoplia ibérica (Quesada, 1997a: 302 ss.), y comparativamente rara hasta mediados del s. II a. C., están con sus dos ejemplares (ambos del s. II a. C.), bien representados en Lezuza. Los dos corresponden al tipo bidiscoidal hispano del s. II a. C. Aunque no hay fuentes literarias explícitas, sí las hay indiciarias (Kavanagh, 2016: 162, n. 46), y desde luego la evidencia tipológica hace prácticamente seguro que el pugio tardorrepublicano/altoimperial temprano romano derive del modelo celtibérico, extendido en fechas muy tardías al mundo ibérico fronterizo en Cuenca (Lorrio y Sánchez de Prado, 2014: 265) o Cataluña (Sanmartí, 1994, Turó del Vent; Ble, 2015: 140-141, Puig Ciutat). Esta adopción romana, que parte de toda una tradición bien conocida arqueológica y documentalmente (Quesada, 2007), se acepta generalmente desde principios del s. XX (Sandars, 1913: 64) y hasta hoy (e. g. Quesada, 1997a: 300 ss.; Kavanagh, 2016: 155 ss.; Ble, 2015: 133 ss., etc.). En realidad, hoy se tiende a pensar que en la configuración del puñal romano intervinieron tanto el tipo bidiscoidal celtíbero con empuñadura facetada en aristas (Kavanagh, 2008: 155-157) y el puñal "de filos curvos" (De Pablo, 2012; 2018). Desde la perspectiva romana el cuadro es quizá un poco más complejo (Fernández et alii, 2012).

Más problemático es fijar un momento de adopción. A nuestro juicio (Quesada, 2007: 387391), esta debió ser gradual, probablemente entre las guerras numantinas y las sertorianas (c. 133-c. 75 a. C.), comenzando probablemente por la "captura" como botín de algunos puñales por parte de legionarios, su lenta generalización privada, y finalmente la adopción y producción romana, probablemente en torno al final de las guerras civiles cesarianas y al comienzo del gobierno de Octavio. La estela de Minucio Lorario (Keppie, 1991), de época cesariana, muestra un modelo de tipo hispano en manos de un veterano centurión romano que había luchado en Hispania. Solo más adelante la "romanización" del puñal y su transformación hizo surgir rasgos ya propiamente romanos en todos los elementos del pugio, transformación que comienza en ejemplares como el de Oberaden (Alemania, de c. 11-7 a. C.) (Scott, 1985: 185, n. 3) o el de Titelberg (Lux., de c. 30 a 10 a. C.) (Scott, 1985: 185, n. 1; Vanden Berghe y Simkins, 2001-2002), todavía próximos a los modelos celtibéricos, hasta el punto de que Kavanagh (2008: 59) plantea, con bastante buen criterio, que la pieza de Titelberg no sea de fabricación romana sino hispana, en la tradición local secular. Un modelo casi idéntico de adopción muy gradual aunque por "etapas" más cerradas es el que ha presentado Kavanagh (2016: 160). ${ }^{17}$

Aunque se han incluido en el catálogo dos cuchillos grandes y pesados, muy diferentes de los habituales cuchillitos afalcatados de hoja estrecha y liviana, no se pueden considerar armas en sentido estricto. Sin embargo, el cuchillo de gran tamaño puede ser empleado como arma de fortuna, al igual que podones, hoces y otros instrumentos agrícolas, caso por ejemplo del contexto sertoriano del año 74 a. C. asociado a una matanza de prisioneros en la toma de Valentia, donde aparecieron varios podones en contexto bélico (o más bien de matanza), quizá usados - en la propuesta de sus excavadores - para desmontar jinetes, aunque no necesariamente solo para ello (Ribera, 1995; Alapont et alii, 2010; Ribera, 2014: figs. 11-12). Sin embargo, y a diferencia del caso de Valencia, nada permite en Libisosa asociar los dos grandes cuchillos

16 Otros trabajos de cita obligada para presentar un panorama equilibrado son los referentes a nuevos gladii republicanos relativamente antiguos hallados en diversos lugares, fundamentalmente: Istenic (2000), Stiebel (2004) y Davoli y Miks (2015).

17 No resulta especialmente útil para esta cuestión, por recoger básicamente las opiniones de E. Kavanagh y C. Fernández, a veces confusamente interpretados o sin citarles en bibliografía — aunque si en notas aisladas-, el breve libro de M. Saliola y F. Casprini (2012). 
a un empleo bélico. Se incluyen aquí, pues, a efectos sobre todo de catalogación y de cara a posibles hallazgos futuros más expresivos.

Al contrario de lo que ocurre con las armas envainables, las armas de asta, las más frecuentes en combate, están mucho mejor representadas en el s. I que en el II a. C. (donde están ausentes). Y de entre ellas, los pila grandes y pesados de tipo probablemente romano predominan (con tres ejemplares) sobre la solitaria moharra de lanza y el único regatón. Mientras que la lanza es de un tipo genérico, al igual que el regatón, los tres pila constituyen un buen motivo para manifestar la "romanidad" del conjunto de la panoplia.

Convencionalmente se distinguen por su sistema de enmangue o enastado dos grandes familias de pila republicanos y altoimperiales: ${ }^{18}$ mediante lengüeta plana embutida en la madera y fijada con remaches; o mediante cubo hueco en el que se embute el asta de madera (cf. Connolly, 1997; 2001-2002; Quesada et alii, 2015: fig. 4, 321-326).

Suele denominarse el tipo de cubo como "ligero" frente a los modelos de lengüeta normalmente considerados los "pesados" (Vicente et alii, 1997: 181; García-Dils y Menéndez Argüin, 2006; Bonacina, 2007; etc.). En realidad, esto deriva de tratar de adoptar los dos modelos principales conocidos de pila romanos a la descripción de Polibio $(6,23,8)$ sobre dos tipos por su grosor (mejor que por su peso), distinción también recogida por Dionisio de Halicarnaso $(5,46,2)$.

Sin embargo, hay pila de cubo como este, muy largos y pesados, y otros de espiga o lengüeta como los de Smihel (Horvat, 1997: figs. 3-4; Connolly 1997: fig. 2) o los hispanos de Castellruf (Álvarez y Cubero, 1999) o Albahacas (Quesada et alii, 2015: fig. 3) muy cortos y desde luego mucho más livianos (larga lista de ejemplos ilustrados en Bishop, 2017: 11-14). La independencia de sistema de enmangue y tamaño/peso se hace evidente en los gráficos comparativos (e. g. Connolly, 1997; Quesada et alii, 2015: 324, fig. 6). En realidad, Polibio no hace distinción por el tipo de enastado (solo describe el tipo de lengüeta con sólidos remaches: Pol. 6,23,11), aunque su texto es confuso en las dimensiones y ha dado lugar desde siempre a sesudas e inconclusas discusiones (Walbank, 1957: 705 y hasta Bishop, 2017: 11-15).

Estos pila en su variante de cubo, pues, aunque de tipo frecuentemente encontrado en contextos romanos, pueden haber sido también empleados por iberos ${ }^{19}$, y en todo caso corresponden a un modelo arrojadizo pesado. Las variantes de lengüeta plana suelen aparecer sobre todo en contextos militares claramente romanos, aunque no faltan en asentamientos ibéricos, caso de Castellruf. En principio, la hipótesis más prudente sería atribuirlos a romanos o auxiliares itálicos pero, en un contexto del s. I a. C., no se puede excluir su empleo, incluso generalizado, por iberos aliados o enemigos.

Las puntas de flecha de formas sencillas en la Edad del Hierro peninsular y época de la conquista romana son notoriamente difíciles de atribuir cronológica, tipológica y culturalmente, sobre todo si proceden de contextos de prospección (Quesada et alii, 2015: 355).

En concreto, la forma plana con aletas laterales y pedúnculo aparece en bronce ya en la Prehistoria: (corresponde por ejemplo al tipo C1 de G. Ruiz Zapatero para el Bronce Final del Nordeste (Ruiz Zapatero, 1983: 930-937; tabla-resumen en Quesada, 1997a: 459, fig. 277). Perdura durante todo el Hierro I (Kaiser, 2003, tipo II B 1 PÂ, muy extendido por toda la mitad oriental de la península ibérica en Bronce Antiguo y Medio). E incluso en el campo de batalla de Las Albahacas/Baecula, cuyo conjunto está bien fechado a fines del s. III a. C., aparece una punta muy similar pero en aleación de cobre, correspondiente al tipo IIIB de Kaiser (2003).

18 Existe alguna otra variante republicana o gala de espiga — con o sin virola — tan infrecuente que no la discutimos aquí, cf. Connolly (1997).

19 Discusión en Quesada, 2007: passim y tabla comparativa en fig. 382 y Quesada et alii, 2015: 317 ss. sobre las muy resbaladizas atribuciones de armas antiguas a contendientes concretos. 
En principio, estas puntas se datarían entre el Bronce Medio y el Hierro I, pero hay un número creciente de casos en que modelos similares aparecen en contextos romanos, como en el bien datado del s. I a. C. del oppidum de La Cloche, en la desembocadura del Ródano (análisis más detallado en Quesada et alii, 2016: 375-376). En el caso de la punta de Lezuza, además, su manufactura en hierro y su excelente contexto estratigráfico llegan a concluir que este tipo de punta estaba en uso a mediados del s. II a. C. Tampoco es una rareza absoluta, dado que hay puntas de flecha en hierro con aletas entre el s. IV y el II a. C. en yacimientos ibéricos (Quesada, 1997a: 459 ss.); y además tenemos entre el gran conjunto cesariano de puntas de flecha de pedúnculo algunos modelos próximos al de Lezuza (Sievers en Rouillard, 1997: 63, n. 57). De hecho, hemos clasificado recientemente (Quesada y Kavanagh, e. p.) este tipo como C2 (de espiga, triangular bilobulada, con aletas,) aunque ciertamente la pieza de Libisiosa presenta el obstáculo de su pedúnculo plano laminar y bastante ancho, inhabitual.

La rareza de puntas de flecha (solo dos ejemplares en hierro, atípicos, del s. II a. C.) no sería llamativa en un poblado exclusivamente ibérico, pero si es llamativa en el s. II a. C. y más aún en un posible contexto de asalto en época sertoriana. Cabría esperar un gran número de puntas bipiramidales ("dardos", "tipo Numancia") que aparecen en cantidades en Baecula o Numancia, y también aisladamente en contextos como el Cerro de la Cruz en Almedinilla (Córdoba) que excavamos. También cabría esperar la presencia de otros tipos en hierro claramente romanos.

Lo mismo ocurre, añadimos, con la ausencia completa de glandes de honda, presentes ya en la Segunda Guerra Púnica en cantidades moderadas (e. g. Baecula, Quesada et alii, 2015) o La Palma (Noguera et alii, 2013), en las guerras celtibéricas (Numancia: Luik, 2002) e incluso en época sertoriana (La Caridad: Vicente et alii, 1997, incluso con elementos de fundición en molde). En esto, como en la escasez de puntas de flecha, e incluso la ausencia de clavi caligares, podemos sospechar que acabarán apareciendo intramuros algunos ejemplares, y que una prospección en las zonas exteriores del oppidum, en zonas proclives a un asalto, darían lugar a su aparición más numerosa.

El problema planteado por el posible bolaño para artillería del dpto. 191 (contexto sertoriano) deriva de tres factores: su ubicación (ya mencionada en el catálogo), su litología y su peso. La cuarcita es una piedra extremadamente dura y molesta de tallar, por lo que lo habitual es el empleo de piedras más manejables, como la andesita volcánica de Cartagena que acompaña a calizas, calcarenitas e incluso conglomerado (Olcina, 2009: 74), o calizas y areniscas (Marsden, 1969: 80-81; Murray, 2012: 155). En la Galia hay ejemplos de piedra volcánica, de caliza, de granito y de basalto (Poux, 2008: 371). Así pues, se conocen bolaños de piedras muy duras y densas como basalto (Murray, 2012: 155), luego no es un argumento suficiente.

Pero el principal problema pareciera ser el peso (580 gr), más incluso que su reducido tamaño (diam. 7,5 cm). El calibre de la artillería antigua de lanza-piedra (lithobolos, ballista) se basa en el peso del proyectil que arroja (Heron Belop. 112-113; Vitrubio 10,11,2, etc.). El sistema estándar de la artillería antigua desde época helenística hasta al menos el comienzo del Imperio romano se basa en la mina ática de 436 gr (Marsden, 1971: xvii). Hay minas más pesadas, como la babilónica de 640 gr, pero hasta los cartagineses, que adoptaron la artillería de los griegos en Sicilia, parecen haber seguido empleando los módulos de la mina ática. Su múltiplo básico es normalmente un múltiplo de minas hasta el talento de 60 minas $(26,2 \mathrm{~kg})$. Por ejemplo, en Rodas los bolaños están marcados y sus pesos se ajustan a la mina ático/euboica (Marsden, 1969: 82-83). En Cartago la mayoría de los miles de proyectiles defensivos hallados (i. e., pensados para ser arrojados por grandes máquinas desde las torres de la muralla) pesan entre 15 y 17 minas (por encima de $6-7 \mathrm{~kg}$ ). Los proyectiles menores pesan en torno a 8 minas (3,5 kg) (Marsden, 1969: 80-81). En Pérgamo los calibres son similares a los de Carta- 
go, y están muy estandarizados (Campbell, 2003: 20-21). De hecho, en la tabla compilada por Campbell se aprecia que los calibres oscilan entre las 3 minas $(1,3 \mathrm{~kg})$ y los monstruosos 3 talentos o 180 minas $(78,6 \mathrm{~kg})$. Pero los calibres de menos de 8 minas $(3,5 \mathrm{~kg})$ son una verdadera rareza. Con todo, el hallazgo de un modiolo o soporte de resorte en el cabo Sunio muestra la probable existencia de máquinas con un calibre de solo dos minas (Williams, 1992; Ble, 2015: 242). Así, las tablas compiladas indican que es posible hallar pesos por debajo de dos minas (Murray, 2012: 158, table 5.2).

¿Dónde deja esto la pieza de Lezuza? Muy por debajo de los calibres más pequeños bien documentados, y fuera de la metrología, ya que ni pesa una mina ni dos, quedándose con sus 580 gr también lejos de 2 minas (870 gr). Pero hay más cuestiones a debatir, entre ellas la realidad arqueológica.

Los romanos emplearon tras la conquista de Cartagena por Escipión en 210/09 a. C. una gran cantidad de máquinas cartaginesas capturadas, enumeradas por Livio en términos de sus tamaños (Liv. 26,47) que se ajustarían al patrón helenístico. Sin embargo, con Vitrubio ya en época augustea, vemos descripciones de máquinas expresadas en términos de metrología romana y no griega, esto es, la libra de 327,5 gr (se habla por ejemplo de ballista centenaria, i.e, que arroja un proyectil de 100 libras, $32,75 \mathrm{~kg}$ : Marsden, 1971: xviii). Prueba de la gradual imposición del sistema metrológico romano sobre el griego es la existencia de al menos un bolaño con inscripción "bilingüe", fechado en el 23 a. C. con el peso dado ya en libras, que procede de Qasr Ibrim, en Egipto (Wilkins, 2003: 63; 2017: 116 ss.). Cuando en este mismo momento Vitrubio habla de los calibres (en función del peso, como hemos visto), se refiere a los módulos griegos, aunque él hace una transformación a libras romanas $(10,11,2)$. Lo que nos interesa aquí es que incluso el calibre más pequeño que proporciona no es una libra, sino dos $(10,11,3)$, esto es, 655 gramos, todavía algo por encima del peso del bolaño de Lezuza, $580 \mathrm{gr}^{20} \mathrm{Sin}$ embargo, la diferencia de 75 gramos entre el modelo más pequeño que un ingeniero romano concebía en época de Augusto y la pieza de Lezuza de sesenta años antes no es insalvable. De modo que cabría concebir que nos encontremos ante un proyectil de artillería de campaña extremadamente liviana, con metrología romana de dos libras cortas.

En conjunto deberíamos ser escépticos en tanto no aparezca más documentación en un contexto más claro; sin embargo, los paralelos peninsulares nos llevan a pensar que estos calibres muy pequeños son más habituales de lo que se cree. En Iberia hay pocos bolaños en contexto arqueológico que hayan sido estudiados. En el nordeste la piedra empleada es caliza o roca volcánica. Un ejemplar irregular, de entre 6 y 7,4 cm procedente de la Neapolis emporitana pesa casi una mina exacta (435 gr), mientras que tres ejemplares de Puigpelat pesan respectivamente 750 gr (Diám. 8,5 cm), 1,25 y $10 \mathrm{~kg}$ (Ble, 2015: 241). En Numancia, en un contexto de mediados del s. II a. C., surge una variación importante. Los ejemplares pesados por Luik (2002: 85-86, tab. 3) tienen diámetros que van de 5,5 a $17 \mathrm{~cm}$, con un peso que sube desde 225 a 4840 gr. Es decir, hay proyectiles aparentemente artilleros con pesos incluso inferiores al de Libisosa. Más aún, y como también ha visto E. Ble (supra) la densidad de la piedra empleada hace que piezas de mismo diámetro tengan pesos marcadamente diferentes, e incluso que una piedra más pequeña pese más que otra más grande. Así, la pieza n. 6 de Numancia (Luik, ibidem) con $9 \mathrm{~cm}$ de diámetro pesa $820 \mathrm{gr}$, mientras que la n. 9, de idéntico tamaño, pesa $400 \mathrm{gr}$, menos de la mitad. ${ }^{21}$ En el Tossal de Manises, en un contexto que puede ir desde época

20 Proyectiles de dos libras se han hallado en contextos romanos, como Masada, s. I d. C. (Rihll, 2007: 291), o Burnswark y Shan Castle en Dumfrieshiere, Reino Unido, con proyectiles de 650 gr (Rihll, 2007: 288 y 291; Wilkins, 2017: 137).

21 Las tablas empleadas en la construcción nos indican, por ejemplo, que una caliza porosa tiene un peso específico de $2400 \mathrm{~kg} / \mathrm{m}^{3}$, mientras que una compacta llega a los $2700 \mathrm{~kg} / \mathrm{m}^{3}$, y que una diorita puede llegar a los $3000 \mathrm{~kg} / \mathrm{m}^{3}$ (https://ingemecanica.com/tutoriales/pesos.html\#piedras). También: http://www.jossoft.com.ar/ARCHIVOS/Pesos\%20Especificos.pdf 
bárquida hasta augustea y más allá, se han encontrado hasta 54 bolaños de diferentes pesos y diámetros, muy variados, entre los 7 y $\operatorname{los} 35 \mathrm{~cm}$, lo que de nuevo da un paralelo bajo para Lezuza. Sin embargo, se ha excavado en buen contexto un lote de siete bolaños de andesita de Cartagena, documentada por analítica (Olcina et alii, 2010). Estos bolaños pesan entre 1 y $2 \mathrm{~kg}$, es decir, en torno a 4-8 minas. Y en el contexto sertoriano de la destrucción de Valentia, contemporánea a la de Libisosa, se documenta, al menos, en la zona de las termas, un proyectil esferoidal de artillería que debe medir en torno a 10/12 cm de diámetro, aunque no conocemos el peso (Ribera, 2013: 132 y fig. 8).

En el contexto galo-romano la útil síntesis de Poux (2008: 371-372) analiza —al igual que hacemos nosotros - otras posibilidades de interpretación para ciertas piedras esferoidales, como ponderales. Pero para las piezas que considera por el contexto como bolaños, deja claro que el rango de pesos habitual oscila entre los 2 y $5 \mathrm{~kg}$. Y los diámetros entre 10 y $30 \mathrm{~cm}$, siendo el peso mínimo de unas 10 libras romanas (hablamos de contextos básicamente cesarianos), esto es unos 3,2-3,7 kg. Sin embargo, su figura 50 muestra que en La Clóche, por ejemplo, hay piezas tan pequeñas como las más pequeñas de Numancia, de $1 \mathrm{~kg}$ o menos.

Dicho todo esto, y en contexto de la campaña numantina: los artilleros romanos, menos ingenieriles y especializados que los de Pérgamo o Rodas ¿se fijaban en el peso exacto de los bolaños, o más bien en el diámetro que encajara en la corredera de sus balistas? Es probable que lo segundo, y de ser así, en Numancia hay varios proyectiles de entre 5,5 y $9 \mathrm{~cm}$ de diámetro y de entre 225 y 820 gr. El bolaño de Lezuza entraría confortablemente en esta horquilla, en su zona media.

Tras todas estas consideraciones, creemos que, en efecto, pese a la piedra empleada y el peso, la pieza de Libisosa puede ser considerada un bolaño de artillería ligera.

\section{ARMAMENTO DEFENSIVO}

No se conservan, como en prácticamente ningún otro contexto republicano o ibérico tardío, restos de armadura, ni siquiera la relativamente común cota de malla legionaria del s. I. Solo la cota de Piquía, recientemente publicada, se sale de esta regla (Quesada et alii, 2019).

En cambio, tenemos una muestra bastante completa de otros elementos de la panoplia defensiva pasiva (esto es, destinada a proteger el cuerpo como última defensa, $c f$. Quesada, 1997a: 549 para el concepto) y activa (capaz de ser desplazada a voluntad del combatiente e incluso de ser usada activamente, como defensa y ofensa, $c f$. Quesada, 1997a: 483; sobre el empleo ofensivo del escudo romano, $c f$. Quesada, 2016: 27 con refs. literarias).

En Libisosa conocemos un ejemplar de casco del tipo genérico Montefortino en hierro. Por su ausencia de decoración, su guardanuca corto y poco inclinado, y su forma relativamente chata, este casco se aproxima a los modelos evolucionados empleados por los legionarios romanos del nuevo ejército republicano desde comienzos del s. I a. C., y que desembocarían en el tipo llamado "Buggenum" (antiguo Coarelli D -1976- y Robinson C -1975-) que muchos (Feugère, 1994: 79-80) prefieren ya considerar diferente del Montefortino, y que en todo caso apareció poco antes de la muerte de César. Sin embargo, la ausencia de carrilleras (incluso de la placa en el borde del casco que suele indicar su presencia originaria) es una característica que, como ya mostramos hace mucho (Quesada, 1997b: 156) es propia de los cascos Montefortino hallados en contextos ibéricos, despojándoles de ellas en todos los casos, como si su empleo les resultara incómodo, perjudicial en combate o inaceptable socialmente.

Pero sin duda lo más llamativo es que el casco esté forjado en hierro. En contextos antiguos y, sobre todo, en el nordeste peninsular, son normales cascos de tipo celta en hierro, con 
guardanuca separado, pero sus fechas son propias del s. IV a. C. (Quesada, 1997b: 154 y fig 7.A). Otros cascos férreos aislados, en cambio, desafiaban en los años noventa del s. XX una explicación completa. García Jiménez volvió sobre ellos (2012: 305 ss.) y de nuevo Mazzoli recientemente (2016: 110-118) en detalle, anotando su heterogeneidad. Aunque el completo estudio de Mazzoli no es siempre fácil de utilizar, queda confirmada la aparición de una tradición de cascos de hierro diferentes de los celtas de guardanuca separado, entre los que incluye ejemplos como Cigarralejo Sep. 478 y el propio casco de Libisosa que nos ocupa. El casco de hierro de la Sepultura 478 del Cigarralejo (analizado por nosotros en Quesada, 1997b: 151, 154 y 160, Pl. 1) se data por el ajuar de su contexto en el 375-350 a. C. y, sin embargo, en su momento nosotros consideramos que - de no ser por el contexto- podría tratarse de un tipo Coolus "pesado" sin remate de mediados del s. I a. C., pero en hierro (Feugère, 1994: 41). García Jiménez (2012: 306-307) y Mazzoli (2016: 111) reexaminan el casco en función de paralelos itálicos y consideran que en efecto podría ser antiguo y no emparentar con el de Lezuza. Para Mazzoli (2016: 111-112) el casco de Libisosa (que no examina personalmente, por lo que desconoce la existencia de detalles como los orificios laterales) se vincula a Cigarralejo Sep. 478, así como al ejemplar de Hallstatt Sep. 995, y a los modelos itálicos de Tipo Berru en LTA o LTB2 (2016: 117 y 135 n.23), lo que llevaría la forja de esta pieza de Libisosa a un contexto más de dos siglos anterior al periodo sertoriano, al menos el s. IV a. C. Teniendo en cuenta la aparición en Iberia de otros cascos de una sola pieza de hierro y vinculados probablemente al universo más tardío de los Montefortino hispanos, caso del de la Sep. 11 de Castellones de Ceal en Jaén (Garcia Mauriño, 1993: 120) o de Toya (García Mauriño, 1993: 119), y el tipo de remate de Lezuza, creemos que se puede considerar una producción local, hispana, imitando modelos itálicos en bronce, y no necesariamente del s. IV a. C. sino mucho más tardía, puesto que los cascos legionarios de este periodo, e incluso del siglo anterior, eran casi universalmente de bronce (Junkelmann, 2000; Waurick, 1988; 1990). Pero esto es más una opinión que un dato demostrable. Lo que parece más seguro es que no sería nada probable que hacia el 75 a. C. un legionario romano recibiera un casco de hierro sin carrilleras y de kilo y medio de peso como parte de su equipo (ver Paddock, 1985 y 1993).

En último lugar, habría que realizar dos puntualizaciones (de cronología e "identidad" cultural) que se desprenden del contexto directo del casco. Su hallazgo en el interior de un hogar (posiblemente sacro) deja la puerta abierta a su depósito ritual, aunque su tesaurización o preservación (de un casco ya usado, con un golpe) no debería remontarse más allá de inicios del s. II a. C., cuando se erige la barriada, y perfectamente pudo ser contemporáneo a su amortización en el contexto de la destrucción sertoriana. Por otro lado, en el mismo espacio (dpto. 174) se recuperó el vaso figurado de la "crátera monomaquia", con unos extremos cronológicos similares, y en el que se representa claramente a los guerreros iberos con casco Montefortino sujetados por correas de barboquejo ${ }^{22}$.

La razón por la que todas las manillas de aletas de nuestro Grupo III (Quesada, 1997a: 498 ss.) pertenecen a escudos circulares, y no al escudo oval (thureos, scutum) en cualquiera de sus variedades y advocaciones celtas, itálicas, helenísticas, púnicas e hispanas, ha sido discutida ya por nosotros en bastante detalle, y no vamos a repetirla aquí (Quesada, 1997a: 530 y 535-536). La razón básica es que el escudo oval siempre lleva, en todos los ejemplares reales conocidos en cualquier cultura, desde Dinamarca a Egipto, una corta manilla horizontal con la sola y dudosa excepción del escudo de Doncaster. Del mismo modo, la inmensa mayoría de

22 Como ya se ha comentado, se trata de un caso excepcional, aunque no único en la iconografía vascular ibérica. De hecho, en otra pieza recuperada en Lezuza, la "tinaja de los caballeros", estos presentan carrilleras, no cintas (Uroz Rodríguez, 2012: 313-315; 2013: 54) 
las representaciones e imágenes, con rarísimas excepciones que se explican por la poca familiaridad del artista con la pieza real (caso por ejemplo de algunos detalles en la Columna Trajana, tan engañosa en los objetos representados), muestra la asociación escudo oval-manilla horizontal. ${ }^{23}$

La gran longitud de la manilla de Libisosa, y de otras ibéricas tan grandes o aún mayores hasta llegar a los $98 \mathrm{~cm}$ (El Cigarralejo, Sep. 135), solo implica que había escudos circulares ibéricos muy grandes, sobre todo a partir de principios del s. III a. C., y que el mantra de la caetra celtibérica del tamaño de un plato sopero o poco más no es sino un mito ${ }^{24}$. Caetras de $60 \mathrm{~cm}$ no eran en absoluto infrecuentes en el mundo ibérico, como también confirma la iconografía ${ }^{25}$. La manilla de Libisosa, perteneciente a un escudo de exactamente $78 \mathrm{~cm}$ de diámetro, no es tampoco la mayor conocida. Varias manillas de tipo IIIB y IIIC alcanzan dimensiones similares y mayores, y algunas otras tienen el mismo tipo de plegado del extremo que garantiza la precisión de la medida original. Así, en el primer grupo (manillas mayores de $78 \mathrm{~cm}$ sin plegado) contamos por ejemplo con la gran manilla del Cigarralejo 135, con $98 \mathrm{~cm}$ o Cigarralejo $136 \mathrm{de} 71 \mathrm{~cm}$, y Pozo Moro 4F-2 con $71 \mathrm{~cm}^{26}$. Y en el grupo de las manillas con plegado distal que dan un diámetro preciso, contamos, por ejemplo, con las manillas de las tumbas $1 \mathrm{y}$ 53 de La Serreta de Alcoi (Alicante) que tenían un diámetro de $66 \mathrm{~cm}$.

Como analizamos en su momento (Quesada, 1997a: 507, fig. 294) hay una tendencia hacia manillas cada vez mayores entre el s. IV y el II a. C., aunque no completamente definida ya que hay solapamientos. Un caso interesante es la aparición reciente de una manilla similar en tamaño y estructura a la de Lezuza en el complejo aristocrático de Cerro de la Merced, en Cabra (Córdoba), de unos $76 \mathrm{~cm}$ de diámetro y también con los extremos plegados. Embutido en un muro del vestíbulo, quizá con posible sentido apotropaico, puede datarse dentro del s. IV a. C., y no es posible llevarla más allá de finales del III a. C. en ningún caso. Porque lo cierto es que las manillas del tipo IIIB2, de gran tamaño suelen fecharse siempre en el s. IV a. C. (Torviscales de Fuente Tójar, Cigarralejo, Serreta, incluso Cerro de la Merced), y sin embargo la de Libisosa estaba en uso en la destrucción de $c .75$ a. C., ya que se encontró sobre el mismo pavimento de la calle 3, a diferencia de la mayoría de las armas excavadas. Dadas sus reparaciones, podría ser un arma antigua todavía activa. La perduración en uso durante décadas o incluso siglos de ciertas armas, modificadas, no es una rareza en piezas como buenas espadas a las que se cambiaba la empuñadura desde la Antigüedad Tardía, por ejemplo. Pero debemos aceptar la posibilidad de que el tipo siguiera fabricándose, sin apenas modificaciones, durante cerca de trescientos años.

Una de las novedades más importantes que aporta el conjunto armamentístico de Lezuza es el lote, muy significativo por lo infrecuente del tipo, y por su excelente contexto cronológico, de umbos bivalvos. Piezas de este tipo se habían localizado en varios yacimientos

23 En el caso de Iberia, la única excepción es la caja cineraria de piedra de Arjona (Jaén), sobre cuyas imágenes tenemos algunas reservas.

24 Argumentación detallada en Quesada, 1997a: 528-531, ampliada para los exvotos de bronce con escudo en Quesada, 2018: 414-418; y para los guerreros galaicos de granito en Quesada, 2003: 93-98.

25 Aun estando claramente mediatizados por la perspectiva (la proporción de las patas de los caballos respecto al resto del cuerpo), véase, sin ir más lejos, los enormes escudos circulares que portan los jinetes de la "tinaja de los caballeros" recuperada en el mismo contexto de destrucción sertoriana del sector 3 de Libisosa (Uroz Rodríguez, 2012: 313-315; 2013: 54, 57). En cambio, la caetra colgada del costado del caballo del jinete del "vaso de la muerte mítica" recuperado en el edificio oligárquico del sector 18 (dpto. 127), tiene un tamaño mucho más reducido (Uroz Rodríguez, 2012: 316 317; 2013: 58-59), como la que empuña el infante que se enfrenta al jinete de la "crátera de la monomaquia" del dpto. 174 (Uroz Rodríguez, 2012: 317-321; 2013: 58-59).

26 El primer tamaño no es desmesurado ni imposible. El aspis hoplita medía rutinariamente más de $90 \mathrm{~cm}$ de diámetro y, aunque era más pesado, se podía apoyar en el hombro. Escudos galos o germanos conservados han alcanzado diámetros superiores a los $100 \mathrm{~cm}$, caso del recientemente restaurado escudo germano tardío de Halle, de $130 \mathrm{~cm}$ de diámetro. 
hispanos antes de 1995 (Villaricos, Pozo, Moro, Cigarralejo, Arcos de la Frontera). El primer y breve análisis de conjuntos de estas piezas, que hicimos en 1997 (Quesada, 1997a: 539540) evidenciaba nuestra cierta perplejidad sobre el horizonte cronológico de estos umbos. Esa perplejidad era recogida en la tesis de G. García Jiménez, que dirigimos nosotros (García Jiménez, 2012: 203 ss.), que planteaba nuevas alternativas sobre estas piezas, y que distinguía además dos variantes en España. La primera, en la que las dos partes o conchas son idénticas y simétricas, y presentan un reborde para flanquear la spina en la parte superior del umbo de madera propiamente dicho; la segunda, en la que las dos piezas no son simétricas, sino que una tiene un reborde ondulado que cubriría la spina y luego se ajustaría con la otra pieza: es el caso de las piezas de Pozo Moro, Hinojal o Romazal Sep. 147. La primera variante es quizá la más sencilla y antigua (García Jiménez y Quesada, 2014). La pieza que nos ocupa, con un reborde angular para la spina, no tiene la prolongación cubre-spina, pero su pareja perdida podría haberla tenido.

En el ámbito celta los umbos bivalvos de diversos tipos se consideran normalmente antiguos o muy antiguos, de entre el s. V a. C. y - como muy tarde- principios del III a. C. (cf. Rapin, 1999: 46-47; 2001b; Baray, 2014: 31-36) ${ }^{27}$. Así, los ejemplares hispanos se consideraron desde Francia, por mímesis, como muy antiguos, forzando incluso una datación en el s. V a. C. (Rapin, 2001b: 281, fig. 5; Baray, 2014: 31 ss.), fecha que tampoco era permisible para el caso de los ejemplares más antiguos posibles, de las Seps. 395 y 483 del Cigarralejo, datadas dentro de un ya avanzado s. IV a. C. por asociación a fíbulas de La Tène I. Con todo, en un principio, las únicas fechas aparentemente sólidas del Cigarralejo nos llevaron a aceptar una fecha dentro del s. IV a. C. para estas piezas, y así lo indicamos inicialmente (Quesada, 2002-2003: 77-78). Sin embargo, nuestra impresión latente era que en otros contextos (Arcos de la Frontera, Pozo Moro) eran mucho más tardías, con asociaciones a cascos Montefortino y gladii hispanienses. Y, en efecto, hallazgos posteriores, junto con el reestudio del lote del Hinojal en Arcos de la Frontera y el de la tumba 4F-2 de Pozo Moro (Alcalá-Zamora, 2003), nos han llevado a considerar estos umbos como muy tardíos, y separados de la corriente antigua del ámbito galo o céltico europeo, con la que sin embargo debe haber algún enlace todavía ignoto de transmisión formal, quizá a través de las tumbas del Cigarralejo, cuya datación en el s. IV tampoco es indudable, aunque si plausible (García Jiménez y Quesada, 2014). Las dos piezas de la necrópolis extremeña del Romazal, recientemente publicada por completo, entran claramente en una fecha del s. II a. C. (García Jiménez y Quesada, 2014: 24-25; Hernández y Martín, 2017: fig. 67 - Sep. 126- y fig. 74 —Sep. 143—; y pp. 214-215). De hecho, los materiales del Romazal (puñales bidiscoidales, umbos bivalvos, lanzas, espada, espuelas) son muy próximos en conjunto a los de Libisosa, y del mismo entorno cronológico. Además, parece que en la Caridad de Camnireal (Teruel) se ha encontrado otro umbo de este tipo, todavía inédito (ref. en García Jiménez, 2016: 103, n. 48; Vicente y Ezquerra, e. p.: fig. 22, n. 14).

En este contexto, conviene llamar la atención sobre algo que nos recuerda nuestro colega G. García Jiménez sobre una serie de monedas púnicas de Cartago Nova, de finales del s. III a. C., que muestran en reverso unas proas de barco protegidas por escudos ovales con unos umbos con aletas que replican claramente el perfil del que nos ocupa (García Jiménez y Pérez, 2015: 170, n. 24 con refs.; Gómez de Caso, 2013: 14). Pero quizá lo más llamativo en los últimos años, junto con lo que ahora publicamos, es el hallazgo arqueológico (Ferber, 2014: 19) en la localidad de Décines y en un contexto ritual, de un umbo bivalvo de scutum probablemente romano capturado. Para Ferber (2014: 16 y passim) esta arma, junto con un claro gladius hispaniensis y otros objetos metálicos, debieron ser piezas romanas capturadas depositadas junto

27 Vid. crítica a este último en relación con estos umbos en García Jiménez y Pérez, 2015: 170. 
con restos humanos en el foso perimetral de un trofeo erigido por los allobroges en fechas de la primera mitad del s. I a. C. Esta pieza en territorio galo replica, con todos sus detalles, el modelo bivalvo hispano del s. II-I a. C., incluyendo el que «deux rivets maintiennent les deux parties assemblées sur la pina, mais aucune trace de fixation (rivet ou trace de rivet) n'a été observée permettant d'assurer le maintien de la pièce sur le plat du bouclier lui-même» (p. 17). Esto nos lleva hasta el punto de pensar, incluso, en su procedencia. De hecho, los rasgos más llamativos de esta pieza (galo)romana son su gran tamaño, casi $40 \mathrm{~cm}$ de longitud; su reborde cubre-spina fosilizado desde el modelo bivalvo; y sus aletas muy desarrolladas, mucho más que en los modelos españoles conocidos... salvo por un nuevo medio umbo del tipo bivalvo (inédito y resultado de un proceso judicial en la meseta oriental), que presenta el mismo tipo de aletas hipertrofiadas y un tamaño muy grande. De ahí al perfil de algunos umbos romanos monocascos del s. I (Poux, 2008: 344-345 y 410; García Jiménez y Quesada, 2014: 26, fig. 2B) hay un paso que puede - o no- darse. No es este el lugar de debatirlo.

En este panorama que hemos descrito, los tres umbos bivalvos de Lezuza, dos del s. II a. C. y uno de $c .75$ a. C. (aunque puede ser una perduración) vienen a confirmar la cronología tardía para estas armas que veníamos sugiriendo (García Jiménez y Quesada, 2014) y añaden un lote muy relevante al repertorio, que enlaza plenamente además con un contexto ya romano o de conquista romana. Si se admite como firme la cronología en el s. IV de las piezas del Cigarralejo, entonces sería una pieza de larga perduración, pero el panorama creciente nos lleva a pensar que, por esta y otras razones, convendría quizá revisar la cronología de muchas tumbas del Ibérico Pleno en ciertas necrópolis del Sureste cuya atribución cronológica descansa en la presencia de piezas áticas o de fíbulas antiguas en sus ajuares, sin considerar la posibilidad, demostrada en ya bastantes casos, de largas perduraciones (como ya planteamos nada menos que en 1992 pero con demasiada timidez: Sánchez y Quesada, 1992: 363-364 y coloquio en p. 666c) y que ha reforzado nuestro colega y amigo J. M. Gacía Cano (1999).

\section{ArReos de CABALlo y ESPUELAS}

Es llamativa la ausencia de bocados de caballo de cualquier tipo, de embocadura articulada, o modelos con desveno muy propios de un contexto republicano romano y bien documentados en otros yacimientos peninsulares. En cambio, sí se documentan dos elementos aislados (y separados por tres generaciones o unos 70 años) de cabezadas de caballo rígidas, muy raras en el mundo itálico, pero perfectamente documentadas en contextos peninsulares prerromanos desde el s. IV a. C. al menos, tanto en la meseta como en Lusitania o el mundo ibérico propiamente dicho. Es, en efecto, un tipo característicamente hispano, siempre de hierro (Quesada, 2005: fig. 21) y tradicionalmente fechado entre los siglos V-IV a. C., aunque sin duda perdura hasta el s. I a. C. en la península ibérica. De hecho, un ejemplar muy próximo al de Lezuza en forma y tamaño apareció en Renieblas, en Numancia (Luik, 2002: abb. 194, n1. 228). Schüle (1969: abb. 13) recogió un ejemplar completo broncíneo conservado en el RGZM, procedente al parecer de Italia (¿?) que luego ha sido objeto de discusión (Quesada, 2005: 29, fig. 24; Naso, 2003: 174-175, tav. 83; Graells, 2014: 76 y fig. 221). Al estar completo no queda duda sobre su función, aunque es cierto que la carrillera rígida presenta el orificio para ahogadero en una posición mucho más asimétrica, próxima a la nuquera, de lo que es habitual en ejemplares hispanos de hierro, donde suele estar centrada.

Es muy notable la abundancia de espuelas, seis de ellas datables en el siglo II a. C., de tipos ibéricos tradicionales, en general de modelo tardío, y uno solo de tipo céltico asociado a menudo al mundo romano, en el s. I a. C. Las espuelas son una rareza en contextos de necrópolis, 
pero aparecen con relativa abundancia en poblado, ya desde el s. IV a. C. (La Bastida) hasta el III-II a. C. (La Serreta de Alcoi) y más allá.

Las espuelas parecen surgir en el Mediterráneo en el s. V a. C., y ya hay referencias literarias en Grecia desde antes de 430 a. C. (Quesada, 2005: 34-35 con refs.). En el mundo ibérico se documentan con seguridad desde las primeras décadas del s. IV a. C., con variantes (raras) articuladas (Cuadrado, 1979; Quesada, 2001-2002) y rígidas, mucho más frecuentes. Las espuelas rígidas, generalizadas en Grecia, Italia, mundo céltico e ibérico, tienen rasgos comunes y variantes regionales acusadas que, en ocasiones, permiten agrupar por variantes y cronologías, aunque queda mucho trabajo por hacer. Lo fundamental es la forma en que el cuerpo rígido y curvo, pensado para ajustarse al tobillo, recibe las correas de sujeción. Mediante (a) gancho, (b) fenestra o ventana para pasar la correa, y (c) con la correa remachada (Quesada, 2005: fig. 29). La inmensa mayoría de las espuelas peninsulares, tanto las propiamente ibéricas como las de tipología romana, pertenecen a la segunda variedad, fenestrada. La forma del cuerpo, y la de la ventana (rectangular, circular, etc.) y otros detalles permite generar tipos y variantes. Aunque existen muchas publicaciones parciales de lotes de espuelas hispanas (eg. Cuadrado, 1979; Pérez Mínguez, 1992; Quesada, 2001-2002; Ruiz Vélez, 2007) y se pueden espigar lotes importantes en publicaciones generales sobre yacimientos ibéricos, como Coimbra del Barranco Ancho (García Cano, 1997: 219-220), o romanos como Cáceres el Viejo (Ulbert, 1984) o Numancia (Luik, 2002), sobre las piezas peninsulares solo se ha publicado un resumen, aun denso (Quesada, 2005), de una sistematización global que verá la luz próximamente, y que emplearemos mientras llega la publicación completa.

Casi todas las espuelas encontradas en Libisosa (siete en total, una cifra comparativamente muy elevada) son de tipo rígido y fenestradas, aunque de subtipos y variantes diferentes como se verá. Solo una, claramente romana, es de remache de botón, la única fechable a principios del s. I a. C., y pertenece a una tradición cultural el resto, que son todas hispanas. Estas espuelas rígidas en bronce, que suponen uno de los tres modelos de sujeción que antes hemos comentado (Quesada, 2005: 34 y fig. 29, de gancho, botón y fenestra) fueron ya catalogadas por Dechelette (1927: 708-710 y fig. 514) como galas o celtas, extendiéndose por toda Europa central. Sin embargo, el modelo céltico que se puede remontar a Le Tène I, es más pequeño, menos abierto y con un acicate más desarrollado que el de Lezuza. Sin embargo, estas espuelas evolucionaron hacia modelos que en el s. I a. C. usaba la caballería gala auxiliar de César, y que luego acabarían empleando los jinetes legionarios romanos del Alto Imperio. Es el caso de las espuelas de Alesia, del 52 a. C., cuyas espuelas grandes y abiertas, con acicate de bronce pequeño y a veces moldurado, se aproximan mucho a la pieza de Lezuza (e. g. Poux, 2008: 387 y fig. 61), o la de La Cloche, también del s. I a. C. (Chabot y Feugère, 1993: 344). En la consideración de Poux, basándose además en una referencia cesariana (Bell. Gal. 8,7,10) son propias de jinetes nobles que eventualmente se alían con Roma; no son un utensilio habitual ni siquiera en el s. I a. C. En Francia, este tipo de espuela de botones se asocia sobre todo a contextos del s. I a. C., lo que casa bien con el ejemplar libisosano, cuyo origen debe ser romano o asociado a ellos. Esto cuadra, de hecho, con que en un contexto del s. II a. C. como es Numancia, donde hay bastantes espuelas, estas sean de otros tipos (en particular el tipo Kobarid, que también aparece en Caminreal en época sertoriana) y el de botón "galo" no esté presente (Luik, 2002: 92-93, abb. 54 y 55). El tipo de botón perdura en cambio en Europa entre el s. I a. C. y el II d. C.; es, por ejemplo, muy frecuente en la actual Bulgaria (Torbov, 1998); y varias piezas del tipo, incluso con las palmetas centrales decorativas, se conocen en Britannia (Shortt, 1959: 64, fig. 3), en contexto ya imperial. Incluso dos ejemplares del santuario de Olimpia proceden de un contexto romano en el muro sur del estadio (Baitinger, 2004: 353 ss.). 
El conjunto de Libisosa, por su número, variedad y por su aportación a la serie de Knopfsporen tardías, es, pues, una muy importante contribución a las series de espuelas de la Edad de Hierro en Iberia/Hispania. Igualmente, y aunque la jáquima o hackamore rígida broncínea de Lezuza está incompleta, y no se asocie directamente a un bocado, es una pieza romana interesante que está entre las más antiguas del tipo, que alcanza su máximo desarrollo en el s. I d. C. Por último, las posibles fáleras ecuestres confirmarían la importancia del caballo en los contextos cerrados libisosanos iberorromanos del s. II al primer cuarto del I a. C.

\section{REFLEXIONES FINALES}

Es infrecuente encontrar grandes conjuntos de armas en contextos de poblado (Quesada, 2010). Lo habitual es hallarlas sobre todo en necrópolis y en campos de batalla y campamentos militares de la conquista romana. Cuando aparecen conjuntos importantes y coherentes en contextos de habitación indígena, como en Caminreal (Teruel) o Cabeça de Vaiamonte (Portugal), ambos del s. I a. C., tendemos a creer que se trata de lugares donde se asentó una guarnición romana ordinaria o para invernar, al modo de los "billetes" de época moderna y contemporánea, prácticas romanas ambas no necesariamente campamentales, pero más comunes de lo que suele creerse (Ñaco, 2001). Cadiou (2008: 350 ss.) disiente de la vieja opinión de Knapp sobre la habitual presencia de guarniciones en centros urbanos hispanos fuera del contexto invernal, pero la acepta en ocasiones, y también la presencia de guarniciones en invierno (Cadiou, 2008: 357-361 y 364-369). De hecho, sabemos que en 82 a. C. Sertorio se hizo popular porque evitó las guarniciones intraurbanas (Plutarco, Sert. 6,8) y creó castra hiberna aparte, evitando problemas como el de Castulo (Sert. 3,3) años antes, lo que indica que la práctica contraria era habitual. En este contexto, cabe pensar que la abundante presencia de armas completas de tipo romano en los dos niveles de ocupación que estudiamos en Libisosa pueda deberse a un fenómeno de este tipo, como ya se ha avanzado en repetidas ocasiones (por ejemplo: Uroz Rodríguez y Uroz Sáez, 2014: 214-215; Uroz Rodríguez, 2015: 205-206; Uroz Sáez y Uroz Rodríguez, 2016: 167-170), combinado, eso sí, en el caso del nivel sertoriano, con un asalto (con oposición militar) y destrucción. Esto no significa que todo el contingente fuera romano o latino, dado que auxilia locales podrían compartir buena parte del armamento. Sin embargo, el conjunto (casco, umbos, pila, etc.) nos lleva a pensar en un fuerte componente al menos muy romanizado.

La posición estratégica de Libisosa resultaba clave para asegurar el tránsito ya fuese de las legiones romanas como de los correos y mercancías. Y, a su vez, existen otros elementos del registro material excepcionalmente numerosos (y que se acrecientan en cada campaña de excavación) que podrían considerarse también como fósil director del agente militar romano. Desde luego, destaca el numeroso repertorio de vajilla de bronce tardorrepublicana, con una variedad formal que trasciende el común de objetos recuperados en suelo hispano (Uroz Rodríguez, 2015; e. p. a y e. p. b). Independientemente de su utilidad para el servicio del vino, su envase, medida, mezcla o filtración, o con la higiene personal en el contexto del simposio, su presencia, ya sea en asentamientos ibéricos tardíos como en campamentos militares, se ha venido considerando como una suerte de guía de la penetración de los ejércitos republicanos en el primer tercio del s. I a. C. (Mansel, 2004). A todo ello podríamos incluir, posiblemente, las imitaciones locales de formas de la vajilla de barniz negro, igualmente numerosas en el barrio iberorromano (Uroz Rodríguez et alii, e. p. a y e. p. b; Uroz Rodríguez, e. p. a y e. p. b; Uroz Rodríguez, 2012; Uroz Rodríguez y Uroz Sáez, 2014), y ponerlas en relación con la tesis, aun en continua revisión, que las relaciona con (re)producciones encargadas por y para el ejército 
romano (Adroher, 2014). Lo importante, en este sentido, es que tanto la vajilla de bronce como las imitaciones y una parte de la militaria ya estaban allí, no pueden tomarse como huellas de la destrucción.

Recapitulando, hasta ahora se han catalogado más de una treintena de armas, una de ellas desechada como tal. En general, se encuentran en excelente estado de conservación, y se agrupan en los distintos niveles cronológicos y funcionales de la que hemos ido desarrollando a lo largo de este trabajo y se resumen en la tabla incluida al principio.

Aunque hemos mantenido la distinción entre los dos grandes periodos de la destrucción y límite de los contextos cerrados (tercer cuarto del s. II a. C., coincidiendo con las guerras lusitanas y celtibéricas; y guerras sertorianas), lo cierto es que el número de armas en cada periodo es el mismo (16 y 16). Aunque hay cierta desproporción en los tipos de armamento que aparecen (la mayoría de las espuelas data del s. II, todos los pila son sertorianos y todos los puñales del s II a. C., etc.) lo cierto es que el número de piezas es demasiado exiguo como para intentar siquiera un análisis estadístico. La impresión, eso sí, es que los tipos de armas son básicamente los mismos: espadas rectas y umbos son del mismo tipo en ambos momentos, quizá algo evolucionado en la espada de $c .75$ a. C., pero la sensación - muy marcada- es que el conjunto del s. I a. C. es más "romano" (espuela de botones, espada recta, pila de lengüeta y de cubo, hackamore, bolaño) que el del s. II a. C., que tiene un aire más ibérico, aunque muy evolucionado (puñales, espuelas).

Al mismo tiempo, resultan tan llamativas las ausencias como las presencias, en particular las de glandes de honda, pila catapultaria, y la escasez de puntas de flecha en el contexto de c. 75 a. C., incluso la ausencia de clavi caligares, ya presentes en Baecula a fines del s. III a. C. Sospechamos que futuras intervenciones en las laderas exteriores del oppidum podrían proporcionar más materiales de este tipo. En todo caso, y pese al elevado número en términos absolutos del conjunto, debemos remarcar que el porcentaje excavado del yacimiento es todavía muy reducido.

No es este el lugar para desarrollar un análisis microespacial de los hallazgos de armas, pero algunos patrones quedan claros: la fase de ataque y destrucción en época sertoriana viene marcada por el hallazgo de armas (y de al menos un cadáver) en las calles. En cambio, en el s. II a. C. la abundancia de armas, incluyendo piezas de prestigio, en el lugar de culto (dpto. 176), es sin duda significativa y muestra una muy marcada concentración, que quizá distorsiona las diferencias que deberían darse entre las dos fases analizadas. Por ejemplo, cinco de las seis espuelas de la fase del s. II a. C. proceden de este edificio, lo que sin duda tiene significado y sobrepasa lo habitual en oppida ibéricos antiguos como, por ejemplo, La Bastida de Mogente (fines del s. IV a. C.), donde las espuelas y arreos de caballo se distribuyen por las diferentes viviendas con cierta regularidad (Quesada, 2011: 213, fig. 19).

Por otro lado, en varias ocasiones hemos discutido desde diferentes ópticas y perspectivas el espinoso problema de la atribución de las armas halladas en un yacimiento, sea un campo de batalla o un poblado, a un contendiente o a un individuo de una cultura concreta, y no es cuestión de repetir toda la argumentación que ha planeado siempre sobre las páginas precedentes ${ }^{28}$. Pero en el caso de Lezuza, aun partiendo de la base de que la mayoría de las armas deben ser producción local, y derivan de modelos de larga tradición ibérica o celtibérica, la presencia conjunta (aunque no asociación cerrada) de pila de lengüeta, gladius hispaniensis, casco Montefortino, umbo bivalvo de scutum, bolaños de artillería y alguna espuela de tipo

28 Quesada 2006; 2007; 2008; Quesada et alii, 2015: 317-319; y, en último lugar, una síntesis en Quesada, 2019 : 409-413. 
galo/romano, nos lleva a pensar en una presencia militar legionaria directa en Libisosa, ya en el s. II a. C. y, desde luego, a principios del I a. C.

En conjunto, el repertorio de armas de Libisosa que ahora publicamos se convierte, por derecho propio, en uno de los más importantes de la península ibérica para el periodo republicano avanzado, entre las guerras celtibéricas y las sertorianas (c. 150-c. 75 a. C.). Y lo es por el amplio número de piezas, por la excelente conservación de la mayoría de las armas que permite una muy adecuada clasificación en detalle; y por la variedad de tipos, que constituye un repertorio muy variado, quizá el más completo para este periodo en toda Iberia. Y, sobre todo, por la precisión del contexto arqueológico, fruto de una excavación actual con todos los requisitos modernos de atención al detalle, que ha permitido entre otras cosas distinguir dos fases relevantes y separadas en el tiempo por pocas décadas. Por todo ello, las armas de Lezuza encuentran un lugar relevante en la investigación del armamento republicano tardío de Iberia al mismo nivel - o incluso por encima en lo contextual - que conjuntos tan importantes (a escala incluso mediterránea) como los de Numancia, Cáceres el Viejo, Valentia, Caminreal, la Azucarera u Osuna. Y todo hace pensar que seguirá aportando, en los años venideros, más objetos (o/y contextos) que amplíen y contribuyan a la comprensión del presente catálogo.

\section{BIBLIOGRAFÍA}

Adroher, A. M. (2014): «Cerámica Gris Bruñida Republicana (GBR): el problema de las imitaciones en ceramología arqueológica», R. Morais, A. Fernández y M. J. Sousa (eds.), Monografias Ex Officina Hispana II. As Produções cerâmicas de imitação na Hispania. Porto, Faculdade de Letras da Universidade do Porto, tomo II: 281-290.

Alapont Martín, L.; Calvo, M. y Ribera i Lacomba, A. (2010): La destrucción de Valencia por Pompeyo (75 a.C.). Valencia, Ajuntament de València, Quaderns de difusió arqueològica, 6.

Alcalá-Zamora, L. (2003): La necrópolis ibérica de Pozo Moro. Madrid, Real Academia de la Historia, Bibliotheca Archaeologica Hispana, 23.

Alonso Sánchez, M. A. (1991): «Apliques ornamentales de la caballería romana». Cuadernos de Prehistoria y Arqueología, 18: 261-274. https://doi.org/10.15366/cupauam1991.18.011

Álvarez Arza, R. y Cubero Argente, M. (1999): «Los pila del poblado ibérico de Castellruf». Gladius, 19: 121-142. https://doi.org/10.3989/gladius.1999.16

Anderson, J. K. (1961): Ancient Greek Horsemanship. Berkeley, University of California Press.

Appels, A. y Laycock, S. (2007): Roman buckles and military fittings. Witham, Greenlight Publ.

Argente Oliver, J. L.; Díaz, A. y Bescos, A. (2001): Tiermes V. Carratiermes. Necrópolis celtibérica. Campañas 1977 y 1986-1991. Valladolid, Junta de Castilla y León, Arqueología en Castilla y León, 9.

Baitinger, H. (2004): «Hellenistisch-frühkaiserteitliche Reitersporen aus dem Zeusheiligtum von Olympia». Germania, 82: 351-380.

Baray, L. (2014): Ler mercenaires celtes et la culture de La Tène. Critéres archéologiques et positions sociologiques. Dijon, Eds. Universitaires.

Bishop, M. C. (1988): «Cavalry equipment of the Roman army in the first century AD», J. C. Coulston (ed.), Military Equipment and the Identity of Roman Soldiers. Oxford, BAR. Int. Series, 394: 67-196.

Bishop, M. C. (2016): The Gladius. The Roman short sword. Weapon, 51, Oxford, Osprey.

Bishop, M. C. (2017): The pilum. The Roman Heavy Javelin. Weapon, 55, Oxford, Osprey.

Ble Gimeno, E. (2015): Guerra y conflicto en el nordeste de Hispania durante el periodo romano republicano (218-45 a.C.). La presencia del ejército romano a partir de sus evidencias arqueológicas. Tesis Doctoral Universitat de Barcelona, Dirs. J. Noguera y F.X. Hernández Cardona, Barcelona.

Bonacina, L. (2007): «Il pilum: riconsiderazioni sul suo uso e la sua costruzione». Vexillum. Giornale della Società Italiana per gli Studi Militari Antichi, 1: 35-43.

Cadiou, F. (2008): Hibera in terra miles. Les armées romaines et la conquête de l'Hispanie sous la République (218-45 av. J._C.). Madrid, Casa de Velázquez. 
Campbell, D. B. (2003): Greek and Roman Artillery 399 BC-AD 363. London, Osprey, New Vanguard, 89.

Chabot, L. y Feugère, M. (1993): «Les armes de l'oppidum de la Cloche (B. du Rh.) et la destruction du site au Ier siècle avant notre ère». Documents d'Archéologie Méridionale, 16: 337-351. https:// doi.org/10.3406/dam.1993.1108

Coarelli, F. (1976): «Un elmo con iscrizione latina arcaica al museo di Cremona». L'Italie préromaine et la Rome républicaine I. Mélanges offerts à J. Heurgon, Rome: École Française de Rome: 157-179.

Connolly, P. (1997): «Pilum, gladius and Pugio in the Late Republic», M. Feugère (ed.), L'équipement militaire et l'armement de la République. Oxford, JRMES, 8: 41-57.

Connolly, P. (2001-2002): «The pilum from Marius to Nero - a reconsideration of its development and function». Journal of Roman Military Equipment Studies, 12-13: 1-8.

Cuadrado Díaz, E. (1979): «Espuelas Ibéricas». XV Congreso Nacional de Arqueología Lugo, 1977, Zaragoza, Secretaría General de los Congresos Arqueológicos Nacionales: 735-740.

Cuadrado Díaz, E. (1989): La panoplia ibérica de "El Cigarralejo" (Mula, Murcia). Murcia, Servicio Regional de Patrimonio Histórico, Documentos. Serie Arqueología.

Davoli, P. y Miks, C. (2015): «A new "Roman" sword from Soknopaiou Nesos (El Fayyum, Egypt)». ISAW Papers (New York Univesity Institute for the Study of the Ancient World, 9, http://dlib.nyu. edu/awdl/isaw/isaw-papers/9/.

Dechelette, J. (1927): Manuel d'archéologie préhistorique et celtique. IV Second Age du Fer ou Epoque de La Tène. Paris, Picard.

De Miguel, M. P. y Uroz Rodríguez, H. (2017): «Muerte violenta infantil durante las Guerras Sertorianas en el oppidum iberorromano de Libisosa (Lezuza, Albacete)», M. Díaz-Zorita, J. Escudero Carrillo, I. López Flores, J. Lucena Romero, E. Mora Rosa y S. Robles Carrasco (eds.), Paleopatología y Bioarqueología, contextualizando el registro óseo (Actas del XIII Congreso Nacional de Paleopatología, Écija 2015). Sevilla, Asociación Profesional de Bioarqueología y Asociación Nacional de Paleopatología: 333-341.

De Pablo Martínez, R. (2010): «Los puñales de filos curvos en el Duero Medio y Alto Ebro. A propósito de los llamados tipos La Osera y Villanueva de Teba», F. Romero y C. Sanz Mínguez (eds.), De la Región Vaccea a la Arqueología Vaccea, Valladolid, Centro de Estudios Vacceos "Federico Wattenberg" de la Universidad de Valladolid: 363-396.

De Pablo Martínez, R. (2012): «El pugio: nuevos datos para el estudio de su origen». Gladius, 32: 4968. https://doi.org/10.3989/gladius.2012.0003

De Pablo Martínez, R. (2018): Armamento y guerra durante la Segunda Edad del Hierro en la Cuenca Central del Duero y el Alto Ebro: los puñales como armas y símbolos. Tesis Doctoral Universidad de Valladolid, dirigida por F. Romero Carnicero, Valladolid.

Ferber, E. (2014): «Le trophée de Décines en territoire allobroge. Un témoignage des pratiques guerrières gauloises». Archèopages. Archéologie et Société, 39: 16-21. https://doi.org/10.4000/archeopages. 534

Fernández Ibáñez, C. (2008): «Las dagas del ejército altoimperial en Hispania». Gladius, 28: 87-175. https://doi.org/10.3989/gladius.2008.194

Fernández Ibáñez, C.; Kavanagh de Prado, E. y Vega Avelaira, T. (2012): «Sobre el origen de la daga en el ejército de Roma. Apreciaciones desde el modelo bidiscoidal hispano». I Durii Regione Romanitas. Homenaje a Javier Cortés. Palencia-Santander, Diputación de Palencia e Instituto "Santuola" de Prehistoria y Arqueología: 201-209.

Feugère, M (1994): Casques antiques. Les visages de la guerre de Mycenes à fin de l'Empire Romain. Paris, Errance.

Garcés Estalló, I. (2007): «El empleo del ronzal caballar en el norte del Ebro durante la Edad del Hierro y la época ibérica». Gladius, 27: 67-84. https://doi.org/10.3989/gladius.2007.97

Garcés Estalló, I. y Graells Fabregat, R. (2011): «Ancient bronce horse muzzles of the Iberian Peninsula». Gladius, 31: 7-42. https://doi.org/10.3989/gladius.2011.0001

García Cano, J. M. (1997): Las necrópolis ibéricas de Coimbra del Barranco Ancho (Jumilla. Murcia). I. Las excavaciones y estudio analítico de los materiales. Murcia.

García Cano, J. M. (1999): «Un aspecto poco tratado en las necrópolis ibéricas. La perduración de objetos en los ajuares: el caso de Murcia», M. A. Valero (ed.), las Jornadas de Arqueología Ibérica en Castilla-La Mancha, Toledo, Consejería de Educación y Cultura de Castilla-La Mancha: 169-179. 
García-Dils, S. y Menéndez Argüin, A. R. (2006): «Punta de pilum hallada en las proximidades del yacimiento de "El Guijo" (Ecija, Sevilla)». Habis, 37: 247-252.

García Jiménez, G. (2006): Entre Iberos y Celtas: las espadas de tipo La Tène del Noreste de la Península Ibérica. Madrid, CSIC. Anejos de Gladius, 10.

García Jiménez, G. (2012): El armamento de influencia la Tène en la Península Ibérica (siglos V-I a.C.). Monographies Instrumentum, 43. Montagnac, Eds. M. Mergoil.

García Jiménez, G. (2016): «Panoplias hispánicas con armas de tipo La Tène: Las opciones de la periferia», R. Graells y D. Marzoli (eds.), Armas de la Hispania Prerromana-Waffen im Vorrömischen Hispanien. (Actas del Encuentro Armamento y Arqueología de la guerra en la Península Ibérica prerromana. Madrid, 2014). Mainz, RGZM Tagungen, 24: 79-108.

García Jiménez, G. y Pérez Rubio, A. (2015): «De dragones, cascos y soldados de fortuna en el Occidente antiguo. Acerca de dos obras recientes sobre el mercenariado galo e hispano». Gladius, 35: 159-180. https://doi.org/10.3989/gladius.2015.0009

García Jiménez, G. y Quesada Sanz, F. (2014): «Los umbos bivalvos de scuta en Iberia y la cuestión céltica», F. Burillo Mozota y M. Chordá Pérez (eds.), VII Simposio sobre los celtíberos. Nuevos Hallazgos, Nuevas Interpretaciones. Estudios Celtibéricos, 7. Teruel, Fundación Segeda-Centro de Estudios Celtibéricos: 21-27.

García Mauriño, J. (1993): «Los cascos de tipo Montefortino en la Península Ibérica. Aproximación al estudio del armamento en la Segunda Edad del Hierro». Complutum, 4: 95-146.

Gómez de Caso Zuriaga, J. (2013): «El ejército cartaginés en Iberia durante la Segunda Guerra Púnica». Desperta Ferro Antigua y medieval, 17: 10-15.

Grab, M. (2011): «Das marianische pilum. Der römische Mythos im Test», C. Koepfer y F. W. Himmler (eds.), Die römische Armee im Experiment. Berlin, Frank \& Timme: 83-92.

Graells Fabregat, R. (2014): Mistophoroi ex Iberias. Una aproximación al mercenariado hispano a partir de las evidencias arqueológicas (s. VI-IV a.C.). Venosa, Osanna Edizioni.

Graells Fabregat, R.; Lorrio Alvarado, A. J. y Quesada Sanz, F. (2014): Cascos hispano-calcídicos. Simbolo de las elites guerreras celtibéricas. Mainz, Katalogue Vor- und Frühgeschichtlicher Altertümer, 46.

Grau, I.; Olmos, R. y Perea, A. (2008): «La habitación sagrada de la ciudad ibérica de La Serreta». Archivo Español de Arqueología, 81: 5-29. https://doi.org/10.3989/aespa.2008.v81.38

Hernández Canchado, N. (2008): «La cerámica de importación tardorrepublicana del barrio iberorromano de Libisosa: el departamento 79». Verdolay, 11: 143-178.

Hernández Hernández, F. y Martín Bravo, A. M. (2017): Las necrópolis de El Romazal y el conjunto arqueológico de Villasviejas del Tamuja (Botija, Plasenzuela, Cáceres). Madrid, La Ergástula.

Horvat, J. (1997): «Roman Republican weapons from Smihel in Slovenia». L'équipement militaire et l'armement de la République. Oxford, JRMES, 8: 105-120.

Horvat, J. (2002): «The Hoard of Roman Republican Weapons from Grad near Smihel». Arheoloski Vestnik, 52: 117-192.

Hyland, A. (1990): Equus. The Horse in the Roman World. London, Batsford.

Iriarte Cortázar, A.; García, M. L.; Filloy, I.; Gil, E. y Sesma, J. (1996): «El depósito de armas de La Azucarera (Alfaro, La Rioja)». Cuadernos de Arqueología de la Universidad de Navarra, 4: 173-194.

Iriarte Cortázar, A.; Gil, E.; Filloy, I. y García, M. L. (1997): «A votive deposit of Republican weapons at Craccurris (Alfaro, La Rioja, Spain)». L'équipement militaire et l'armement de la République. Oxford, JRMES, 8: 233-250.

Istenic, J. (2000): «A late-republican gladius from the river Ljubljanica (Slovenia)». Journal of Roman Military Equipment Studies, 11: 1-9.

James, S. (2011): Rome \& the sword. How warriors and weapons shaped Roman history. London, Thames \& Hudson.

Junkelmann, M. (1992): Die Reiter Roms, Teil III: Zubehör, Reiweise, Bewaffnung. Mainz.

Junkelmann, M. (2000): Römische Helme. Sammlung Axel Guttmann. Mainz, Band VIII. Philipp vonz Zabern.

Kaiser Aguilar, J. M. (2003): «Puntas de flecha de la Edad del Bronce en la Península Ibérica. Producción, circulación y cronología». Complutum, 14: 73-106.

Kavanagh de Prado, E. (2008): «El puñal bidiscoidal peninsular: tipología y relación con el puñal militar romano (pugio)». Gladius, 28: 5-85. https://doi.org/10.3989/gladius.2008.193 
Kavanagh de Prado, E. (2016): «Algunos apuntes en torno a la adopción de armas hispánicas por el ejército de Roma», R. Graells y D. Marzoli (eds.), Armas de la Hispania Prerromana-Waffen im Vorrömischen Hispanien (Actas del Encuentro Armamento y Arqueología de la guerra en la Península Ibérica prerromana. Madrid, 2014). Mainz, RGZM Tagungen, 24: 149-163.

Kavanagh de Prado, E. y Quesada Sanz, F. (2009): «Pugio hispaniensis between Celtiberia and Rome, Current research and analysis of the construction of the sheaths». A. Morillo, N. Hanel y E. Martín Hernández (eds.), Limes XX. Estudios sobre la frontera romana. Madrid, CSIC/Polifemo, Anejos de Gladius, 13, I: 338-350.

Keppie, L. (1991): «A centurion of legio Martia at Padova?». Journal of Roman Military Equipment Studies, 2: 115-123.

Lawson, A. K. (1978): «Studien zum römischen Pferdegeschirr». Jahrbuch des Römisch-Germanisches Zentralmuseum, 25: 131-172.

Lejars, T. (2003): «Les fourreaux d'epee lateniens. Supports et ornementations», D. Vitali (ed.), L'immagine tra mondo celtico e mondo etrusco-italico. Aspetti della cultura figurativa nell'antichità. Bologna, Alma Mater Studiorum, Università de Bologna, Dipartimento di Archeologia, Studi e Scavi, 20: 9-70.

Littauer, M. A. (1969): «Bits and pieces». Antiquity, 43: 289-300. https://doi.org/10.1017/ s0003598x00040734

Lorrio Alvarado, A. J. y Sánchez de Prado, M. D. (2014): «El Molón (Camporrobles, Valencia) en los siglos II-I a.C.», F. Sala y J. Moratalla (eds.), Las Guerras Civiles romanas en Hispania. Una revisión histórica desde la Contestania. Alicante, Diputación Provincial-Universidad de Alicante: 249-269.

Luik, M. (2002): Die Funde aus den Römischen Lagern um Numantia im Römisch-Germanischen Zentralumuseum. Mainz, RGZM.

Mansel, K. (2004): «Vajilla de bronce en la Hispania republicana», R. Olmos y P. Rouillard (eds.), La vajilla ibérica en época helenística (siglos IV-III al cambio de era) (Actas del Seminario de la Casa de Velázquez, Madrid, 2001). Madrid, Casa de Velázquez: 19-30.

Marsden, E. W. (1969): Greek and Roman Artillery. Historical Development. Oxford, Clarendon Press.

Marsden, E.W. (1971): Greek and Roman Artillery. Technical Treatises. Oxford, Clarendon Press.

Mazzoli, M. (2016): «Elmi "Montefortino" nel Mediterraneo Occidentale». R. Graells i Fabregat y D. Marzoli (eds.), Armas de la Hispania prerromana. Mainz, RGZM-DAI: 109-147.

McDonnell-Staff, P. (2010): «The peg that would break. Marius and the pilum: a roman myth». Ancient Warfare, 5 (1): 34-36.

Miks, C. (2007): Studien zur Römischen Schwertbewaffnung in der Kaiserzeit. Rahden, Vrlg. Marie Leidorf, Kölner Studien zur Archäologie der Römischen Provinzen (KSARP), 8.

Murray, W. M. (2012): The Age of Titans. The rise and fall of the great hellenistic navies. Oxford, Oxford UP.

Naso, A. (2003): I Bronzi Etruschi e italici del Römisch-Germanisches Zantralmuseum. Mainz, RGZM, Kataloge vor-und Frühgeschichtlicher Altertümer, 33.

Noguera Guillén, J.; Ble Gimeno, E. y Valdés Matías, P. (2013): La Segona Guerra Púnica al nord-est d'Ibèria: una revisió necessària. Barcelona, Soc. Cat. d'Arqueologia.

Naco del Hoyo, T. (2001): «Milites in oppidis hibernabant. El hospitium militare invernal en ciudades peregrinas y los abusos de la hospitalidad sub tectis durante la República». Dialogues d'Histoire Ancienne, 27 (2): 63-90. https://doi.org/10.3406/dha.2001.2449

Olcina Doménech, M. (ed.) (2009): Lucentum. Tossal de Manises, Alicante. Arqueología e Historia. Alicante, Diputación.

Olcina Doménech, M.; Guilabert Mas, A. y Tendero Porras, E. (2010): «Lectura púnica del Tossal de Manises (Alicante)». Los púnicos en Iberia. Proyectos, revisiones, sintesis. Mainake, 32 (1): 229249.

Paddock, J. (1985): «Some changes in the manufacture and supply of Roman Helmets under the Late Republic and Early Empire», M. C. Bishop (ed.), The Production and Distribution of Roman Military Equipment. Oxford, BAR Int. Series, 275: 142-159.

Paddock, J. (1993): The Bronze Italian Helmet: the development of the cassis from the last quarter of the sixth century $B C$ to the third quarter of the first century $A D$. Unpublished $\mathrm{PhD}$ Thesis, University College London. http://discovery.ucl.ac.uk/1348999/ 
Pérez Mínguez, R. (1992): «Acicates ibéricos del Museo de Prehistoria de Valencia», Homenaje a E. Pla Ballester. Valencia, SIP, Trabajos Varios, 89: 215-220.

Pernet, L. (2010): Armement et auxiliaires gaulois (Ile et Ier siècles avant notre ère. Protohistoire européenne, $12^{\mathrm{a}}$ ed. Montagnac, Monique Mergoil.

Poux, M. (2008): «L'empreinte du militaire tardo-républicain dans les faciès mobiliers de La Tène finale», M. Poux (ed.), Sur les traces de César. Actes Table Ronde. Glux-en-Glenne, Bribacte, 14: 299-432.

Quesada Sanz, F. (1989): Armamento, Guerra y Sociedad en la necrópolis ibérica de "El Cabecico del Tesoro" (Murcia, España). Oxford, BAR Int. Series, 502, 2 vols.

Quesada Sanz, F. (1997a): El armamento ibérico. Estudio tipológico, geográfico, funcional, social y simbólico de las armas en la Cultura Ibérica (siglos VI-I a.C.). Montagnac, Ed. Monique Mergoil, Monographies Instrumentum, 3.

Quesada Sanz, F. (1997b): «Gladius hispaniensis: an archaeological view from Iberia», M. Feugère (ed.), L'équipement militaire et l'armement de la République. Oxford, Journal of Roman Military Equipment Studies, 8: 251-270.

Quesada Sanz, F. (1997c): «¿Qué hay en un nombre? La cuestión del gladius hispaniensis». Boletín de la Asociación Española de Amigos de la Arqueología, 37: 41-58.

Quesada Sanz, F. (2001-2002): «En torno a las espuelas articuladas ibéricas, artesanado y las relaciones entre las regiones murciana y granadina». Soliferreum. Studia E. Cuadrado. Anales de Prehistoria y Arqueología, 17-18: 239-246.

Quesada Sanz, F. (2002-2003): «Innovaciones de raíz helenística en el armamento y tácticas de los pueblos ibéricos desde el s. III a.C.», M. Bendala, P. Moret, F. Quesada (eds.), Formas e imágenes del poder... Cuadernos de Prehistoria y Arqueología de la Universidad Autónoma de Madrid, 2829: 69-94.

Quesada Sanz, F. (2003): «¿Espejos de piedra? Las imágenes de armas en las estatuas de los guerreros llamados galaicos». Madrider Mitteilungen, 44: 87-112.

Quesada Sanz, F. (2005): «El gobierno del caballo montado en la Antigüedad clásica con especial referencia al caso de Iberia. Bocados, espuelas y la cuestión de la silla de montar». Gladius, 25: 97-150. https://doi.org/10.3989/gladius.2005.26

Quesada Sanz, F. (2006): «Not so different: individual fighting techniques and small unit tactics of Roman and Iberian armies within the framework of warfare in the Hellenistic Age», P. Francois, P. Moret y S. Péré-Noguès (eds.), L'hellénisation en Méditerranée Occidentale au temps des guerres puniques (260-180 av. J.C.). (Actes Colloque Toulouse, 31 mars-2 avril 2005). Pallas, 70. Toulouse, Presses Universitaires du Mirail: 245-263.

Quesada Sanz, F. (2007): «Hispania y el ejército romano republicano. Interacción y adopción de tipos metálicos», C. Fernández (ed.), Metalistería en la Hispania Romana, Sautuola, 13: 379-401.

Quesada Sanz, F. (2008a): «Armamento romano e ibérico en Urso (Osuna): testimonio de una época». Cuadernos de los amigos de los Museos de Osuna, 10: 13-19.

Quesada Sanz, F. (2008b): Armas de Grecia y Roma. Madrid, La Esfera.

Quesada Sanz, F. (2011): «El armamento de un poblado ibérico del siglo IV a.C.: una oportunidad excepcional», H. Bonet y J. Vives-Ferrándiz (eds.), La Bastida de les Alcusses 1928-2010. Valencia, Museu de Prehistoria: 196-219.

Quesada Sanz, F. (2016): «Armamento ofensivo romano. De Augusto a Nerva», La Legión Romana (III). El primer siglo del Imperio. Madrid, Desperta Ferro Especial, X: 26-33.

Quesada Sanz, F. (2018): «Los varones y sus armas en los pequeños bronces ibéricos. Nuevas consideraciones sobre sus problemas y posibilidades de interpretación», L. Prados, C. Rueda Galán y A. Ruiz Rodríguez (eds.), Bronces ibéricos. Una historia por contar. Libro-Homenaje al Prof. G. Nicolini. Madrid-Jaén, UAM-UJA: 409-454.

Quesada Sanz, F. (2019): «La cultura material militar en Hispania», E. H. Sánchez López y M. Bustamante (eds.), Arqueología Romana en la Península Ibérica. Granada, Universidad de Granada: 409-427.

Quesada Sanz, F.; Gómez Cabeza, F.; Molinos Molinos, M. y Bellón Ruiz, J. P. (2015): «El armamento hallado en el campo de batalla de Las Albahacas-Baecula», J. P. Bellón, A. Ruiz, M. Molinos, C. Rueda y F. Gómez (eds.), La Segunda Guerra Púnica en la península ibérica. Baecula: arqueología de una batalla. Jaén, Universidad de Jaén: 311-396. 
Quesada Sanz, F. y Kavanagh de Prado, E. (en prensa): «El armamento de época romana republicana en Hispania», H. Uroz Rodríguez y A. Ribera (eds.), Cultura Material romana en la Hispania Republicana. Contextos privilegiados y estado de la cuestión.

Quesada Sanz, F.; Lechuga Chica, M. A.; Ruiz Rodríguez, A.; Molinos Molinos, M.; Rísquez Cuenca, C. y Gener Moret, M. (2019): «La primera cota de malla de hierro en la Península Ibérica en la Antigüedad: la tumba de Piquía (Arjona, Jaén)», B. Vallori, C. Rueda y J. P. Bellón (eds.), Accampamenti, guarnigioni e assedi durante la Seconda Guerra Punica e la conquista romana (secoli III-I a.C.): prospettive archeologiche. Roma, Quasar: 155-174.

Rabeisen, E. (1990): «La production d'equipement de cavalerie au 1er s. après J.C. à Alesia (AliseSante-Reine, Côte-d'Or, France)». Journal of Roman Military Equipment Studies, 1: 73-98.

Rapin, A. (1999): «L'armement celtique en Europe: chronologie de son evolution technologique du V $\mathrm{V}^{\mathrm{e}}$ au I ${ }^{\text {er }}$ s. av. J.-C.». Gladius, 19: 33-67. https://doi.org/10.3989/gladius.1999.13

Rapin, A. (2001a): «Des épées romaines dans la collection d'Alise-Sainte-Reine». Gladius, 21: 31-56. https://doi.org/10.3989/gladius.2001.79

Rapin, A. (2001b): «Un bouclier celtique dans la colonie grecque de Camarina (Sicile)». Germania, 79: 273-296.

Ribera i Lacomba, A. (1995): «La primera evidencia arqueológica de la destrucción de Valentia por Pompeyo». Journal of Roman Archaeology, 8: 19-40. https://doi.org/10.1017/s1047759400015956

Ribera i Lacomba, A. (2013): «La destrucció de Valentia per Pompeu (75 a.C.) i el problema del seu abandó», J. Vidal y B. Antela (eds.), Más allá de la batalla. La violencia contra la población. Zaragoza, Ed. Pórtico: 127-191.

Ribera i Lacomba, A. (2014): «La destrucción de Valentia (75 a.C.) y la cultura material de la época de Sertorio (82-75 a.C.)», F. Sala y J. Moratalla (eds.), Las Guerras Civiles romanas en Hispania. Una revisión histórica desde la Contestania. Alicante, Diputación Provincial-Universidad de Alicante: 65-77.

Rihll, T. (2007): The Catapult: a history. Yardley, Westholme Publishing.

Robinson, H. R. (1975): The Armour of Imperial Rome. London, Purnell.

Rouillard, P. (1997): Antiquités de l'Espagne. Paris, Musée du Louvre.

Ruiz Zapatero, G. (1983): Los Campos de Urnas del Nordeste de la Peninsula Ibérica. Tesis doctorales de la Universidad Complutense de Madrid, Madrid.

Ruiz Vélez, I. (2007): «Las espuelas y la caballería en la necrópolis de Villanueva de Teba (La Bureba, Burgos)». Boletín de la Institución Fernán González, 235: 311-336.

Saliola, M. y Casprini, F. (2012): Pugio-gladius brevis est. Oxford, Archaeopress, BAR Int. Series, 2404.

Sánchez Meseguer, J. L. y Quesada Sanz, F. (1992): «La necrópolis ibérica del Cabecico del Tesoro (Verdolay, Murcia)», J. Blánquez y V. Antona del Val (eds.), Congreso de Arqueología Ibérica: Las Necrópolis. Madrid, Departamento de Prehistoria y Arqueología, Universidad Autónoma de Madrid: 349-397.

Sandars, H. (1913): «The weapons of the Iberians». Archeologia, LXIV: 205-294. https://doi. org/10.1017/s0261340900010730

Sanmartí Grego, E. (1994): «Dos punyals celtibèrics procedents del poblat ibèric del Turó del Vent». Lauro, 6: 3-8.

Schüle, W. (1969): Die Meseta-Kulturen der Iberischen Halbinsel. 2 vols., Berlin, De Gruyter.

Scott, I. R. (1985): «First century military daggers and the manufacture and supply of weapons for the Roman Army», M. C. Bishop (ed.), The Production and Distributtion of Roman Military Equipment. Oxford, BAR Int. Series, 275: 160-213.

Shortt, H. de S. (1959): «A Provincial Roman spur from Longstock, Hants, and Other Spurs from Roman Britain». Antiquaries Journal, 39: 61-76. https://doi.org/10.1017/s000358150008361x

Sievers, S. (1997): «Alesia und Osuna: Bemerkungen zur Normierung der Spätrepublikanischen Bewaffnung und Ausrüstung». L'équipement militaire et l'armement de la République. Oxford, Journal of Roman Military Equipment Studies, 8, 271-276.

Simon Ortisi, C. (2003): Studien zum römischen Pferdegeschirr aus Pompeji, Herculaneum un denh Vesuvillen. Metallzäume, Trensesn und Kandaren. Inagural Dissertation zur Erlangung des Doktorgrader der Philpsophie an der Ludwig-Maximilians Universität München, München.

Stephenson, I. P. y Dixon, K. R. (2003): Roman Cavalry Equipment. Stroud, Sutton. 
Stiebel, G. D. (2004): «A Hellenistic gladius from Jericho», E. Netzer (ed.), Hasmonean and Herodian palaces at Jericho. Final Reports 1973-1987, II, Jerusalem, Israel Exploration Society: 229-232.

Taylor, A. K. (1975): «Römische Hackamoren und Kappzäume aus Metall». Jahrbuch des RömischGermanisches Zentralmuseum, 22: 106-133.

Torbov, N. (1998): «Spurs from the 2nd c. BC-1st c. AD found in North-Western Bulgaria». Archaeologia Bulgarica, 3: 54-63.

Ulbert, G. (1984): Cáceres el Viejo. Ein spätrepublikanisches Legionsläger in Spanisch-Extremadura. Mainz am Rheim, Madrider Beiträge, 11.

Uroz Rodríguez, H. (2012): Prácticas rituales, iconografia vascular y cultura material en Libisosa (Lezuza, Albacete). Nuevas aportaciones al Ibérico Final del Sudeste. Alicante, Universidad de Alicante.

Uroz Rodríguez, H. (2013): «Héroes, guerreros, caballeros, oligarcas: tres nuevos vasos singulares ibéricos procedentes de Libisosa». Archivo Español de Arqueología, 86: 51-73. https://doi.org/10.3989/ aespa.086.013.004

Uroz Rodríguez, H. (2015): «La vajilla de bronce romana tardorrepublicana de Libisosa». Madrider Mitteilungen, 56: 168-210.

Uroz Rodríguez, H. (2018): «Más que objetos rituales: un nuevo conjunto de vasos plásticos ibéricos». Saguntum, 50: 129-163. https://doi.org/10.7203/sagvntvm.50.10933

Uroz Rodríguez, H. (2020): «Libisosa: un "tesoro" para la investigación de Iberia e Hispania», A. Carretero y C. Papí (coords.), Actualidad de la investigación arqueológica en España I. Madrid, Ministerio de Cultura y Deporte-MAN: 29-44.

Uroz Rodríguez, H. (en prensa a): Libisosa. Historia congelada, Arqueología viva. Albacete, Instituto de Estudios Albacetenses.

Uroz Rodríguez, H. (en prensa b): «Libisosa como contexto privilegiado para el estudio de la cultura material romana republicana», H. Uroz Rodríguez y A. Ribera (eds.), Cultura Material romana en la Hispania Republicana. Contextos privilegiados y estado de la cuestión.

Uroz Rodríguez, H.; Ribera, A. y Hernández Canchado, N. (en prensa a): «Closed contexts in the destruction of the Iberian oppidum of Libisosa (Lezuza, Albacete-Spain) during the Sertorian War: import pottery», Exploring the Neighborhood: the Role of Ceramics in Understanding Place in the Hellenistic World.

Uroz Rodríguez, H.; Ribera, A. y Hernández Canchado, N. (en prensa b): «Cerámica romana republicana de Libisosa: novedades y aportaciones al estado de la cuestión», H. Uroz Rodríguez y A. Ribera (eds.), Cultura Material romana en la Hispania Republicana. Contextos privilegiados y estado de la cuestión.

Uroz Rodriguez, H. y Uroz Sáez, J. (2014): «La Libisosa iberorromana: un contexto cerrado de - y por- las guerras sertorianas», F. Sala y J. Moratalla (eds.), Las Guerras Civiles romanas en Hispania. Una revisión histórica desde la Contestania. Alicante, Diputación Provincial-Universidad de Alicante: 199-215.

Uroz Sáez, J. (2012): «La colonia romana de Libisosa y sus precedentes», G. Carrasco (ed.), La ciudad romana en Castilla-La Mancha. Cuenca, Universidad de Castilla-La Mancha: 87-130.

Uroz Sáez, J.; Molina Vidal, J.; Poveda Navarro, A. M. y Márquez Villora, J. C. (2004): «Aproximación al conjunto arqueológico y monumental de Libisosa (Cerro del Castillo, Lezuza, Albacete)». Investigaciones Arqueológicas en Castilla-La Mancha (1996-2002). Toledo, Junta de Comunidades de Castilla-La Mancha: 181-191.

Uroz Sáez, J.; Poveda Navarro, A. M. y Márquez Villora, J. C. (2003): «Libisosa. La transformación de un oppidum en colonia romana», A. M. Poveda y J. Uroz Sáez (eds.), La Iberia de los oppida ante su romanización. Homenaje a E. A. Llobregat Conesa (Actas del III Seminario de Historia, Elda 2003). Alebus, 13, Elda, Museo Arqueológico Municipal: 221-252.

Uroz Sáez, J.; Poveda Navarro, A. M. y Márquez Villora, J. C. (2006): «La puerta norte de Libisosa: cronología y arquitectura», Th. G. Schattner y F. Valdés (eds.), Puertas de ciudades. Tipo arquitectónico y forma artística (Actas del Coloquio Internacional, Toledo 2003). Toledo, Philipp von Zabern-Diputación Provincial de Toledo: 173-184.

Uroz Sáez, J. y Uroz Rodríguez, H. (2016): «La importancia de las vías de comunicación y Libisosa: ejército, comercio y romanización en su contexto arqueológico tardorrepublicano», G. Carrasco 
(coord.), Vias de comunicación romanas en Castilla-La Mancha. Cuenca, Universidad de CastillaLa Mancha: 151-176.

Vanden Berghe, L. y Simkins, M. (2001-2002): «Construction and reconstruction of the Titelberg dagger». Journal of Roman Military Equipment Studies, 12-13: 75-84.

Vicente Redón, J. D. y Ezquerra, B. (en prensa): «La cultura material de "La Caridad" (Caminreal, Teruel). Un análisis preliminar», H. Uroz Rodríguez y A. Ribera (eds.), Cultura Material romana en la Hispania Republicana. Contextos privilegiados y estado de la cuestión.

Vicente Redón, J. D.; Punter, M. P. y Ezquerra, B. (1997): «La catapulta tardo-republicana y otro equipamiento militar de "La Caridad" (Caminreal, Teruel)», M: Feugère (ed.), L'équipement militaire et l'armement de la République. Oxford, Journal of Roman Military Equipment Studies, 8: 167-199.

Walbank, F. W. (1957): A Historical commentary on Polybius. I, Oxford, Clarendon Press.

Waurick, G. (1988): «Römische Helme», Antike Helme. Mainz, Röm. Germ. Zentralmuseums Mainz: 327-364.

Waurick, G. (1990): Helme in Caesars Heer. Mainz, Röm. Germ. Zentralmuseums Mainz.

Wilkins, A. (2003): Roman Artillery. Shire Archaeology, 86, Princes Risborough, Bucs., Shire Publ.

Wilkins, A. (2017): Roman Imperial Artillery. Dumfries, Solway Print.

Williams, H. (1992): «A Hellenistic catapult washer from Sounion». Echos du monde classique: Classical Views, 36, n. s. 11: 182-187.

Recibido: $24-02-2020$

Aceptado: 02-08-2020 